FRANCISCO FERNANDO MACIEL FILHO

CONSTRUÇÃO DE CICLOS DE CONDUÇÃO PARA ESTIMATIVA DE EMISSÕES VEICULARES PARA ÔNIBUS URBANOS

Dissertação apresentada à Escola

Politécnica da Universidade de São

Paulo para obtenção do título de Mestre em Ciências 
FRANCISCO FERNANDO MACIEL FILHO

\section{CONSTRUÇÃO DE CICLOS DE CONDUÇÃO PARA ESTIMATIVA DE EMISSÕES VEICULARES PARA ÔNIBUS URBANOS}

Dissertação apresentada à Escola Politécnica da Universidade de São Paulo para obtenção do título de Mestre em Ciências

Área de concentração:

Engenharia de Transportes

Orientador: Prof. Dr. Orlando Strambi 


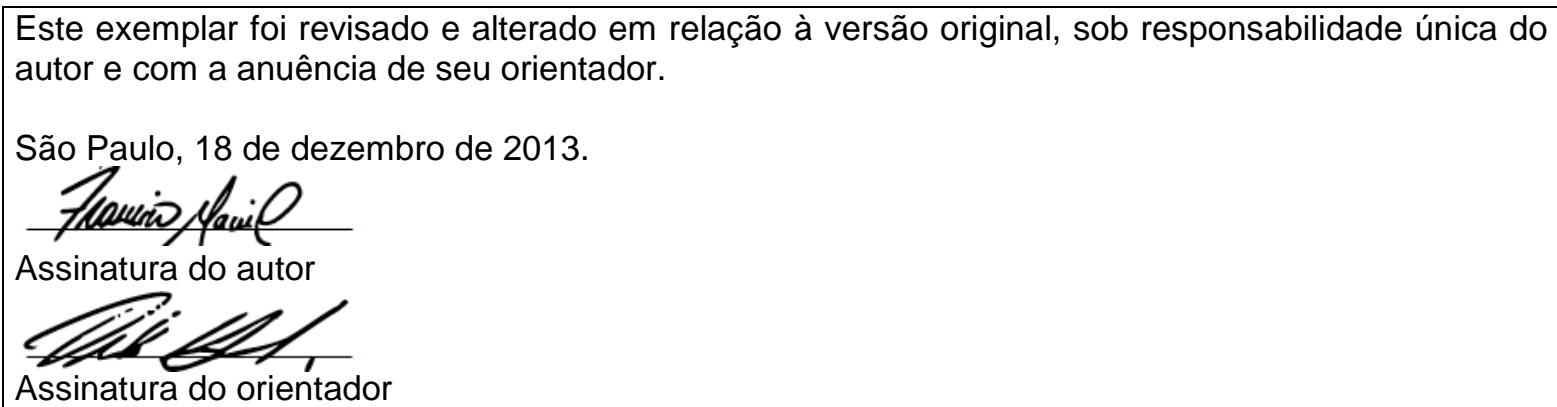

FICHA CATALOGRÁFICA

Maciel Filho, Francisco Fernando

Construção de ciclos de condução para estimativa de emissões veiculares para ônibus urbanos / F.F. Maciel Filho. versão corr. -- São Paulo, 2013.

$117 \mathrm{p}$.

Dissertação (Mestrado) - Escola Politécnica da Universidade de São Paulo. Departamento de Engenharia de Transportes.

1.Engenharia de transportes 2.Transportes (Planejamento; Operação) 3.Ciclos de condução 4.Estimativas de emissões I.Universidade de São Paulo. Escola Politécnica. Departamento de Engenharia de Transportes II.t. 


\section{DEDICATÓRIA}

Dedico este trabalho à minha esposa Débora

e a meus pais e irmãos. 


\section{AGRADECIMENTOS}

Aos meus pais pelo amor e incentivo contínuo à minha educação.

À minha esposa Débora pelo carinho, apoio e compreensão.

Aos colegas Athos Bernardes, pelo interesse e colaboração no desenvolvimento das complexas planilhas de aquisição e análise de dados, e Milton Shikishima, pela dedicação e empenho na instrumentação e acompanhamento do veículo de teste utilizado. Sem eles a realização desse trabalho não teria sido possível.

Ao Professor Dr. Orlando Strambi pela orientação e disponibilidade constantes.

À Mercedes-Benz do Brasil Ltda., nas pessoas do Dr. Daniel Spinelli, Marcos Argentino e Paschoal Federico Neto, por permitirem e apoiarem a realização deste trabalho.

Ao CNPq pelo apoio à pesquisa. 


\section{RESUMO}

O objetivo principal deste trabalho de pesquisa é desenvolver ciclos de condução para ônibus urbanos a partir de dados de campo, visando sua aplicação em metodologias de estimativa de emissões de poluentes. São apresentadas metodologias para a construção de ciclos de condução, com destaque para o procedimento que utiliza o conceito de VSP (Vehicle Specific Power), variável que apresenta forte correlação com emissões de poluentes. Assim, foram coletados dados da variação da velocidade ao longo do tempo em ônibus que realizam testes de durabilidade, percorrendo diariamente diferentes tipos de vias urbanas em um trajeto pré-determinado. Foram selecionados segmentos do trajeto que, agrupados, podem representar diferentes condições de operação para ônibus urbanos; em seguida, foram propostos ciclos de condução para estes segmentos escolhidos, nos períodos de "pico" e "fora do pico". Foram estimadas as emissões dos principais poluentes para os ciclos de condução desenvolvidos. Os resultados mostram que as características das vias e as condições de tráfego desfavoráveis podem impactar diretamente na distribuição de VSP e, consequentemente, ocasionar emissões mais elevadas de poluentes.

Palavras-chave: ciclos de condução, ônibus urbanos, estimativa de emissões, VSP. 


\begin{abstract}
The main objective of this research is to develop driving cycles for urban buses from experimental data, with the purpose of estimating pollutant emissions. The study presents different methodologies for the construction of driving cycles, with emphasis on a procedure that uses the VSP concept (Vehicle Specific Power), a variable with high correlation to pollutant emissions. Data from speed variation were collected from a bus performing urban endurance tests, driving through many types of urban roads on a predefined route. Segments from the entire route were selected to represent different operating conditions for buses, during peak and off-peak periods, for which several driving cycles were developed. Pollutant emissions were estimated for these cycles. The results show that road characteristics and adverse traffic conditions can impact directly on VSP distribution and therefore lead to higher pollutant emissions.
\end{abstract}

Keywords: driving cycles, urban bus operation, emissions estimation, VSP. 


\section{LISTA DE ILUSTRAÇÕES}

Figura 1 - Representação esquemática de uma instalação com dinamômetro de chassis para medição de emissões veiculares (Franco et al., 2013). 23

Figura 2 - Ciclo de condução Orange County, SAE J2711 (SAE, 2002). 24

Figura 3 - Ciclo de condução Manhattan, SAE J2711 (SAE, 2002). 25

Figura 4 - Ciclo de condução UDDS, SAE J2711 (SAE, 2002). 26

Figura 5 - Perfis dos ciclos de condução Manhattan, Orange County e Expresso Tiradentes (IPT, 2007). 27

Figura 6 - Modos de teste ESC: (a) tabela de dados e (b) gráfico de carga por rotação do motor (ambos em \%) (DIESELNET, 2012).

Figura 7 - ETC European transient cycle - Ciclo transiente europeu (DIESELNET, 2012). 30

Figura 8 - Consumo de combustível do motor em função da (a) aceleração e (b) VSP para ciclos FTP e HL07 (Jimenez-Palacios, 1999). 38

Figura 9 - Emissões de NOx na saída do motor em função da (a) aceleração e (b) VSP para ciclos FTP e HL07 (Jimenez-Palacios, 1999).

Figura 10 - Evolução das regulamentações de emissões para veículos pesados na Europa (Euro) e Estados Unidos (EPA) (Clark et al., 2007).

Figura 11 - Módulos Racelogic (a) VBOX e (b) CAN02 utilizados para aquisição e gravação de dados no experimento (Racelogic, 2012a).

Figura 12 - Esquema de funcionamento dos equipamentos em conjunto (Racelogic, 2012b). 
Figura 13 - Fluxograma do procedimento de aquisição de dados com os equipamentos VBOX e CAN02.

Figura 14 - Exemplo de planilha com dados adquiridos pelo GPS e salvos pelo data logger em $1 \mathrm{~Hz}$ - em destaque tempo, coordenadas geográficas, velocidade GPS e elevação.

Figura 15 - Ônibus urbano modelo Mercedes-Benz OF1721 Euro5 utilizado no experimento. (a) Visão geral e (b) interior do veículo com exemplo de carga utilizada.

Figura 16 - Instalação dos equipamentos de medição no ônibus de testes. No detalhe do canto direito superior, posicionamento da antena na fase 01. 51

Figura 17 - Distribuição de horas de testes por dia da semana na primeira fase do experimento. 53

Figura 18 - Distribuição dos testes por motorista na primeira fase do experimento. .54

Figura 19 - Desvio entre medidas de velocidade VCAN e VGPS. 56

Figura 20 - Distribuição de VSP para as fontes de velocidade VCAN e VGPS 56

Figura 21 - Distribuição de VSP para o total de dados adquiridos na fase 1. 59

Figura 22 - Fluxograma para seleção de microviagens segundo Lai et al (2012)....62

Figura 23 - Ciclo de condução do trajeto completo na fase 1 (Ciclo 01) considerando somente RMSE das microviagens.

Figura 24 - Histograma da distribuição de VSP para o ciclo 01 e a amostra total de dados. 64

Figura 25 - Comparação de tempo parado x duração das microviagens classificadas em ordem crescente de RMSE - fase 1. 
Figura 26 - Faixas de percentual de tempo parado por microviagem - Amostra de dados da fase 1

Figura 27 - Fluxograma para seleção de microviagens considerando duração máxima 240s e proporção de tempo parado pré-definindo.

Figura 28 - Ciclo 02 formado por microviagens selecionadas pelo VSP e percentual de tempo parado - ordenadas por RMSE crescente.

Figura 29 - Comparativo de dist. de VSP para ciclo 02 e amostra total (Total). 69

Figura 30 - Distribuição de velocidade (a) e aceleração (b) para os ciclos 01, 02 e amostra total.

Figura 31 - Trecho A - R. Antonio Doll de Morais / Av.Conceição / Av. Engenheiro Armando de Arruda Pereira (Diadema / São Paulo) - Percorrida no sentido A-B.....75

Figura 32 - Imagem do trecho A, na av. Eng. Armando de Arruda Pereira com corredor central de circulação exclusiva de ônibus (Google Street View). 76

Figura 33 - Distribuição de VSP para o tr. A nos horários de pico e fora de pico......77

Figura 34 - Ciclo de condução para o trecho A nos horários de pico. 78

Figura 35 - Ciclo de condução para o trecho A fora dos horários de pico. 79

Figura 36 - Trecho B - Av. Prestes Maia / Av. do Taboão - (São Bernardo do Campo/Diadema) - Percorrida em ambos os sentidos. 80

Figura 37 - Imagem da Avenida do Taboão, em São Bernardo do Campo, parte do trecho B. Separação por "tartarugas" impede ultrapassagens pela contramão (Google Street View).

Figura 38 - Distribuição de VSP para o trecho B nos horários de pico e fora de pico. 
Figura 39 - Ciclo de condução para o trecho B 83

Figura 40 - Trecho C - Av. do Cursino (São Paulo) - Percorrida somente no sentido A-B. 84

Figura 41 - Imagem da av. do Cursino, trecho C, em dois pontos distintos (Google Street View). 84

Figura 42 - Distribuição de VSP para o tr. C nos horários de pico e fora de pico. 85

Figura 43 - Ciclo de condução para o trecho C. 86

Figura 44 - Trecho D - Av. José Cabalero / R. Cel. Alfredo Flaquer / Av. Santos Dumont / R. Giovanni Battista Pirelli / Av. João Ramalho (Santo André) - Percorrida em ambas as direções A-B. 88

Figura 45 - Imagem do tr. D, Av. Giovanni Battista Pirelli (Google Street View). 89

Figura 46 - Distribuição de VSP para o tr. D nos horários de pico e fora de pico......90

Figura 47 - Ciclo de condução para o trecho D nos horários de pico. 91

Figura 48 - Ciclo de condução para o trecho $\mathrm{D}$ fora dos horários de pico. 92

Figura 49 - Trecho E - Av. Engenheiro Armando de Arruda Pereira / Av. Dr. Hugo Beolchi / Av. Jabaquara / R. Domingos de Morais (São Paulo) - Percorrida somente no sentido A-B. 93

Figura 50 - Imagem da Av. Jabaquara, que compõe o tr. E (Google Street View)....94

Figura 51 - Distribuição de VSP para o tr. E nos horários de pico e fora de pico......95

Figura 52 - Ciclo de condução para o trecho E nos horários de pico. 96

Figura 53 - Ciclo de condução para o trecho E fora dos horários de pico. 97 
Figura 54 - Amostras de fatores de emissões em g/h de NOx (a), HC (b), MP2.5 (c) e CO (d) para os modos de operação do MOVES (Estados Unidos, 2009). 104

Figura 55 - Estimativa de emissões para os ciclos de condução do trecho A, no pico e fora do pico. 107

Figura 56 - Estimativa de emissões para os ciclos de condução do trecho D, no pico e fora do pico. 108

Figura 57 - Estimativa de emissões para os ciclos de condução do trecho E, no pico e fora do pico. 108

Figura 58 - Estimativa de emissões para os ciclos de condução dos períodos de pico, trechos $E, A$ e $D$ 109

Figura 59 - Estimativa de emissões para os ciclos de condução dos períodos fora do pico, trechos $E, A$ e $D$ 110

Figura 60 - Estimativa de emissões para os ciclos de condução dos tr. B e C. ......110

Figura 61 - Comparativo de velocidade média e estimativa de emissões totais para os ciclos de condução desenvolvidos por trecho e período. 


\section{LISTA DE TABELAS}

Tabela 1 - Características de ciclos de condução SAE J2711 x Expresso Tiradentes (IPT, 2007)

Tabela 2 - Fatores de emissão de poluentes principais em motores diesel por fase do PROCONVE, em g/kWh, (Brasil, 2011).

Tabela 3 - Tempo médio de paradas - Comparativo do experimento e Lai et al. (2012).

Tabela 4 - Resumo de dados adquiridos durante a fase 2 do experimento 55

Tabela 5 - Distribuições de VSP para velocidades adquiridas pelas fontes CAN e GPS.

Tabela 6 - Valores utilizados no cálculo de VSP - baseados em Zhai et al. (2008)..59

Tabela 7 - Distribuição VSP para a amostra total de dados da fase 1. 60

Tabela 8 - Resumo das microviagens utilizadas na construção do ciclo 01 63

Tabela 9 - Distribuição de tempo parado das microviagens do ciclo 02. 68

Tabela 10 - Características das microviagens que compõe o ciclo 02. 69

Tabela 11 - Resumo comparativo entre as distribuições de VSP para os ciclos 01, 02 e o total de dados adquiridos. 70

Tabela 12 - Resultados comparativos ciclos 01, 02 e Total. 70

Tabela 13 - Informações básicas das vias selecionadas para análise individual. ....73

Tabela 14 - Distribuição das observações segundo os horários de pico e fora de pico nos trechos percorridos durante o experimento 
Tabela 15 - Indicadores básicos das microviagens do trecho A para horários de pico e fora de pico 76

Tabela 16 - Distribuição das faixas de VSP para o trecho A nos horários de pico e fora de pico.

Tabela 17 - Distribuição das faixas de VSP para os horários de pico no trecho A, na amostra total e no ciclo construído.

Tabela 18 - Distribuição das faixas de VSP para os horários fora de pico no trecho A, na amostra total e no ciclo construído.

Tabela 19 - Indicadores básicos das microviagens do trecho B para horários de pico e fora de pico

Tabela 20 - Distribuição das faixas de VSP para o trecho B, na amostra total e no ciclo construído.

Tabela 21 - Indicadores básicos das microviagens do trecho $\mathrm{C}$ para horários de pico e fora de pico

Tabela 22 - Distribuição das faixas de VSP para o trecho C nos horários de pico e fora de pico.

Tabela 23 - Distribuição das faixas de VSP para o trecho C, na amostra total e no ciclo construído.

Tabela 24 - Indicadores básicos das microviagens do trecho D para horários de pico e fora de pico.

Tabela 25 - Distribuição das faixas de VSP para os horários de pico no trecho D, na amostra total e no ciclo construído.

Tabela 26 - Distribuição das faixas de VSP para os horários fora de pico no trecho D, na amostra total e no ciclo construído. 
Tabela 27 - Indicadores básicos das microviagens do trecho E para horários de pico e fora de pico

Tabela 28 - Distribuição das faixas de VSP para o trecho E nos horários de pico e fora de pico.

Tabela 29 - Distribuição das faixas de VSP para os horários de pico no trecho E, na amostra total e no ciclo construído.

Tabela 30 - Distribuição das faixas de VSP para os horários fora de pico no trecho E, na amostra total e no ciclo construído. 97

Tabela 31 - Comparativo de resultados nos horários de pico para as amostras e ciclos. 99

Tabela 32 - Comparativo de resultados fora dos horários de pico para as amostras e ciclos. 100

Tabela 33 - Definição dos modos de operação do MOVES, adaptado de Estados Unidos (2009). 102

Tabela 34 - Modos de operação identificados para os ciclos de condução dos trechos A-E. 106 


\section{LISTA DE ABREVIATURAS E SIGLAS}

$\begin{array}{ll}\text { ABNT } & \text { Associação brasileira de normas técnicas } \\ \text { CO } & \text { Monóxido de carbono } \\ \text { ECU } & \text { Electronic Central Unit } \\ \text { GPS } & \text { Environmental Protection Agency } \\ \text { HC } & \text { Global Positioning System } \\ \text { HHD } & \text { Hidrocarboneto } \\ \text { MHD } & \text { Heavy Heavy-Duty } \\ \text { MOVES } & \text { Medium Heavy-Duty } \\ \text { MP } & \text { Motor Vehicle Emissions Simulator } \\ \text { NOx } & \text { Material particulado } \\ \text { PROCONVE } & \text { Óxidos de nitrogênio } \\ \text { PBT } & \text { Programa de controle da poluição do ar por veículos } \\ \text { RAE } & \text { Peso bruto total } \\ \text { RHCO } & \text { Society of Automotive Engineers } \\ \text { RMSE } & \text { Aldeídos } \\ \text { Root Mean Square Error } & \text { Vehicle Specific Power } \\ \text { SP } & \text { autores }\end{array}$




\section{SUMÁRIO}

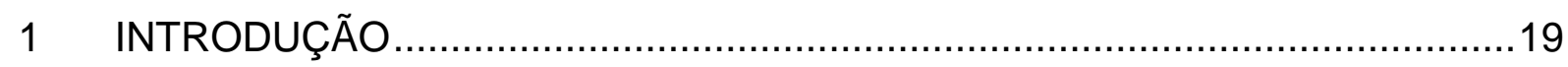

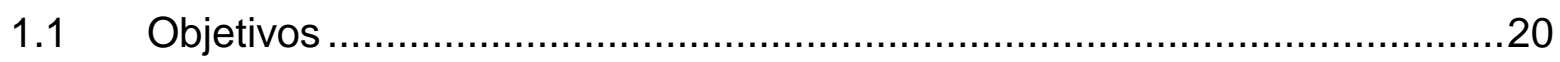

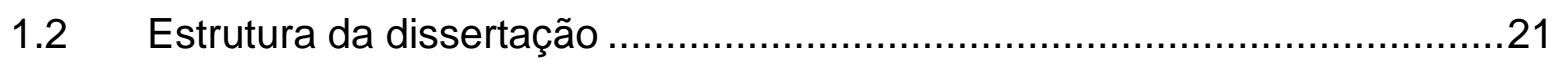

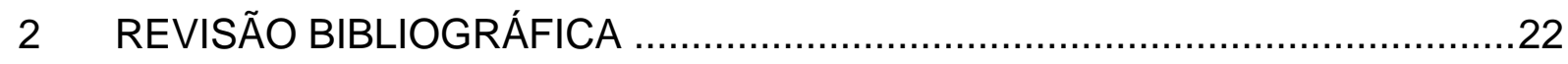

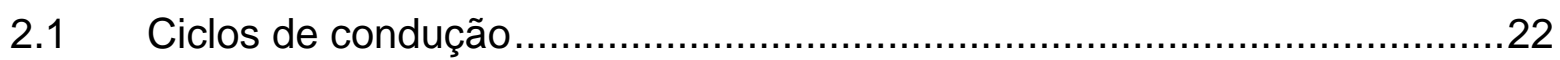

2.1.1 Ciclos SAE J2711, Ciclo IPT (Expresso Tiradentes) e ciclos de testes de motores . 24

2.2 Metodologias de construção de ciclos de condução ..................................31

2.2.1 Construção de ciclos baseada em microviagens (micro-trips) ……..........31

2.2.2 Construção de ciclos baseada em segmentos ......................................32

2.2.3 Construção de ciclos com classificação padronizada..............................33

2.2.4 Construção modal de ciclos ………...................................................33

2.2.5 Construção de ciclos baseada na distribuição VSP ................................34

2.3 VSP - Vehicle Specific Power ……………........................................

2.4 Emissões veiculares em motores diesel ..................................................

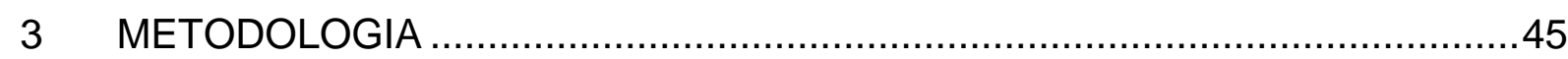

3.1 Aquisição de dados: Descrição do experimento …………………….......45

3.1.1 Experimento Fase 1 - Antena posicionada no painel do veículo .............52

3.1.2 Experimento Fase 2 - Antena posicionada no teto do veículo .................54

4 ANÁLISE DE DADOS E CONSTRUÇÃO DE CICLOS DE CONDUÇÃO .........58

4.1 Análise do trajeto completo e ciclo de condução 01 .................................58

4.2 Construção e análise do ciclo de condução 02 ….....................................65

4.3 Análise de VSP e construção de ciclos por trecho.....................................73

4.3.1 Trecho A - Rua Antonio Doll de Morais (Diadema), avenidas Conceição (São Paulo) e Eng. Armando de Arruda Pereira .................................................75 
4.3.2 Trecho B - Avenidas Prestes Maia (Diadema) e Taboão (São Bernardo

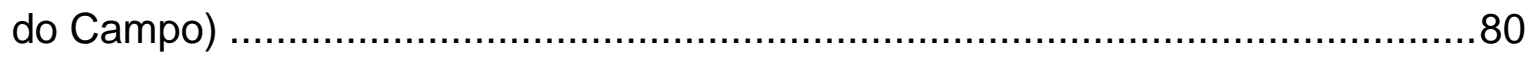

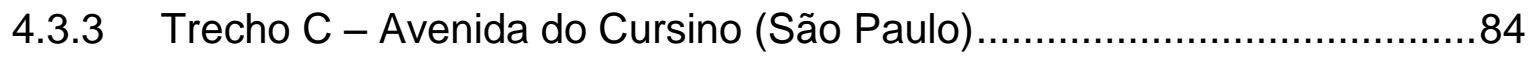

4.3.4 Trecho D - Av. José Cabalero, R. Cel. Alfredo Flaquer, Av. Santos Dumont, R. Giovanni Battista Pirelli e Av. João Ramalho (Santo André) 88

4.3.5 Trecho E - Avenidas Eng. Armando de Arruda Pereira, Dr. Hugo Beolchi, Jabaquara e Rua Domingos de Morais (São Paulo) 93

4.3.6 Síntese dos resultados - Construção dos ciclos de condução. 98

5 ESTIMATIVA DE EMISSÕES 101

5.1 Estimativa de emissões para os ciclos de condução desenvolvidos.........106

5.1.1 Comparação entre períodos de pico e fora de pico ..............................107

5.1.2 Comparação entre trechos ................................................................109

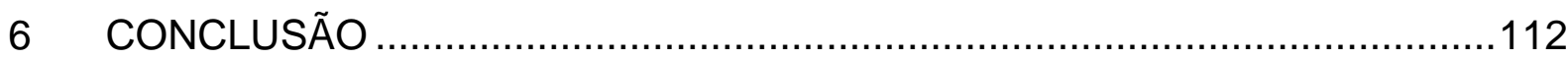

6.1 Recomendações de trabalhos futuros................................................114

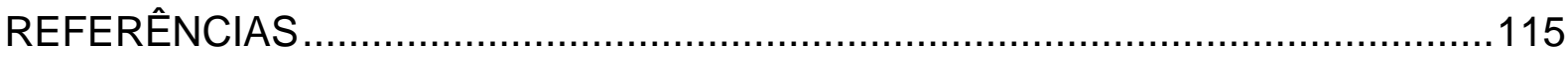




\section{INTRODUÇÃO}

Desenvolver ciclos de condução que representem de maneira adequada as condições reais de operação de ônibus urbanos é fundamental para que estimativas de emissões de poluentes próximas da realidade possam ser feitas.

Além disso, os ciclos de condução são essenciais para a certificação e homologação de veículos em emissões de poluentes e testes de consumo de combustível.

A estimativa de emissões, como problema de Engenharia de Transportes, é importante para avaliar os efeitos de diferentes condições de operação de ônibus sobre a poluição de uma região e auxiliar no desenvolvimento de estratégias de transporte público urbano.

Intervenções na infraestrutura de transporte, como a criação de faixas exclusivas e corredores de ônibus, priorização do tráfego dos ônibus em semáforos, alteração da distância entre paradas, entre outros, resultarão em alterações do perfil de condução dos veículos, o que, por fim, poderá ter impacto na emissão de poluentes.

Certamente, não apenas fatores oriundos da operação têm influência nas emissões, mas também aqueles diretamente ligados: (I) ao veículo, como tamanho, capacidade, motorização e tecnologia embarcada; (II) ao condutor, relativo à maneira de conduzir o veículo; (III) e também ao tipo e à qualidade do combustível utilizado.

Entretanto, o foco deste trabalho está nos fatores ligados à operação de transporte público, através do desenvolvimento de ciclos de condução para condições de operação específicas que deverão ser identificadas e apresentadas durante a análise da fase experimental. 


\subsection{OBJETIVOS}

O objetivo principal deste trabalho é construir ciclos de condução de ônibus urbanos com motores a diesel a partir de dados da operação simulada por veículo em teste, visando sua aplicação em metodologias de estimativa de emissões de poluentes.

Os objetivos secundários são:

- Comparar fontes de aquisição de dados de velocidade para construção de ciclos de condução - Velocidade adquirida pela central eletrônica do veículo (CAN) e pelo receptor GPS;

- Verificar o resultado do método de seleção de microviagens e construção de ciclos de condução com base no conceito de VSP (Vehicle Specif Powerpotência veicular específica);

- Comparar distribuições de VSP e ciclos de condução construídos para períodos de pico e fora de pico por trechos de vias com diferentes configurações;

- Estimar emissões para os ciclos de condução desenvolvidos e comparar o efeito de diferentes ciclos sobre a emissão de poluentes selecionados. 


\subsection{ESTRUTURA DA DISSERTAÇÃO}

$\mathrm{Na}$ revisão bibliográfica, no capítulo 2, são apresentados os conceitos mais relevantes para o desenvolvimento deste trabalho de pesquisa: ciclos de condução e metodologias para sua construção, apresentação do VSP (Vehicle Specific Power) e emissões veiculares.

O capítulo 3 apresenta a metodologia aplicada na aquisição dos dados do experimento com os equipamentos e demais recursos utilizados na sua execução. Além disso, são mostrados extratos dos dados adquiridos e a divisão do experimento em duas fases.

O quarto capítulo analisa os dados adquiridos pelo experimento e aplica um método de construção de ciclos de condução baseado na similaridade da distribuição de VSP, desenvolvendo dois ciclos iniciais a partir da amostra total de dados obtida. Em seguida, são apresentados os trechos selecionados do trajeto completo percorrido pelo veículo em teste, para a construção de ciclos de condução para os períodos de pico e fora do pico.

No capítulo 5 , são realizadas estimativas de emissões de poluentes para NOx (óxidos de nitrogênio), HC (hidrocarbonetos), MP (material particulado) e CO (monóxido de carbono), baseadas nas taxas de emissões coletadas pela EPA (Environmental Protection Agency - agência americana de proteção ambiental) para o desenvolvimento do software MOVES.

Por fim, as principais conclusões do trabalho e recomendações para desenvolvimentos futuros são apresentados no capítulo 6 . 


\section{REVISÃo BIBLIOGRÁFICA}

\subsection{CICLOS DE CONDUÇÃO}

Para Nesamani e Subramanian (2011) um ciclo de condução é uma sequência de condições de operação (marcha lenta, aceleração, desaceleração e cruzeiro), desenvolvida para representar um padrão típico de condução em uma região, sendo amplamente utilizado em estudos de emissões (Lai et al., 2012).

Além de servirem de apoio para estimativas e medições de emissões, ciclos de condução também podem ser utilizados para medir consumo de combustível, conforme a recomendação da norma SAE J2711 (2002).

Diversos ciclos de condução têm sido desenvolvidos por instituições de vários países. Esses ciclos, segundo Andrei (2001), variam consideravelmente entre si, uma vez que buscam reproduzir comportamentos de condução específicos, influenciados pelas condições de tráfego local e por características da rota percorrida.

Há ciclos de condução mais comumente utilizados, como, por exemplo os ciclos Manhattan e Orange County, que têm uso difundido nos Estados Unidos e Dutch Urban Bus e Braunschweig, mais comuns na Europa (Clark et al., 2007).

A duração dos ciclos de condução varia de um ou dois minutos até trinta minutos ou mais, apresentada normalmente de segundo a segundo, com duração limitada. Assim, visando reduzir custos de testes por veículo, esforços de desenvolvimento de ciclos de condução são desafiados a simular o comportamento real dos veículos (Dai et al., 2008).

Para ensaios tanto de motores quanto de veículos são utilizados dinamômetros, equipamentos que simulam a potência resistiva imposta às rodas de um veículo, capazes de aplicar velocidade e carga controlada para fins de medição de um motor ou veículo em termos de torque, potência, simulação de movimento, entre outros. 
Veículos de passeio e comerciais leves são comumente testados em dinamômetros de chassis (veículo completo), conforme Figura 1, enquanto veículos pesados têm somente seus motores testados em dinamômetros de motor, uma vez que esses motores são utilizados para diferentes aplicações (Majewski e Khair, 2006).

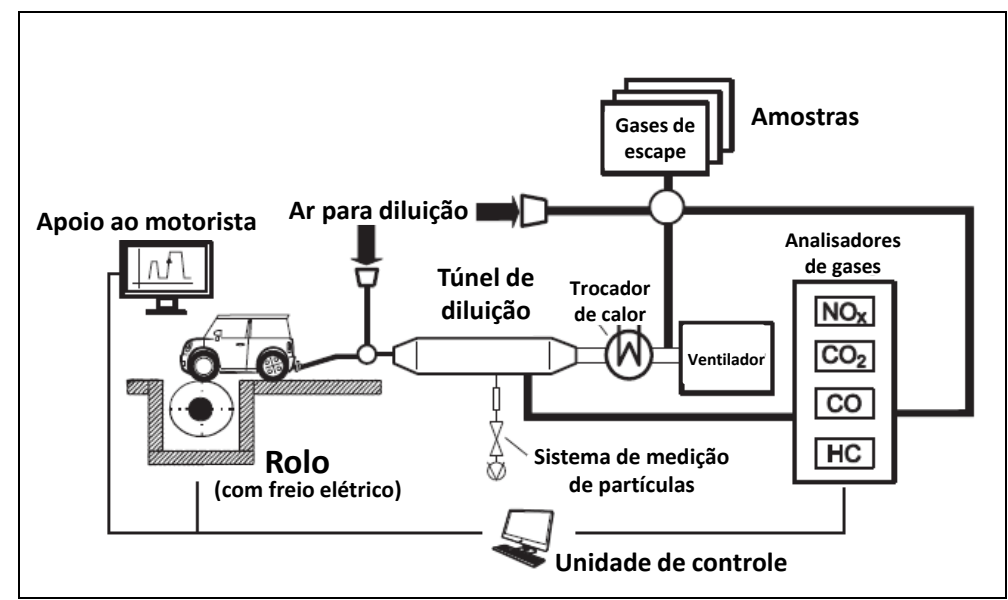

Figura 1 - Representação esquemática de uma instalação com dinamômetro de chassis para medição de emissões veiculares (Franco et al., 2013).

Os métodos padronizados de certificação de veículos pesados para emissões são baseados somente em testes de motores (Clark et al., 2007). Entretanto, este método tem diversas limitações. Primeiramente, testes de motores não contam com as características do veículo (peso, trem de força, estrutura da carroceria, layout do sistema de arrefecimento, etc.). Além disso, um teste de motor não é o ideal para a avaliação da utilização de um veículo.

Outro aspecto a ser considerado é que a remoção de um motor de um veículo é bastante trabalhosa e os modelos mais modernos estão atrelados a sistemas eletrônicos cada vez mais complexos oriundos do veículo completo e não somente do trem de força.

Ao se testar veículos completos em dinamômetros resolvem-se muitos dos problemas e ultrapassam-se as limitações citadas anteriormente. Adicionalmente, as medidas de emissões baseadas em veículos completos resultam em uma unidade específica de gramas por quilômetros $(\mathrm{g} / \mathrm{km})$ em vez de por quilowatt-hora $(\mathrm{g} / \mathrm{kWh})$, esta última mais difícil de relacionar com condições reais de operação (Clark et al., 2007). 
Apesar de não haver uma metodologia universal para ensaios em dinamômetros de chassis para veículos pesados, diversos laboratórios ao redor do mundo estão obtendo resultados de emissões para veículos pesados completos. Em geral, estes ensaios estão focados em novos tipos de veículos, como, por exemplo, veículos que utilizam novas tecnologias de redução de emissões de gases de escape, trens de força mais modernos e/ou o uso de combustíveis alternativos (Clark et al., 2007).

Além disso, a Society of Automotive Engineers (SAE) publicou o documento SAE J2711 (Recommended Practice for Measuring Fuel Economy and Emissions of Hybrid-Electric and Conventional Heavy-Duty Vehicles, 2002), que lista as recomendações para medição de consumo de combustível e emissões em veículos comerciais pesados e propõe ciclos para estes fins.

\subsubsection{Ciclos SAE J2711, Ciclo IPT (Expresso Tiradentes) e ciclos de testes de motores}

O Orange County Transit Cycle, mostrado na Figura 2, é utilizado para representar a operação de ônibus em velocidades intermediárias (ex.: faixa de circulação exclusiva de ônibus). O ciclo Orange County é derivado dos dados coletados na operação real de ônibus urbanos em Orange County, Califórnia, e reflete uma grande variedade de acelerações, desacelerações e operações de cruzeiro. O ciclo Orange County tem uma velocidade média de $19,8 \mathrm{~km} / \mathrm{h}$ e duração de $1908 \mathrm{~s}$, percorrendo uma distância de 10,5 km (SAE, 2002).

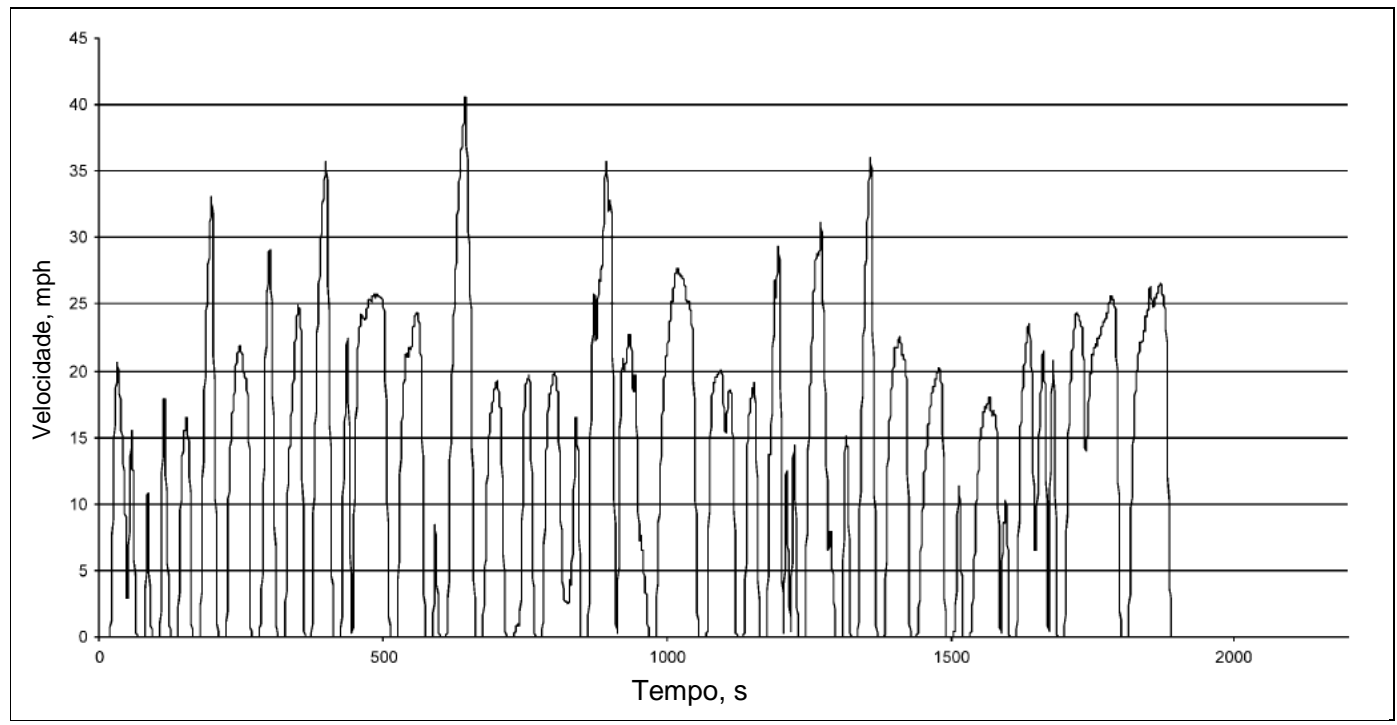

Figura 2 - Ciclo de condução Orange County, SAE J2711 (SAE, 2002). 
O Manhattan Cycle representa a operação de ônibus urbanos em baixas velocidades (trânsito compartilhado). Foi desenvolvido pela West Virginia University com dados obtidos na operação de ônibus na cidade de Nova lorque. Este ciclo possui uma duração inferior ao Orange County, com $1089 \mathrm{~s}$, velocidade média de $11 \mathrm{~km} / \mathrm{h}$ em um percurso de 3,32 km. Na Figura 3, o ciclo Manhattan (SAE, 2002).

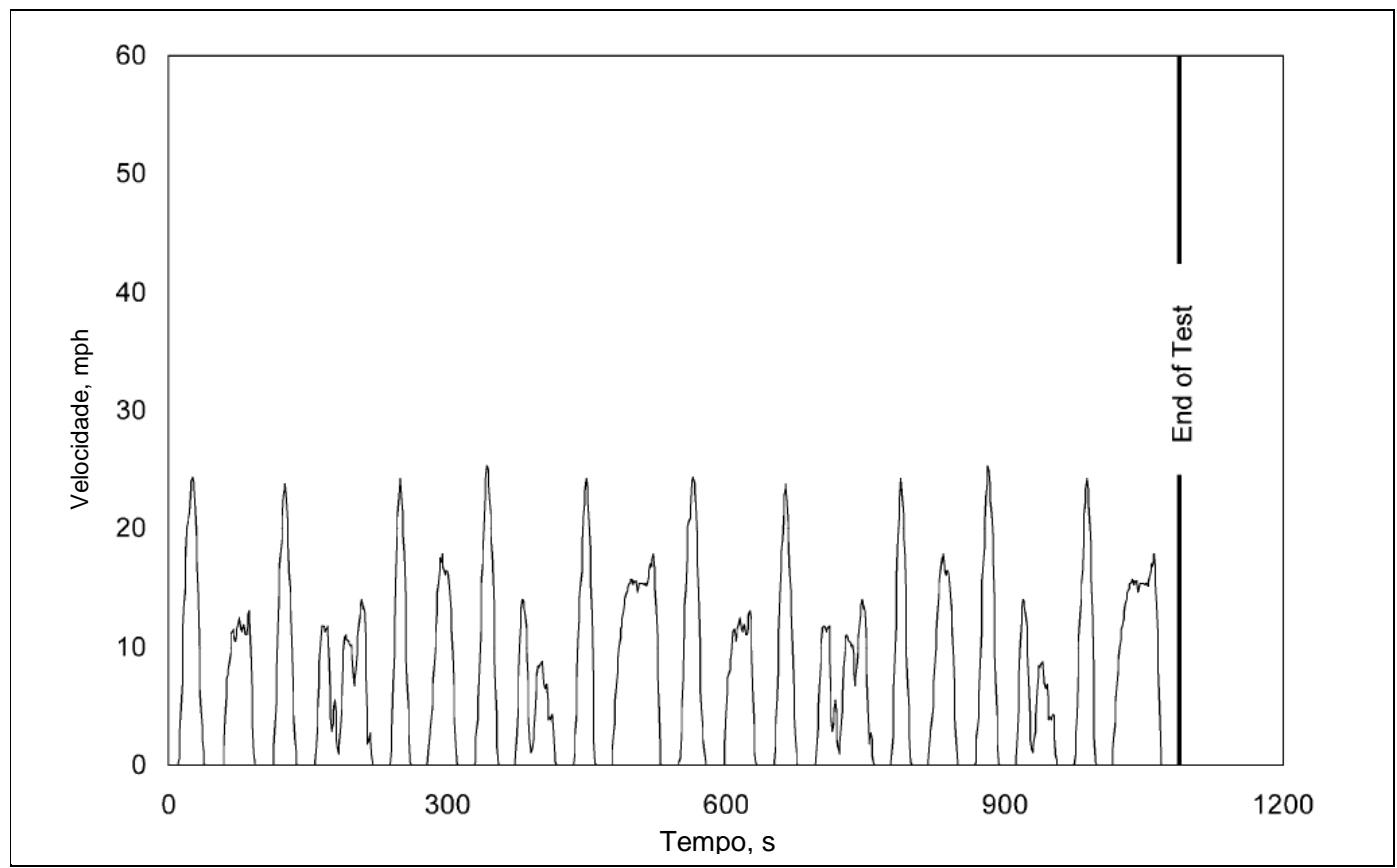

Figura 3 - Ciclo de condução Manhattan, SAE J2711 (SAE, 2002).

Um terceiro ciclo apresentado é o UDDS (Urban Dynamometer Driving Schedule programa de condução urbana em dinamômetro), na Figura 4, que representa o tráfego em altas velocidades para ônibus e também caminhões. Sua velocidade média é de aproximadamente $30,1 \mathrm{~km} / \mathrm{h}$ em $1061 \mathrm{~s}$ em cerca de 8,9 km (SAE, 2002). 


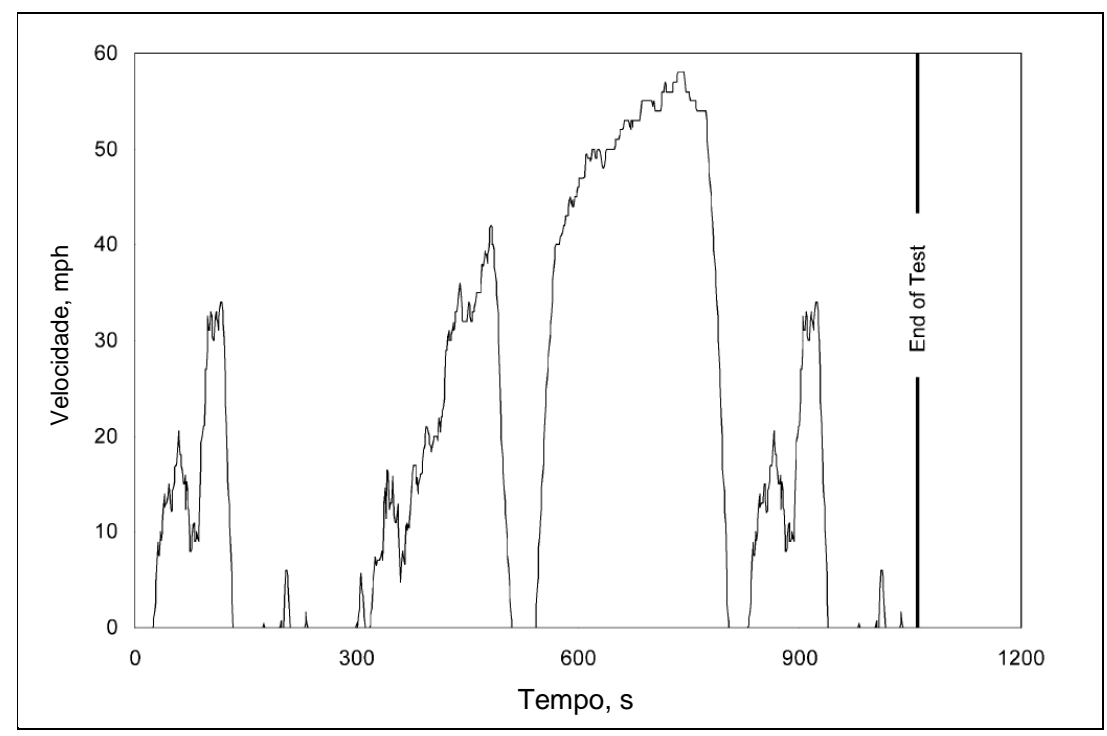

Figura 4 - Ciclo de condução UDDS, SAE J2711 (SAE, 2002).

Adicionalmente aos ciclos citados acima, no trabalho realizado pelo Instituto de Pesquisas Tecnológicas (IPT, 2007) é apresentado o ciclo do Expresso Tiradentes (corredor de circulação exclusiva de ônibus urbanos da cidade de São Paulo - BRT - Bus Rapid Transit), que representa o perfil de velocidade em função do tempo para um ônibus simulando a condição de operação planejada para este corredor, que à época da publicação do trabalho estava sendo concluído. Como esperado, este ciclo possui velocidade média superior aos ciclos Manhattan e Orange County, já que se trata de um corredor completamente separado do tráfego geral, sem semáforos ou outras paradas além das estações. A média de velocidade para este ciclo foi de $26,2 \mathrm{~km} / \mathrm{h}$ em $1080 \mathrm{~s}$ com um percurso total de $7,86 \mathrm{~km}$.

A Figura 5 apresenta um gráfico com as curvas sobrepostas dos ciclos de condução Manhattan, Orange County e Expresso Tiradentes, onde é possível verificar principalmente as diferenças na duração dos ciclos e nos padrões de variação de velocidade. 


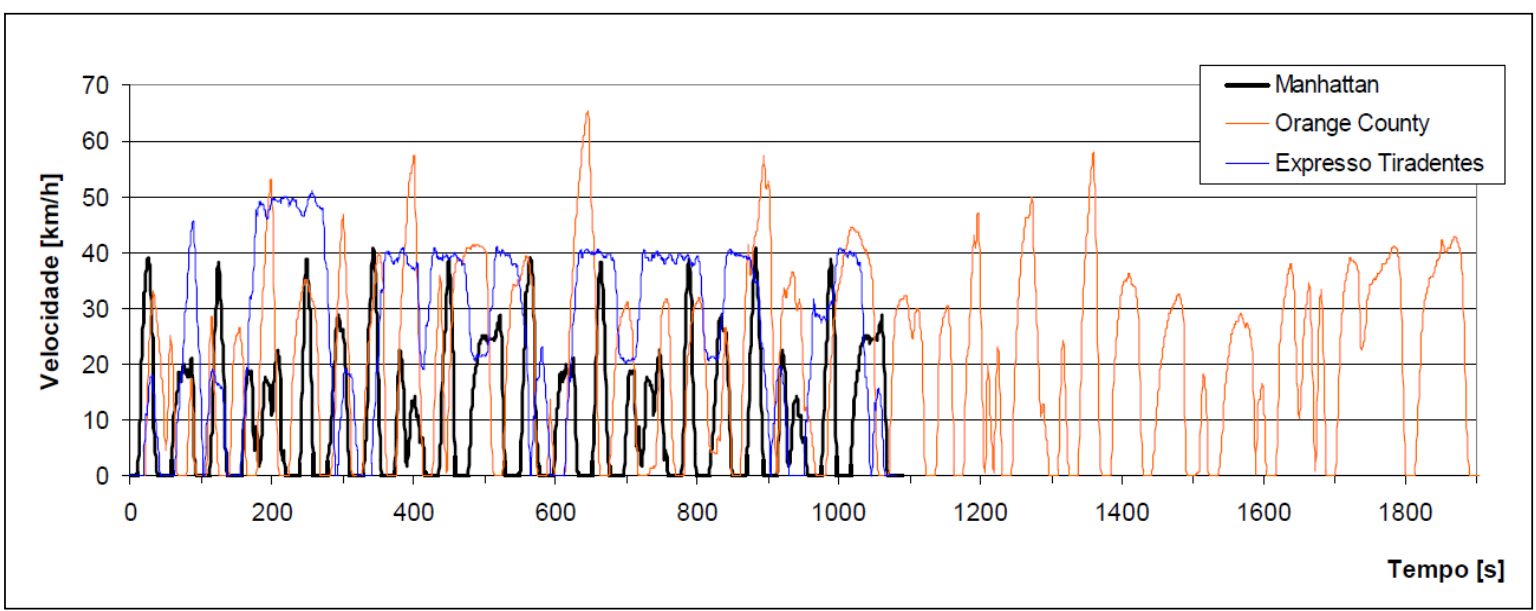

Figura 5 - Perfis dos ciclos de condução Manhattan, Orange County e Expresso Tiradentes (IPT, 2007).

A Tabela 1 mostra uma visão geral dos principais parâmetros que caracterizam os ciclos descritos anteriormente, Manhattan, Orange County e Expresso Tiradentes.

Tabela 1 - Características de ciclos de condução SAE J2711 x Expresso Tiradentes (IPT, 2007).

\begin{tabular}{lcrrr}
\hline \multirow{2}{*}{ Grandeza } & \multirow{2}{*}{ Unidade } & \multicolumn{2}{c}{$\mathrm{SAE}$ J2711 } & \multicolumn{2}{c}{ Expresso } \\
\hline $\mathrm{V}_{\text {média }}$ & $\mathrm{km} / \mathrm{h}$ & 11,00 & 19,8 & 26,2 \\
$\sigma_{\mathrm{v}}$ & $\mathrm{km} / \mathrm{h}$ & 11,80 & 16,6 & 15,8 \\
$\sigma_{\mathrm{v}} \mathrm{N}_{\text {média }}$ & $\%$ & $107 \%$ & $84 \%$ & $60 \%$ \\
$\mathrm{~V}_{\text {máx }}$ & $\mathrm{km} / \mathrm{h}$ & 40,7 & 65,4 & 51,0 \\
$\mathrm{~A}_{\text {máx }}$ & $\mathrm{m} / \mathrm{s}^{2}$ & 1,8 & 1,8 & 1,5 \\
$-\mathrm{A}_{\text {max }}$ & $\mathrm{m} / \mathrm{s}^{2}$ & $-2,6$ & $-2,3$ & $-2,0$ \\
$\mathrm{~T}_{\text {total }}$ & $\mathrm{S}$ & 1089 & 1908 & 1080 \\
$\mathrm{~T}_{\text {parado }}$ & $\mathrm{S}$ & 393 & 406 & 151 \\
$\mathrm{~T}_{\text {parado }} / \mathrm{T}_{\text {total }}$ & $\%$ & $36 \%$ & $21 \%$ & $14 \%$ \\
$\mathrm{D}_{\text {total }}$ & $\mathrm{km}$ & 3,32 & 10,5 & 7,86 \\
$\mathrm{~N}^{\circ}$ paradas no & ciclo & 20 & 30 & $11^{*}$ \\
$\mathrm{~N}^{\circ}$ paradas $/ \mathrm{km}$ & 6,2 & 2,9 & $1,4^{*}$ \\
\hline
\end{tabular}

* Na verdade, o expresso Tiradentes operava na época com somente seis paradas, o que implica em 0,8 parada $/ \mathrm{km}$. As paradas adicionais devem-se ao critério de simular uma parada adicional antes de cada ponto, supondo que os ônibus precisem aguardar seu antecessor liberar as plataformas

Nesta tabela são apresentadas as seguintes grandezas: velocidade média $\left(\mathrm{V}_{\text {média }}\right)$, desvio padrão de velocidade $(\sigma \mathrm{V})$, relação desvio padrão - velocidade média ( $\left.\sigma \mathrm{v} / \mathrm{V}_{\text {média }}\right)$, velocidade máxima $\left(\mathrm{V}_{\text {máx }}\right)$, aceleração máxima $\left(A_{\max }\right)$, desaceleração máxima $\left(-A_{\max }\right)$, tempo total de percurso $\left(T_{\text {total }}\right)$, tempo total com o veículo parado ( $\left.T_{\text {parado }}\right)$, distância total percorrida $\left(D_{\text {total }}\right)$ e número de paradas. Para fazer a comparação das grandezas associadas à extensão do trajeto, foram definidas duas novas grandezas: fração de tempo parado e número de paradas por quilômetro. 
Além dos ciclos de condução veicular, existem também os ciclos de testes de motores, utilizados convencionalmente para testes e homologação de emissões em motores pesados.

Ciclos de testes de emissões em motores são sequências de velocidade e de condições de carregamento executadas em um dinamômetro e podem ser divididos em estacionário ou transiente (Majewski e Khair, 2006).

Os ciclos estacionários, a exemplo dos ciclos de motores para dinamômetros ESC (European Steady Cycle - Ciclo estacionário europeu), consistem em uma sequência de modos definidos por diferentes condições de carregamento e velocidade do motor. Em conjunto com o ETC (European Transient Cycle - Ciclo transiente europeu) o ESC foi introduzido em 2000 na Europa para a certificação de motores pesados em emissões.

No ciclo ESC, o motor é testado em um dinamômetro de acordo com uma sequência de 13 modos estacionários, conforme Figura 6. O motor deve ser operado durante 0 tempo previsto em cada modo, completando as mudanças de velocidade e carga para o modo seguinte nos primeiros 20 segundos. A velocidade e torque especificados do motor devem ser garantidos com uma margem de $\pm 50 \mathrm{rpm}$ e $2 \%$ respectivamente (Majewski e Khair, 2006).

As emissões são medidas para cada uma dessas condições, sendo que o resultado final é calculado como a média ponderada de todos os modos de teste. As emissões de material particulado são coletadas em um filtro durante os 13 modos de execução. Os resultados finais do teste de emissões são expressos em g/kWh.

Durante os testes de certificação de emissões, os profissionais envolvidos podem solicitar modos adicionais aleatórios dentro da área de controle do ciclo (expressa em verde na Figura 6). As emissões máximas nestes modos extras são determinadas através da interpolação dos limites para os modos de teste regulares (Majewski e Khair, 2006). 


\begin{tabular}{|c|c|r|r|r|}
\hline \multirow{2}{*}{ Modo } & Velocidade & Carga & Ponderação & \multicolumn{1}{c|}{ Duração } \\
\cline { 3 - 5 } & do motor & \multicolumn{1}{c|}{ (\%) } & (\%) & (minutos) \\
\hline 1 & Marcha lenta & 0 & 15 & 4 \\
\hline 2 & $\mathrm{~A}$ & 100 & 8 & 2 \\
\hline 3 & $\mathrm{~B}$ & 50 & 10 & 2 \\
\hline 4 & $\mathrm{~B}$ & 75 & 10 & 2 \\
\hline 5 & $\mathrm{~A}$ & 50 & 5 & 2 \\
\hline 6 & $\mathrm{~A}$ & 75 & 5 & 2 \\
\hline 7 & $\mathrm{~A}$ & 25 & 5 & 2 \\
\hline 8 & $\mathrm{~B}$ & 100 & 9 & 2 \\
\hline 9 & $\mathrm{~B}$ & 25 & 10 & 2 \\
\hline 10 & $\mathrm{C}$ & 100 & 8 & 2 \\
\hline 11 & $\mathrm{C}$ & 25 & 5 & 2 \\
\hline 12 & $\mathrm{C}$ & 75 & 5 & 2 \\
\hline 13 & $\mathrm{C}$ & 50 & 5 & 2 \\
\hline
\end{tabular}

(a)

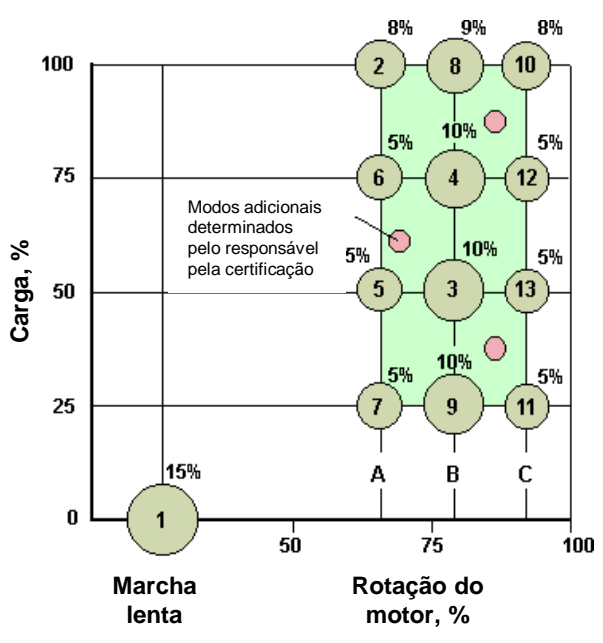

(b)

Figura 6 - Modos de teste ESC: (a) tabela de dados e (b) gráfico de carga por rotação do motor (ambos em \%) (DIESELNET, 2012).

O ciclo transiente ETC, mostrado na Figura 7, considera, além das informações dos ciclos estacionários, mudanças no modo de operação ao capturar diferentes padrões de condução, tais como o urbano, o rural e o rodoviário (Nesamani e Subramanian, 2011).

Majewski e Khair (2006) descrevem detalhadamente cada trecho do ciclo ETC. A primeira parte representa a condução urbana com velocidade máxima de $50 \mathrm{~km} / \mathrm{h}$ com partidas e paradas frequentes e tempo maior de paradas. A segunda parte representa o trecho rural, contendo um segmento íngreme, com velocidade média de $72 \mathrm{~km} / \mathrm{h}$. A última parte é o trecho rodoviário com velocidade média de aproximadamente $88 \mathrm{~km} / \mathrm{h}$.

Este ciclo foi desenvolvido em duas variantes, uma para dinamômetros de chassis e outra para teste e homologação de motores (Majewski e Khair, 2006). 


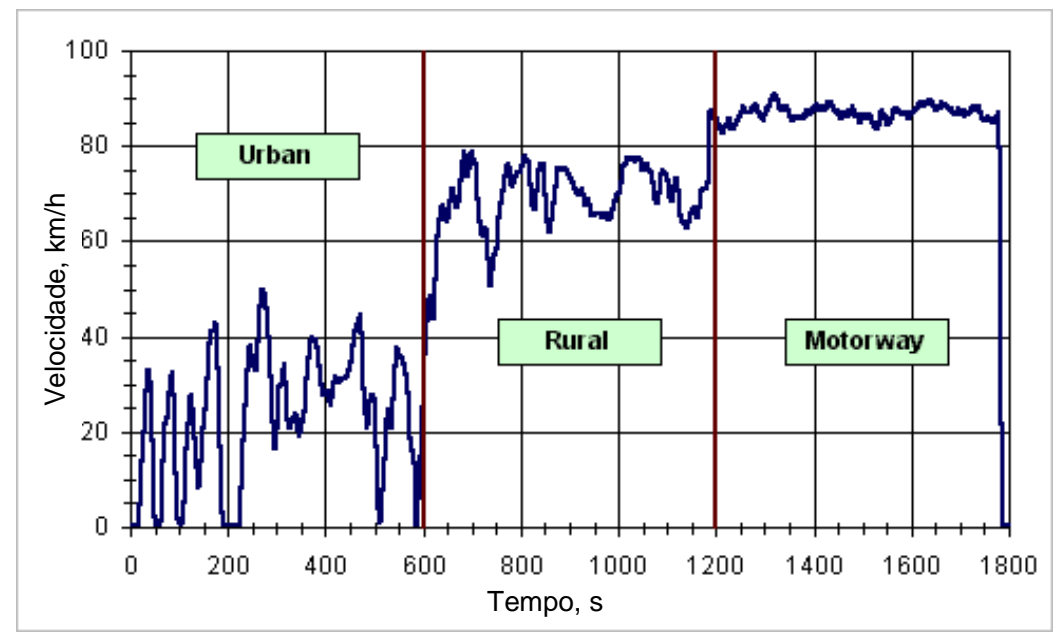

Figura 7 - ETC European transient cycle - Ciclo transiente europeu (DIESELNET, 2012).

Teoricamente, ciclos de testes de emissões em motores refletem alguns padrões de condução reais e os níveis de emissões associados, porém não é possível representar todas as condições de condução reais em um limitado conjunto de ciclos de teste (Majewski e Khair, 2006).

Para Clark et al. (2007), testar veículos utilizando ciclos de condução representativos tem importância crescente. Motores que funcionam bem em ciclos padronizados não têm necessariamente bom desempenho quando estão operando em situações reais. Isto é especialmente verdadeiro para as operações de ônibus que trabalham em baixas velocidades e cargas médias.

Além das velocidades máxima e média, aceleração e proporção de tempo parado, uma série de outros fatores são essenciais para o desenvolvimento de ciclos de condução tais como: a correlação entre velocidade e aceleração e as distribuições de velocidade e aceleração.

Desenvolver ciclos de condução específicos para as condições de tráfego locais é um requisito indispensável para possibilitar melhores estimativas de emissões e consumo de combustível (Nesamani e Subramanian, 2011). 


\subsection{METODOLOGIAS DE CONSTRUÇÃO DE CICLOS DE CONDUÇÃO}

André (2004) expõe que, de uma forma geral, métodos de construção de ciclos de condução incluem tipicamente as seguintes etapas:

1 Coleta de dados reais de condução;

2 Segmentação dos dados de condução;

3 Construção dos ciclos;

4 Avaliação e seleção do ciclo final.

Uma revisão das principais metodologias de construção de ciclos de condução é apresentada por Dai et al. (2008), citando quatro metodologias distintas, sendo elas a construção de ciclos por microviagens, por segmentos de viagens, baseada em classificação de padrões e a construção modal de ciclos. Além destas, será apresentada a metodologia proposta por Lai et al. (2012) de utilização do VSP (Vehicle Specific Power - Potência veicular específica) na construção de ciclos de condução.

\subsubsection{Construção de ciclos baseada em microviagens (micro-trips)}

Para Austin et al. (1993), microviagens são definidas como toda a atividade de condução entre paradas sequenciais, incluindo o tempo de parada inicial ou final (espera) do veículo. Através da combinação entre diversas microviagens é possível construir ciclos de condução. Dados da condução são coletados e em seguida são divididos em microviagens que deverão ser selecionadas para formar o ciclo de condução com o objetivo de se aproximar da condução observada na prática.

Microviagens são normalmente selecionadas utilizando-se um de três métodos: (I) seleção aleatória, (II) método da melhoria incremental (Best incremental), que faz buscas adicionais e acresce ao ciclo as microviagens com características específicas, (III) e a terceira, uma combinação de ambas as metodologias (Austin et al., 1993). Ciclos candidatos são avaliados utilizando parâmetros que tipicamente 
incluem velocidades médias, máximas e mínimas, aceleração e desaceleração média e a distribuição de frequência de velocidade e aceleração (SAFD - SpeedAcceleration Frequency Distribution).

A maior limitação dos métodos baseados em microviagens é que estas não diferenciam os diversos tipos de condições de condução como o tipo de via ou seu nível de serviço (Dai et al., 2008). Por exemplo, em uma condição de tráfego livre, um veículo para poucas vezes e uma única microviagem poderá representar diferentes tipos de via. Como resultado, reproduzir atividades de condução sob condições de tráfego específicas é difícil (André, 2004).

\subsubsection{Construção de ciclos baseada em segmentos}

O segmento de uma viagem é obtido dividindo os perfis de velocidade no tempo, utilizando alterações no tipo da via ou nível de serviço, além das paradas (Carlson e Austin, 1997). Desta forma, toda a condução do veículo poderá ser estratificada por tipo de via ou nível de serviço e, assim, os ciclos podem ser construídos para representar as condições de condução para tipos específicos de vias e condições de tráfego.

Da mesma maneira que o método baseado em microviagens, para a construção dos ciclos os segmentos de viagens são selecionados de forma aleatória, através do método da melhoria incremental ou pela combinação de ambos (Dai et al., 2008). Entretanto, diferentemente das microviagens, os segmentos de viagens podem se iniciar e terminar em qualquer velocidade. Desta forma, a combinação dos segmentos requer restrições de velocidade e aceleração entre os pontos que conectam os segmentos anteriores e posteriores.

Para Dai et al. (2008), a construção de ciclos baseada em segmentos de viagens é limitada por ser desenvolvida estritamente sob a perspectiva da engenharia de transportes e, consequentemente, menos relacionada a emissões. 


\subsubsection{Construção de ciclos com classificação padronizada}

Nesta proposta, sequências cinemáticas (similares às microviagens) são classificadas usando métodos estatísticos. Os ciclos de condução são construídos reconectando sequências cinemáticas selecionadas aleatoriamente. Este método vem sendo amplamente aplicado na construção dos ciclos de condução europeus (André et al., 1995).

De acordo com André et al. (1995), na construção dos ciclos urbanos europeus as sequências cinemáticas são descritas por vinte variáveis, entre elas: duração, tempo de parada, distância percorrida e outras como a velocidade instantânea e aceleração. Para estas vinte variáveis que compõem as sequências cinemáticas foi aplicada a análise de componentes principais (PCA - Principal Component Analysis), seguida por análise de agrupamentos (Cluster Analysis). Quatro agrupamentos distintos foram identificados representando tráfegos urbanos livres e congestionados, tráfego não urbano e em rodovia.

Em seguida, cada viagem foi visualizada como a combinação das diversas sequências cinemáticas. Essa observação permitiu que fossem identificados três tipos de viagens: urbanas, rodoviárias e de autoestradas.

Para Dai et al. (2008), apesar de diferenciar as condições cinemáticas da condução, este método não necessariamente diferencia as emissões associadas a essas atividades.

\subsubsection{Construção modal de ciclos}

Lin e Niemeier (2002) apresentam um método de construção de ciclo de condução baseado em modos, onde a condução é vista como uma sequência de modos como aceleração, desaceleração, cruzeiro ou espera (parada). Estudos mostram que emissões de fontes móveis são relacionadas com a operação modal dos veículos, além da velocidade média. Admitindo que a probabilidade de um evento modal específico ocorrer depende somente do modo do evento anterior, as atividades de condução podem ser modeladas como uma cadeia de Markov (Barth et al., 1996). 
Para Lin e Niemeier (2002), a construção modal de ciclos é composta de quatro etapas. Na primeira, os dados da condução são divididos em trechos menores de diferentes durações a partir da aceleração. Em seguida, os trechos são agrupados em "caixas" de acordo com o modo.

O terceiro passo cria uma matriz de transição que contém as probabilidades de sucessões entre os diferentes modos. Em seguida o ciclo é construído como uma cadeia de Markov; para cada trecho adicionado, a próxima "caixa" modal é prevista de acordo com o modo do trecho atual e com a matriz de transição. A seleção de cada trecho em uma dada "caixa" também é feita com o método da melhoria incremental para a SAFD (Distribuição de frequência de velocidade e aceleração) e é necessário que a velocidade do início do trecho seja adequada à velocidade final do trecho anterior com uma diferença determinada $(0,2 \mathrm{~km} / \mathrm{h}$ no trabalho de Lin e Niemeier, 2002). A seleção dos trechos é repetida até que a distância desejada para o ciclo seja alcançada.

\subsubsection{Construção de ciclos baseada na distribuição VSP}

Esta metodologia, proposta por Lai et al. (2012), considera que a potência veicular específica (VSP - vehicle specific power) é um parâmetro apropriado para auxiliar na construção de ciclos de condução, pois demonstra a relação próxima entre emissões e o padrão de condução.

O VSP, proposto por Jimenez-Palacios (1999), é definido como o consumo de energia de um veículo por tonelada transportada, incluindo a massa própria do veículo. O VSP pode ser calculado a partir da velocidade e aceleração medidas segundo a segundo, das características da via e do veículo, sendo expresso em $\mathrm{kW} / \mathrm{t}$ (quilowatt por tonelada). O conceito de VSP e sua relação com emissões serão apresentados no item 2.3.

No processo de estimativa de emissões o VSP é usualmente dividido em "caixas" (VSP bins), a cada uma das quais se associa uma taxa de emissão correspondente. A distribuição de VSP representa a proporção de tempo em cada "caixa" no tempo total de operação. 
No estudo de Lai et al. (2012), a metodologia proposta para a construção de ciclos de condução inclui três etapas principais: identificar as microviagens válidas, selecionar as microviagens e construir os ciclos de condução. É basicamente uma adaptação da metodologia de microviagens, considerando o parâmetro VSP na seleção das microviagens válidas.

Em seguida é feita uma comparação entre as distribuições VSP de cada microviagem e o conjunto das microviagens que pertencem a um dado grupo de velocidade. Para avaliar a similaridade das microviagens foi utilizado o critério do erro quadrático médio (RMSE - Root Mean Square Error). Menores valores de RMSE mostram maior similaridade entre uma microviagem e a amostra total de dados, e sua formulação é mostrada na equação 1, abaixo:

$$
R M S E=\sqrt{\frac{\sum_{i=-30}^{i=30}\left(\operatorname{Bin}_{m v, i}-\operatorname{Bin}_{t o t a l, i}\right)^{2}}{N-1}}
$$

onde $i$ é o identificador da "caixa" (Bin) de VSP entre -30 e 30kW/t, Bin $m v, i$ é a

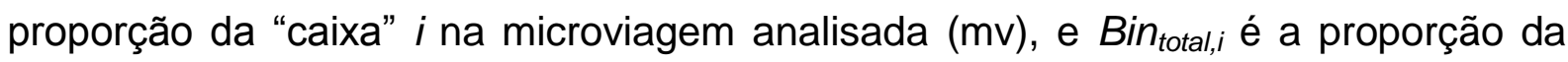
"caixa" i em todo o conjunto de dados (total), N é o número total de "caixas" de VSP, sendo normalmente de 21 (variação de -20 a $20 \mathrm{~kW} / \mathrm{t}$, somente valores inteiros). Entretanto neste trabalho também será utilizada a faixa de VSP entre -30 e $30 \mathrm{~kW} / \mathrm{t}$, pois pode representar maior proporção da amostra total de dados.

Lai et al. (2012) propõem a construção dos ciclos de condução em duas etapas: primeiro ordenam-se as microviagens segundo valores crescentes de RMSE e, em seguida, adicionam-se sequencialmente as microviagens a partir daquelas de menor valor de RMSE até que a duração pré-determinada para o ciclo seja atingida, aproximadamente 20 minutos no trabalho em questão.

Por fim, Lai et al. (2012) realizam uma análise comparativa das estimativas de emissões para os ciclos de condução propostos e ciclos de condução contidos no MOVES (Motor Vehicle Emission Simulator - Simulador de emissões de veículos a motor), sistema de modelagem de emissões de fontes móveis da agência de proteção ambiental dos Estados Unidos, EPA (Environmental Protection Agency). 
Na média, as emissões resultantes dos ciclos de condução desenvolvidos no estudo de Lai et al. (2012) foram 5\% inferiores àquelas baseadas nos ciclos padrão utilizados pelo MOVES. A comparação foi realizada para indicar os erros potenciais de se aplicar ciclos do MOVES diretamente, sem que exista uma calibração baseada nas informações locais de condução. 


\subsection{VSP - VEHICLE SPECIFIC POWER}

O conceito de potência veicular específica (VSP - Vehicle Specific Power) apresentado por Jimenez-Palacios (1999) é definido como a taxa instantânea de potência para a massa do veículo. Este parâmetro é muito útil para análise de informações de dinamômetro de chassis e modelagem de emissões.

Para Jimenez-Palacios (1999), o VSP pode ser calculado com uma aproximação adequada a partir de medidas da velocidade, aceleração do veículo e inclinação da via, além de estimativas de resistência aerodinâmica e à rolagem do veículo.

A correlação das emissões de CO (monóxido de carbono), HC (hidrocarbonetos) e NOx (óxidos de nitrogênio) com o VSP é maior do que com outros vários parâmetros comumente utilizados como velocidade, aceleração, potência absoluta ou consumo de combustível. Ou seja, uma vez conhecido o VSP, os valores de velocidade e aceleração não fornecem informações adicionais relativas às emissões (JimenezPalacios, 1999).

O VSP é um parâmetro mais adequado do que velocidade ou aceleração por ser mais diretamente relacionado à carga no motor do veículo e, consequentemente, às emissões. Este fato pode ser ilustrado pelas Figuras 8 e 9 , que mostram a variação de consumo de combustível (diretamente relacionado com emissões) e as emissões de NOx na saída do motor em função da aceleração e da potência específica para um dado veículo comercial leve. A correlação é maior com o VSP, mostrando uma clara tendência e menor dispersão nas medições experimentais realizadas por Jimenez-Palacios (1999). 


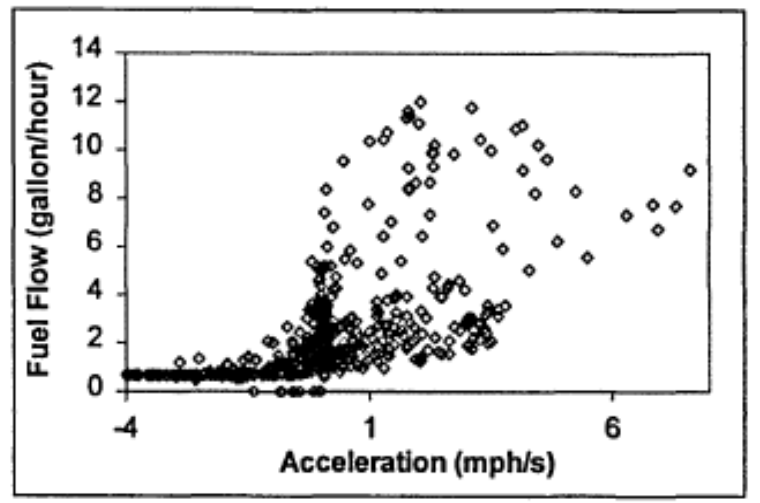

(a)

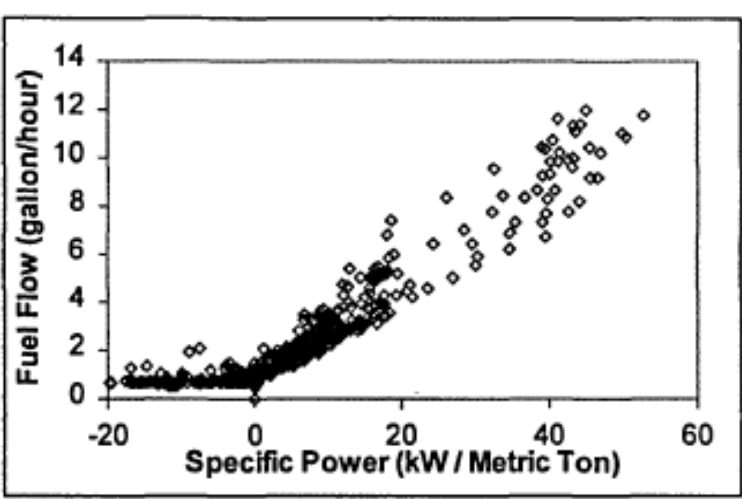

(b)

Figura 8 - Consumo de combustível do motor em função da (a) aceleração e (b) VSP para ciclos FTP e HL07 (Jimenez-Palacios, 1999).

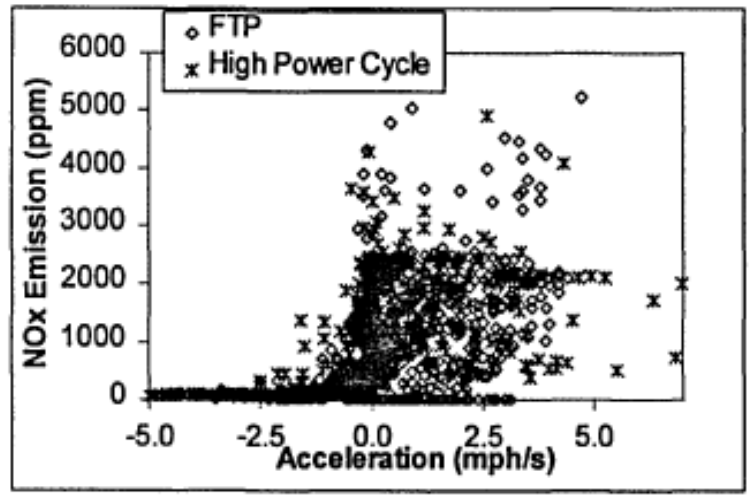

(a)

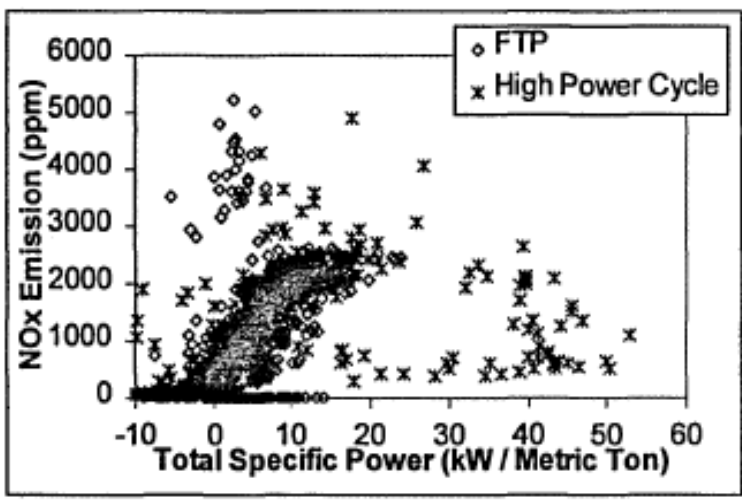

(b)

Figura 9 - Emissões de NOx na saída do motor em função da (a) aceleração e (b) VSP para ciclos FTP e HL07 (Jimenez-Palacios, 1999).

Duas das principais vantagens da utilização do VSP como uma variável de estudo de emissões segundo Jimenez-Palacios (1999) são:

- Ser diretamente mensurável. Nenhuma informação ou hipótese sobre qualquer parâmetro que não possa ser medido diretamente na operação é necessária para o cálculo do VSP em um nível de precisão aceitável.

- Identificar parte significativa da dependência das emissões em relação aos parâmetros de operação do motor, pois há relação direta com a taxa ar/combustível. Além disso, a definição de potência específica considera efeitos da resistência à rolagem, arrasto aerodinâmico e inclinação da via, que podem aumentar as emissões em até duas vezes. 
Jimenez-Palacios (1999) define que a potência instantânea iguala-se ao produto da velocidade e uma aceleração equivalente, a qual inclui os efeitos citados no parágrafo anterior (inclinação da via e da resistência à rolagem), mais uma parcela do arrasto aerodinâmico, que é proporcional ao cubo da velocidade instantânea.

O conceito básico de VSP vem sendo aplicado amplamente em diversos estudos e em diferentes formas e tem se mostrado um parâmetro útil para estimar emissões. A agência de proteção ambiental dos Estados Unidos EPA (Environmental Protection Agency) desenvolve e dissemina esses conceitos no desenvolvimento dos ciclos de condução e para estimar emissões no MOVES (Motor Vehicle Emission Simulator Simulador de emissões de veículos a motor) (Estados Unidos, 2009).

Apesar de o VSP não ter sido desenvolvido especificamente para a aplicação em veículos pesados, Zhai et al.(2008) propõem sua aplicação para desenvolver taxas de emissões médias de VSP para ônibus urbanos movidos a diesel.

Desta forma, partindo dos mesmos conceitos apresentados por Jimenez-Palacios (1999), Zhai et al. (2008) e Estados Unidos (2009) aplicam, para as variáveis da equação do VSP, valores típicos de ônibus urbanos a diesel, que também serão utilizados neste trabalho conforme a equação 2 : 
$V S P=v \times(a+g \times \sin (\phi)+\psi)+\zeta \times v^{3}$

onde:

- $\quad V S P=$ Potência específica veicular (Vehicle Specific Power, $k W / t)$;

- $\quad v=$ velocidade $(\mathrm{m} / \mathrm{s})$;

- $\quad a=$ aceleração do veículo $\left(\mathrm{m} / \mathrm{s}^{2}\right)$;

- $g=$ aceleração da gravidade, $9,81 \mathrm{~m} / \mathrm{s}^{2}$;

- $\phi=$ inclinação da via (adimensional, em radianos);

- $\psi=$ coeficiente de resistência à rolagem (adimensional);

- $\zeta=$ termo do coeficiente de arrasto $\left(\mathrm{em} \mathrm{m}^{-1}\right)$.

- $\zeta=\rho_{\mathrm{a}} \times\left(\mathrm{C}_{\mathrm{D}} \times \mathrm{A} / \mathrm{m}\right)$

onde:

- $\rho_{\mathrm{a}}=$ Densidade do ar $\left(\mathrm{em} \mathrm{kg} / \mathrm{m}^{3}\right)$;

- $C_{D}=$ Coeficiente de arrasto (adimensional);

- $A=$ Área frontal do veículo $\left(\mathrm{em} \mathrm{m}^{2}\right)$;

- $m=$ Massa do veículo (em kg). 


\subsection{EMISSÕES VEICULARES EM MOTORES DIESEL}

O motor diesel, como qualquer outro motor à combustão, converte energia química contida no combustível em energia mecânica. O combustível diesel é uma mistura de hidrocarbonetos que teoricamente produz somente dióxido de carbono $\left(\mathrm{CO}_{2}\right)$, vapor d'água $\left(\mathrm{H}_{2} \mathrm{O}\right)$ e uma fração do ar aspirado não utilizado durante sua combustão. Com exceção do $\mathrm{CO}_{2}$, por ser gás do efeito estufa, os demais produtos da combustão do diesel não produzem efeitos nocivos ao ambiente (Majewski e Khair, 2006).

Para Tsolakis e Megaritis (2004), os percentuais dos principais reagentes (oxigênio e vapor d'água) nos gases de escape do motor dependem das condições de operação (por exemplo, taxa ar/combustível). Para o motor a diesel o efeito da taxa de ar e combustível $(\lambda)$ na composição dos gases de escape pode ser visto na reação de combustão, mostrada na equação 3 :

$$
\mathrm{C}_{n} \mathrm{H}_{1,88 n}+1,47 n \lambda\left(\mathrm{O}_{2}+79 / 21 \mathrm{~N}_{2}\right) \rightarrow n \mathrm{CO}_{2}+0,94 n \mathrm{H}_{2} \mathrm{O}+1,47 n(\lambda-1) \mathrm{O}_{2}+1,47 n \lambda(79 / 21) \mathrm{N}_{2}
$$

onde $n$ é o número de átomos de carbono na molécula do combustível (Tsolakis e Megaritis, 2004).

Motores diesel operam convencionalmente sob condições de mistura pobre $(\lambda>1)$ e as emissões do motor sempre contêm oxigênio, como pode ser visto equação 3 . Ao se aproximar de uma operação estequiométrica $(\lambda=1)$, o percentual de vapor d'água nos gases de escape aumenta, enquanto o oxigênio diminui (Tsolakis e Megaritis, 2004).

$\mathrm{Na}$ prática, as emissões de poluentes de escapamento decorrem da queima incompleta dos combustíveis ou lubrificantes pelo motor, compreendendo uma série de substâncias como monóxido de carbono (CO), dióxido de carbono $\left(\mathrm{CO}_{2}\right)$, hidrocarbonetos $(\mathrm{HC})$, aldeídos $(\mathrm{RCHO})$, óxidos de nitrogênio (NOx) e material particulado (MP) (Brasil, 2011).

Nos motores de combustão interna as emissões de poluentes mais problemáticas são a formação de material particulado e óxidos de nitrogênio. Os níveis de 
emissões desses poluentes são os aspectos mais críticos para o cumprimento das resoluções mais recentes. O principal problema consiste na redução simultânea das emissões de MP e NOx pois as estratégias para reduzir um destes resulta imediatamente no aumento do outro (López et al., 2008).

As emissões de um veículo automotor podem ocorrer pelo escapamento (emissões diretas) ou podem ser de natureza evaporativa do combustível, aparecendo durante o uso e o repouso do veículo. São influenciadas por vários fatores, dentre os quais pode-se destacar: tecnologia do motor, porte e tipo de uso do veículo, idade do veículo, projeto e materiais do sistema de alimentação de combustível, tipo e qualidade do combustível, condições de manutenção e condução, além de fatores meteorológicos (pressão e temperatura ambientes) (Brasil, 2011).

Além dos elementos citados acima, segundo Majewski e Khair (2006), as emissões dependem de fatores adicionais, tais como:

- Aceleração, para emissões de CO, HC e MP. Verificam-se emissões de MP de 30 a 50\% maiores em operações transientes comparando com estacionárias.

- Velocidade e carga do veículo são reconhecidas como fatores críticos que influenciam emissões.

- Carregamentos auxiliares no motor, como ar condicionado, equipamentos de ventilação ou aquecimento, podem gerar emissões adicionais que não são consideradas para a maioria dos ciclos de testes.

- Fatores relacionados diretamente ao condutor que afetam emissões incluem a suavidade das acelerações e a velocidade constante. Estudos mostraram que uma condução agressiva que corresponda a apenas $2 \%$ do tempo pode produzir até $40 \%$ das emissões.

- Fatores relacionados às vias não são considerados para ciclos de testes para homologação, ou seja, em geral consideram-se vias planas. 
Veículos pesados vêm obtendo reduções significativas nas emissões de poluentes, especialmente na Europa e América do Norte. Para alcançar requisitos cada vez mais restritivos, os fabricantes de veículos terão de implantar medidas de redução relativas ao motor e/ou tecnologias de pós-tratamento de gases de escape para controlar emissões. Como outra solução, os fabricantes podem optar pela queima de combustíveis alternativos tais como o gás natural (Clark et al., 2007).

A Figura 10 mostra a evolução das regulamentações de emissões na Europa e nos Estados Unidos, que estão neste momento à frente da Europa no que diz respeito às regulamentações de emissões para veículos pesados, sendo que a regulamentação europeia Euro 6 deve ser implantada em duas fases em 2013 e 2014.

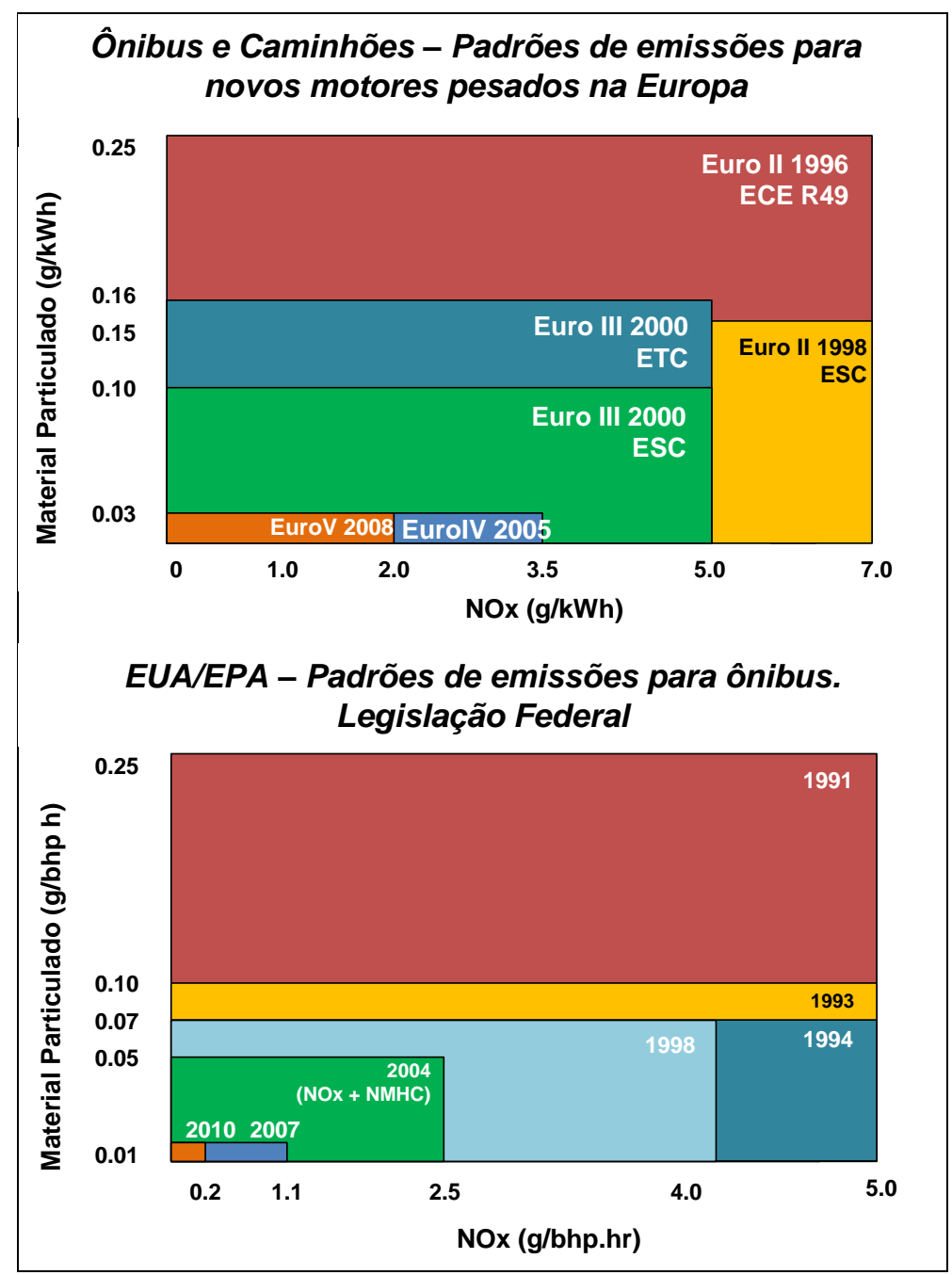

Figura 10 - Evolução das regulamentações de emissões para veículos pesados na Europa (Euro) e Estados Unnidos (EPA) (Clark et al., 2007). 
Para o Brasil, a regulamentação de emissões de poluentes para veículos pesados, em vigor a partir de janeiro de 2012, P7, é equivalente à norma europeia Euro V. A evolução das fases do PROCONVE (Programa de Controle da Poluição por Veículos Automotores), para veículos pesados, pode ser verificada na Tabela 2. As emissões medidas em um motor são exibidas em termos de massa de poluente por unidade de trabalho, expressas em g/kWh (Brasil, 2011).

Tabela 2 - Fatores de emissão de poluentes principais em motores diesel por fase do PROCONVE, em g/kWh (Brasil, 2011).

\begin{tabular}{ccccc}
\hline Fase do PROCONVE & $\begin{array}{c}\text { CO } \\
\text { Monóxido de Carbono }\end{array}$ & $\begin{array}{c}\text { NMHC } \\
\text { Hidrocarbonetos não-metano }\end{array}$ & $\begin{array}{c}\text { NOx } \\
\text { Óxidos de Nitrogênio }\end{array}$ & $\begin{array}{c}\text { MP* }^{*} \\
\text { Material Particulado }\end{array}$ \\
\hline Pré-PROCONVE, P1 e P2 (1990-1993) & 1,86 & 0,68 & 10,7 & 0,660 \\
P3 (1994) & 1,62 & 0,54 & 6,55 & 0,318 \\
P4 (1998) & 0,85 & 0,29 & 6,16 & 0,120 \\
P5 (2003) & 0,83 & 0,16 & 4,67 & 0,078 \\
P7 (2012) & 0,83 & 0,16 & 1,8 & 0,018 \\
\hline
\end{tabular}

$\left(^{*}\right)$ Valor válido para teor de enxofre no diesel utilizado no ensaio de homologação

Por fim, espera-se que a combinação do conceito de VSP com um método de seleção de microviagens para a construção de ciclos de condução conforme a proposta apresentada por Lai et al. (2012) poderá conduzir a resultados mais representativos em termos de emissões. Portanto, essa será a metodologia aplicada na execução do experimento exposto nos próximos capítulos deste trabalho. 


\section{METODOLOGIA}

O trabalho está dividido em quatro etapas básicas, sendo elas a aquisição e a análise de dados (principalmente a variação de velocidade no tempo), a construção dos ciclos de condução e por fim a estimativa das emissões para os ciclos desenvolvidos.

\subsection{AQUISIÇÃO DE DADOS: DESCRIÇÃO DO EXPERIMENTO}

A primeira etapa, a aquisição de dados, foi realizada através de um experimento com um ônibus urbano, onde foram executadas medições de diversas variáveis relevantes para a construção de ciclos de condução e cálculo do VSP, principalmente posicionamento e velocidade, com auxílio de receptor GPS (Global Positioning System - Sistema de posicionamento global) e um data logger, equipamento eletrônico para gravação de dados adquiridos com GPS, para armazenar informações das rotas percorridas.

Os registros gravados foram pré-processados para verificar a existência de falhas na gravação, encontradas principalmente nos dados obtidos pelo receptor GPS, tais como arquivos corrompidos ou sem gravação, registros de posicionamento e velocidade inconsistentes (posição incompatível com o experimento, velocidades excessivas não passíveis de serem obtidas com o veículo de testes), entre outros.

A partir de um percurso completo preexistente, de aproximadamente $150 \mathrm{~km}$, percorridos em um teste de durabilidade veicular urbana, foram selecionados segmentos do trajeto que pudessem representar diferentes condições de operação de ônibus urbanos na região metropolitana de São Paulo, incluindo vias dos municípios de Santo André, São Bernardo do Campo, São Caetano, Diadema e Mauá. O percurso completo é composto por vias de diferentes características geométricas e de operação, com velocidade máxima permitida de $60 \mathrm{~km} / \mathrm{h}$, sendo que cerca de $80 \%$ é percorrido em avenidas com limite acima de $50 \mathrm{~km} / \mathrm{h}$ e o restante em vias com limite de velocidade inferior a esse valor. 
Apesar de o trajeto completo do experimento ser composto também por vias dotadas de corredor de circulação exclusiva de ônibus, o veículo em teste não circulou nestes corredores por falta de autorização dos órgãos gestores, ficando sua circulação nestas vias restrita às faixas compartilhadas com os demais veículos, inclusive outros ônibus.

As vias percorridas durante o percurso completo são em sua maioria, aproximadamente $70 \%$, ruas e avenidas com boa condição de pavimentação, enquanto o restante possui condições regulares ou com muitas imperfeições, mas não há vias sem pavimento.

O percurso total é composto por cerca de 340 paradas (aprox. 2,3 paradas por quilômetro) em pontos de ônibus. Durante cada parada o veículo abre e fecha as portas e volta a acelerar, sem que haja um tempo de espera para a simulação da movimentação dos passageiros, o que não é a condição real. Este fato distancia o experimento da realidade, porém em comparação com a literatura (Lai et al., 2012 em Pequim, China) o tempo médio de parada se aproxima muito dos valores medidos no experimento, conforme a Tabela 3.

Tabela 3 - Tempo médio de paradas - Comparativo do experimento e Lai et al. (2012).

\begin{tabular}{lc}
\hline \multicolumn{1}{c}{ Referência } & $\begin{array}{c}\text { Tempo médio parado } \\
\text { s }\end{array}$ \\
\hline Linhas regulares (experimento) & 25,2 \\
$\begin{array}{l}\text { BRT (Bus Rapid Transit - Corredor } \\
\text { de ônibus) (Lai et al ., 2012) }\end{array}$ & 21,0 \\
Linhas Expressas (Lai et al. , 2012) & 25,0 \\
Linhas Regulares (Lai et al. , 2012) & 25,0 \\
\hline
\end{tabular}

Zhai et al. (2008), Jimenez-Palácios (1999), entre outros, sugerem que para estimar emissões a medição de velocidade pode ser feita em intervalos de um segundo (1 $\mathrm{Hz}$ ), o que é possível com diversos equipamentos disponíveis no mercado, sendo que alguns deles têm capacidade de gravação de dados de até $100 \mathrm{~Hz}$. Para a 
elaboração deste trabalho foi utilizada, portanto, a frequência usual de $1 \mathrm{~Hz}$ para a gravação dos dados.

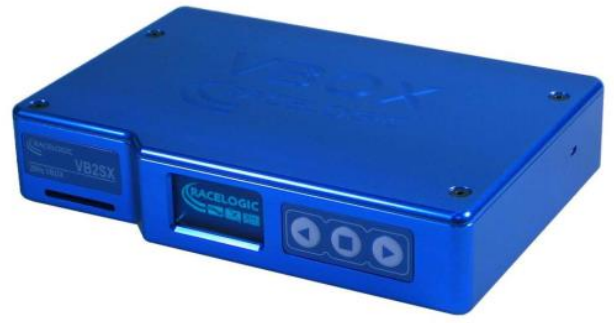

(a)

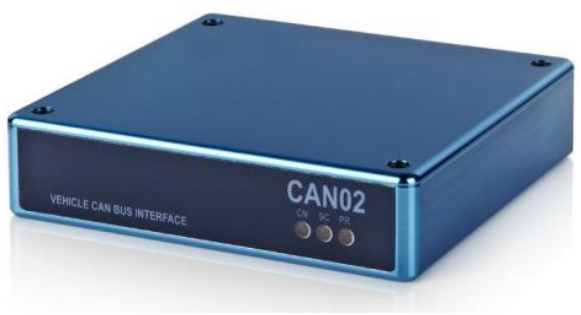

(b)

Figura 11 - Módulos Racelogic (a) VBOX e (b) CAN02 utilizados para aquisição e gravação de dados no experimento (Racelogic, 2012a).

A Figura 11 mostra os equipamentos utilizados durante a realização dos testes: Racelogic VBOX VB2SX, que é um receptor de sinais GPS combinado com um data logger para gravação de dados em até $20 \mathrm{~Hz}$, em conjunto com o módulo Racelogic CAN02, que obtém dados diretamente da ECU (Engine Central Unit - central eletrônica do motor) via comunicação CAN (Controller Area Network), que é o protocolo de comunicação eletroeletrônica, e repassa os dados para gravação no cartão de memória inserido no VBOX. O esquema de funcionamento combinado dos equipamentos utilizados no experimento é ilustrado na Figura 12.

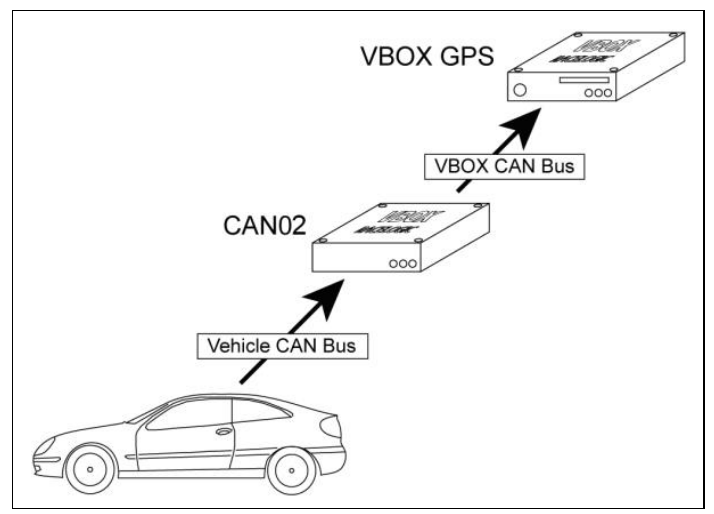

Figura 12 - Esquema de funcionamento dos equipamentos em conjunto (Racelogic, 2012b).

O conjunto de equipamentos VBOX e CAN02 adquire e salva os dados em arquivo com extensão específica (.VBO), que em seguida são convertidos em planilha excel, conforme o fluxo apresentado na Figura 13. 


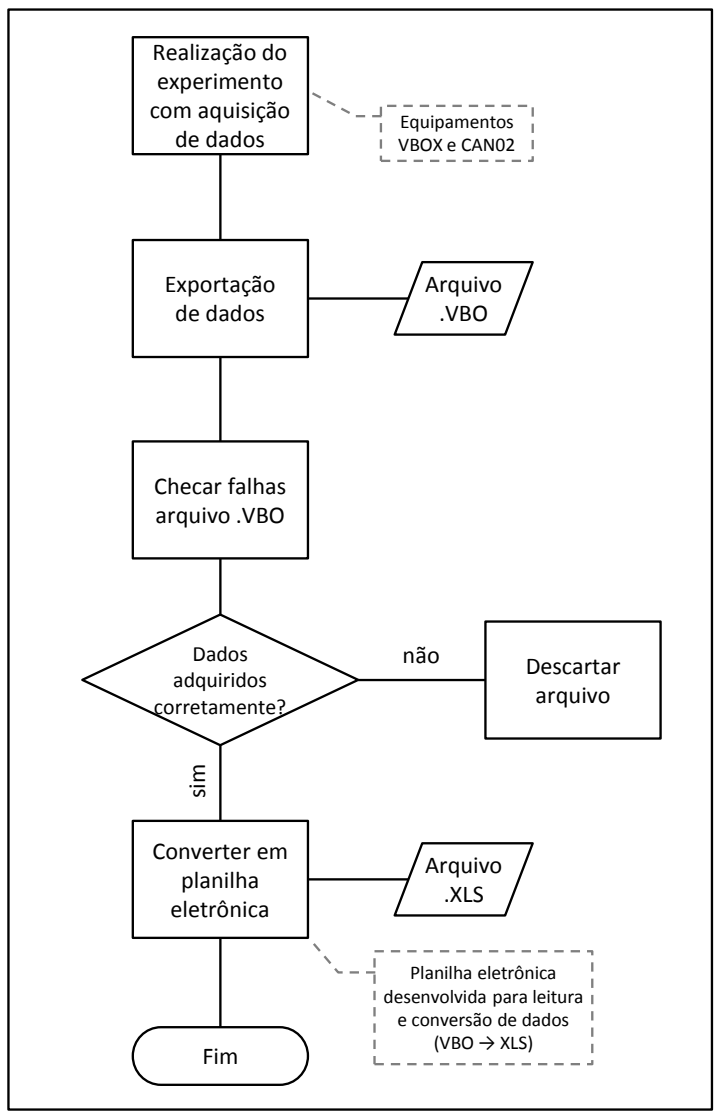

Figura 13 - Fluxograma do procedimento de aquisição de dados com os equipamentos VBOX e CAN02.

Exemplos dos dados adquiridos durante o experimento são mostrados na Figura 14, com destaque para as informações mais relevantes para o desenvolvimento de ciclos de condução como o tempo, as coordenadas geográficas e a velocidade instantânea adquirida pelo módulo eletrônico do veículo (VCAN ou velocidade CAN) e pelo receptor GPS (VGPS ou velocidade GPS), além da elevação e inclinação, importantes para o cálculo do VSP.

Além destas informações básicas para a construção dos ciclos adquiridas pelo receptor GPS, com auxílio do módulo CAN02 dados adicionais da central eletrônica do veículo foram registrados pelo data logger, como, por exemplo, rotação do motor, torque instantâneo, abertura de portas, informações da caixa de transmissão, entre outros. 


\begin{tabular}{|c|c|c|c|c|c|c|c|c|c|c|c|c|c|}
\hline 4 & A & B & c & D & E & H & $\mathrm{J}$ & $\mathrm{K}$ & M & Q & $\mathrm{R}$ & $s$ & $\mathrm{~T}$ \\
\hline 1 & Hora & Latitude & Longitude & Velocidade GPS & Elevação & Rotação motor & Hodômetro dia & Torque motor & Velocidade CAN & Dia & Mês & Relação câmbio & Stat_door \\
\hline 2 & & & & $\mathrm{~km} / \mathrm{h}$ & $\mathrm{m}$ & RPM & $\mathrm{km}$ & $\mathrm{Nm}$ & $\mathrm{km} / \mathrm{h}$ & & & & \\
\hline 156 & 101332 & $-23,62730733$ & $-46,6192446$ & 26,5 & 788,820 & 1883 & 38,4 & 280 & 26,7 & 30 & 10 & 2,7 & 1 \\
\hline 157 & 101333 & $-23,62737283$ & $-46,619244$ & 26,3 & 788,820 & 1916 & 38,4 & 220 & 26,9 & 30 & 10 & 2,8 & 1 \\
\hline 158 & 101334 & $-23,62743913$ & $-46,6192427$ & 26,8 & 788,830 & 1927 & 38,4 & 246 & 27,0 & 30 & 10 & 2,8 & 1 \\
\hline 159 & 101335 & $-23,62750542$ & $-46,6192399$ & 26,6 & 788,820 & 1927 & 38,4 & 233 & 27,0 & 30 & 10 & 2,8 & 1 \\
\hline 160 & 101336 & $-23,6275709$ & $-46,6192343$ & 26,3 & 788,780 & 1917 & 38,5 & 180 & 27,1 & 30 & 10 & 2,8 & 1 \\
\hline 161 & 101337 & $-23,62763813$ & $-46,6192236$ & 27,7 & 788,820 & 1947 & 38,5 & 452 & 27,4 & 30 & 10 & 2,8 & 1 \\
\hline 162 & 101338 & $-23,62770683$ & $-46,6192073$ & 28,4 & 788,830 & 2058 & 38,5 & 361 & 28,8 & 30 & 10 & 2,8 & 1 \\
\hline 163 & 101339 & $-23,6277771$ & $-46,619189$ & 29,1 & 788,710 & 2075 & 38,5 & 319 & 29,1 & 30 & 10 & 2,8 & 1 \\
\hline 164 & 101340 & $-23,62784807$ & $-46,619171$ & 29,2 & 788,400 & 1967 & 38,5 & 212 & 27,7 & 30 & 10 & 2,8 & 1 \\
\hline 165 & 101341 & $-23,62791772$ & $-46,6191523$ & 28,5 & 788,300 & 2008 & 38,5 & 307 & 28,1 & 30 & 10 & 2,8 & 1 \\
\hline 166 & 101342 & $-23,62798457$ & $-46,6191304$ & 27,6 & 788,290 & 2046 & 38,5 & 298 & 28,8 & 30 & 10 & 2,8 & 1 \\
\hline 167 & 101343 & $-23,62804953$ & $-46,6191059$ & 27,5 & 788,440 & 2016 & 38,5 & 244 & 28,3 & 30 & 10 & 2,8 & 1 \\
\hline 168 & 101344 & $-23,62811222$ & $-46,6190795$ & 26,7 & 788,800 & 1977 & 38,5 & 0 & 27,6 & 30 & 10 & 2,8 & 1 \\
\hline 169 & 101345 & $-23,62817612$ & $-46,6190531$ & 27,8 & 789,080 & 1946 & 38,5 & 373 & 27,2 & 30 & 10 & 2,8 & 1 \\
\hline 170 & 101346 & $-23,62823997$ & $-46,6190273$ & 26,9 & 789,330 & 1987 & 38,5 & 7 & 28,4 & 30 & 10 & 2,7 & 1 \\
\hline 171 & 101347 & $-23,62830275$ & $-46,6190022$ & 26,7 & 789,570 & 1971 & 38,5 & 0 & 27,6 & 30 & 10 & 2,8 & 1 \\
\hline 172 & 101348 & $-23,6283642$ & $-46,6189784$ & 26,0 & 789,710 & 1870 & 38,5 & 0 & 26,4 & 30 & 10 & 2,8 & 1 \\
\hline 173 & 101349 & $-23,6284227$ & $-46,618956$ & 24,4 & 790,000 & 1805 & 38,6 & 0 & 25,6 & 30 & 10 & 2,8 & 1 \\
\hline 174 & 101350 & $-23,62848115$ & $-46,6189415$ & 23,2 & 789,220 & 1700 & 38,6 & 0 & 23,7 & 30 & 10 & 2,8 & 1 \\
\hline 175 & 101351 & $-23,62854007$ & $-46,6189304$ & 23,8 & 788,500 & 1621 & 38,6 & 0 & 22,6 & 30 & 10 & 2,8 & 1 \\
\hline 176 & 101352 & $-23,62859887$ & $-46,6189179$ & 23,9 & 788,280 & 1642 & 38,6 & 324 & 22,6 & 30 & 10 & 2,8 & 1 \\
\hline 177 & 101353 & $-23,62865342$ & $-46,6189003$ & 22,2 & 788,610 & 1639 & 38,6 & 0 & 23,0 & 30 & 10 & 40,5 & 1 \\
\hline 178 & 101354 & $-23,62870738$ & $-46,6188836$ & 22,0 & 788,580 & 1529 & 38,6 & 0 & 21,6 & 30 & 10 & 40,5 & 1 \\
\hline 179 & 101355 & $-23,62876068$ & $-46,6188695$ & 21,3 & 788,500 & 1409 & 38,6 & 0 & 19,8 & 30 & 10 & 40,5 & 1 \\
\hline 180 & 101356 & $-23,62881283$ & $-46,6188543$ & 21,3 & 788,740 & 1392 & 38,6 & 442 & 19,7 & 30 & 10 & 40,5 & 1 \\
\hline 181 & 101357 & $-23,62886553$ & $-46,6188374$ & 22,2 & 788,730 & 1497 & 38,6 & 330 & 20,5 & 30 & 10 & 40,5 & 1 \\
\hline 182 & 101358 & $-23,62892143$ & $-46,6188171$ & 24,3 & 788,860 & 1652 & 38,6 & 780 & 23,0 & 30 & 10 & 40,5 & 1 \\
\hline 183 & 101359 & $-23,62898505$ & $-46,6187933$ & 28,2 & 789,050 & 1896 & 38,6 & 780 & 26,3 & 30 & 10 & 2,8 & 1 \\
\hline 184 & 101400 & $-23,62905565$ & $-46,618766$ & 30,7 & 789,120 & 2190 & 38,6 & 780 & 30,2 & 30 & 10 & 40,5 & 1 \\
\hline 185 & 101401 & $-23,62912972$ & $-46,6187361$ & 32,2 & 789,410 & 1692 & 38,6 & 447 & 30,6 & 30 & 10 & 40,5 & 1 \\
\hline 186 & 101402 & $-23,62920702$ & $-46,6187066$ & 33,2 & 789,290 & 1492 & 38,6 & 397 & 32,4 & 30 & 10 & 40,5 & 1 \\
\hline 187 & 101403 & $-23,62928647$ & $-46,6186768$ & 34,0 & 789,100 & 1562 & 38,6 & 549 & 33,7 & 30 & 10 & 40,5 & 1 \\
\hline 188 & 101404 & $-23,62936598$ & $-46,6186431$ & 34,4 & 789,340 & 1586 & 38,7 & 394 & 34,3 & 30 & 10 & 1,8 & 1 \\
\hline 189 & 101405 & $-23,6294454$ & $-46,61860458$ & 35,2 & 789,890 & 1618 & 38,7 & 379 & 35,1 & 30 & 10 & 1,8 & 1 \\
\hline 190 & 101406 & $-23,62952583$ & $-46,61856063$ & 36,6 & 790,430 & 1658 & 38,7 & 553 & 35,8 & 30 & 10 & 1,8 & 1 \\
\hline 191 & 101407 & $-23,62960862$ & $-46,61851202$ & 38,2 & 790,940 & 1757 & 38,7 & 673 & 38,1 & 30 & 10 & 1,8 & 1 \\
\hline 192 & 101408 & $-23,62969258$ & $-46,61846170$ & 38,6 & 791,430 & 1783 & 38,7 & 297 & 38,8 & 30 & 10 & 1,8 & 1 \\
\hline
\end{tabular}

Figura 14 - Exemplo de planilha com dados adquiridos pelo GPS e salvos pelo data logger em $1 \mathrm{~Hz}-$ em destaque tempo, coordenadas geográficas, velocidade GPS e elevação.

Com a possibilidade de obter informações diretamente da ECU do veículo, dados do comportamento do motor e veículo foram armazenados a cada instante na frequência estabelecida de $1 \mathrm{~Hz}$ e, assim, puderam ser gravadas informações como a velocidade do veículo indicada no painel de instrumentos, que será tratada como VCAN ou velocidade CAN, que é uma informação menos suscetível a falhas do que a registrada pelo receptor GPS.

Para a realização do experimento proposto foi utilizado um ônibus urbano durante a execução de testes de durabilidade em um trajeto fixo descrito anteriormente, com as características a seguir:

- Modelo Mercedes-Benz OF1721 Euro5 com carroceria do tipo básico, conforme NBR15570 (ABNT, 2011), Figura 15(a); 
- Motor MB OM924LA (Euro5 / Proconve P-7), 153kW (208cv), 780Nm, câmbio mecânico MB G-85 de 6 marchas sincronizadas;

- PBT (peso bruto total) de 17 toneladas;

- Capacidade para até 85 passageiros (a carga no veículo foi simulada com tanques de água e barris de areia, como mostra a Figura 15(b)).

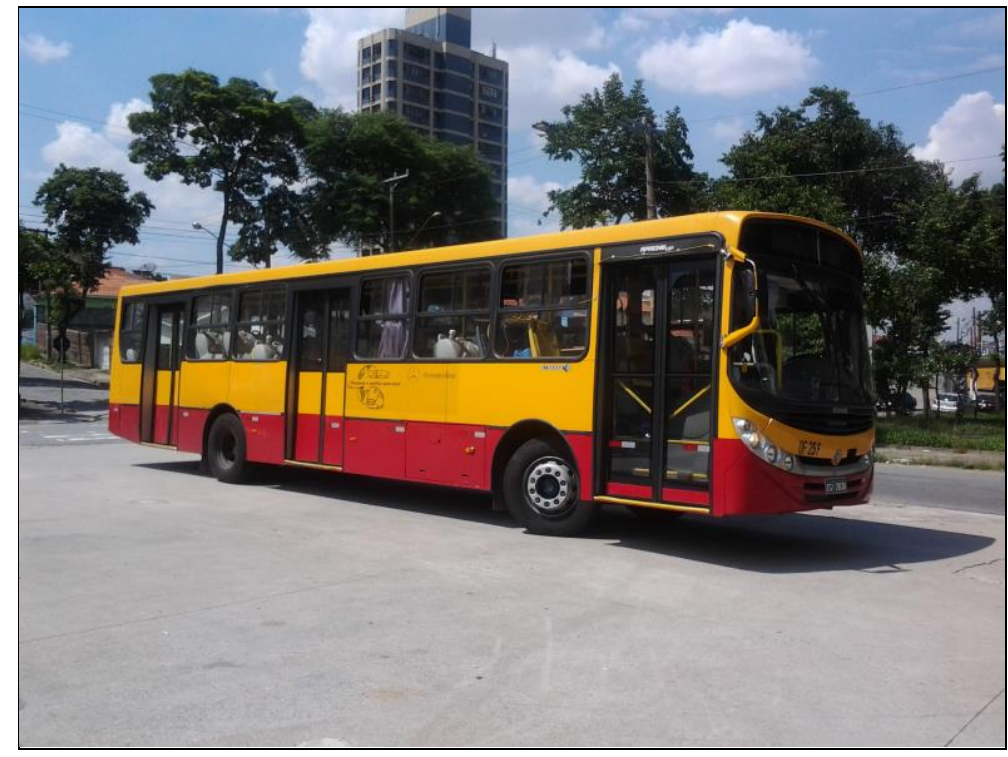

(a)

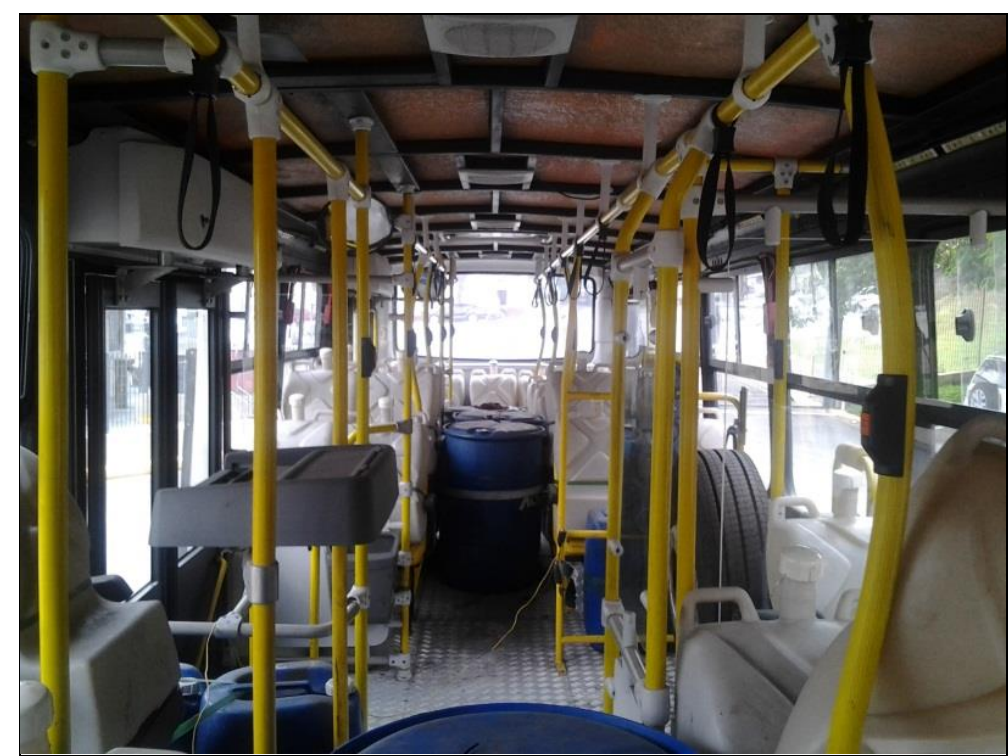

(b)

Figura 15 - Ônibus urbano modelo Mercedes-Benz OF1721 Euro5 utilizado no experimento. (a) Visão geral e (b) interior do veículo com exemplo de carga utilizada. 
Os equipamentos de medição e armazenamento de dados foram instalados de maneira que pudessem ser facilmente acessados, atrás do posto do motorista, como mostrado na Figura 16, sendo que na primeira fase a antena do receptor GPS ficou instalada sobre o painel de instrumentos (no detalhe da Figura 16) e na segunda fase foi instalada sobre o teto do veículo. O posicionamento da antena foi fator decisivo para a divisão do experimento em duas fases, pois foi verificado que a precisão da medida de velocidade adquirida do GPS foi diretamente afetada por essa razão.

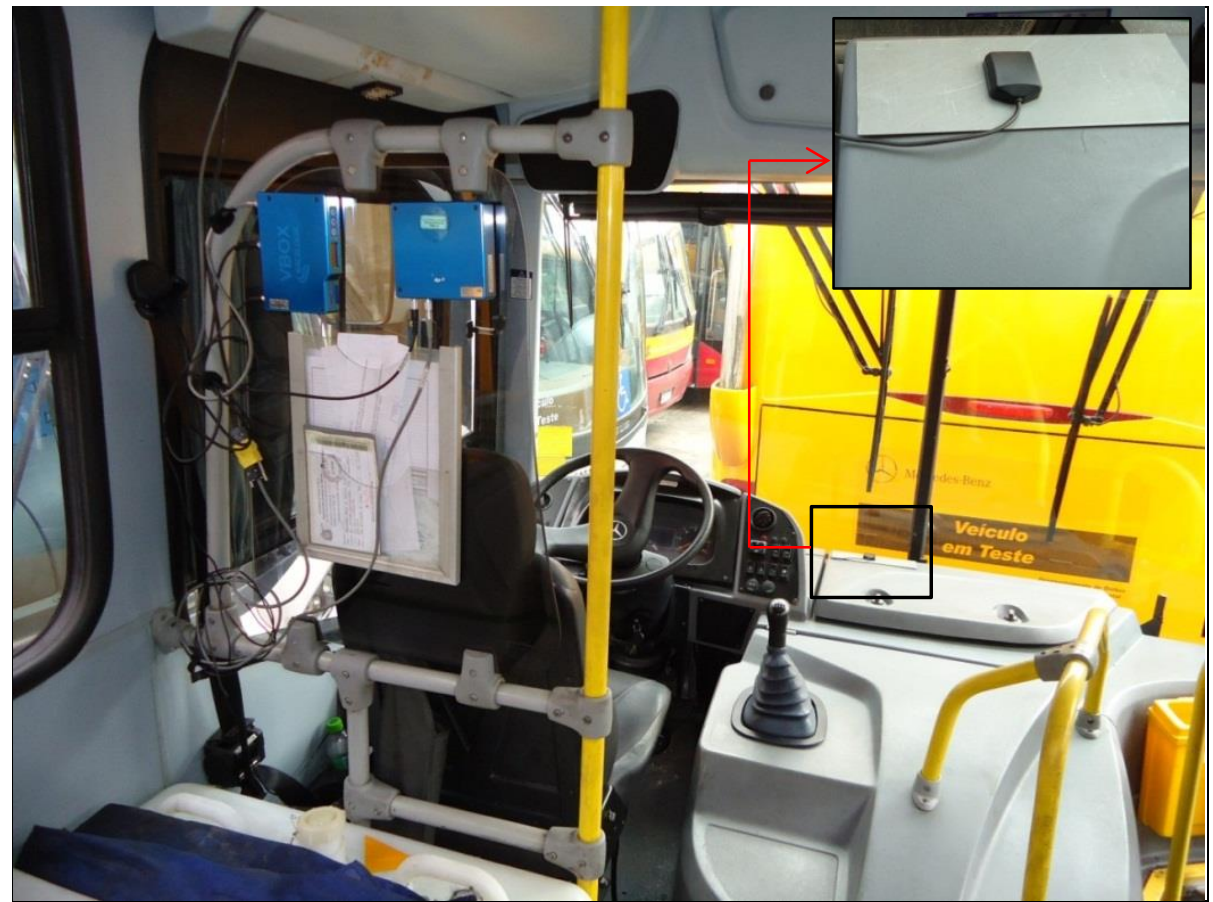

Figura 16 - Instalação dos equipamentos de medição no ônibus de testes. No detalhe do canto direito superior, posicionamento da antena na fase 01 .

O experimento foi dividido em duas fases. Na primeira e mais longa, foi considerado como registro de velocidade apenas os dados da ECU (velocidade VCAN), garantindo, assim, que os valores de velocidade utilizados possuam precisão mais controlada na maior parte dos testes (dependente apenas de características e comportamento do veículo como tamanho do pneu, perda de aderência, entre outros). Além disso, dessa maneira a medição independe de fatores externos que podem produzir falhas na recepção dos sinais GPS, como condições meteorológicas, devido à topografia ou "sombras" produzidas por regiões com muitos edifícios ou árvores. 
Antes do início do experimento válido para este trabalho foram realizados testes com a antena posicionada sobre o painel de instrumentos, e os resultados preliminares apresentaram altos índices de correlação entre os valores da velocidade adquirida pelo receptor GPS (velocidade VGPS) e os valores de velocidade registrados pela central eletrônica do veículo (VCAN).

Desta forma, pela possibilidade do motorista observar o correto posicionamento da antena, pelo seu fácil acesso e visualização, decidiu-se manter durante todo o experimento o equipamento sobre o painel de instrumentos.

Entretanto, após o encerramento dos testes foram constatadas diversas incompatibilidades entre as medições de velocidade VGPS e VCAN o que tornou a velocidade adquirida pelo receptor GPS uma medida não confiável, tornando a VCAN a referência para todos os cálculos que envolvessem essa variável durante a primeira fase do experimento.

Porém, após essa constatação ficou decidido que seria realizada uma segunda fase do experimento com a antena posicionada sobre o teto do veículo, mas para isso, antes de cada "volta" no circuito completo o motorista deveria checar a posição e reforçar a fixação do equipamento.

A segunda fase do experimento foi definida como uma etapa de verificação, para comparar as fontes de medida de velocidade VGPS e VCAN e a influência destes valores no cálculo do VSP. Devido à disponibilidade do veículo de testes, a segunda fase foi realizada em apenas um dia.

\subsubsection{Experimento Fase 1 - Antena posicionada no painel do veículo}

A fase 1 do experimento foi realizada entre os dias 21/09 (sexta-feira) e 01/11/2012 (quinta-feira), apenas em dias úteis, de forma interrupta, de acordo com a disponibilidade do veículo e sem que houvesse prejuízo aos testes de durabilidade que estavam sendo executados.

Nesta fase foram coletados 17632 minutos (aprox. 294h) de dados considerados válidos, em 24 dias de testes, realizados por dois motoristas ( $\mathrm{A}$ e B) operando em 
horário definido e percurso fixo, sendo que a distribuição total de horas por dia da semana pode ser verificada na Figura 17. As horas apontadas no sábado referem-se à finalização de testes iniciados na sexta-feira anterior.

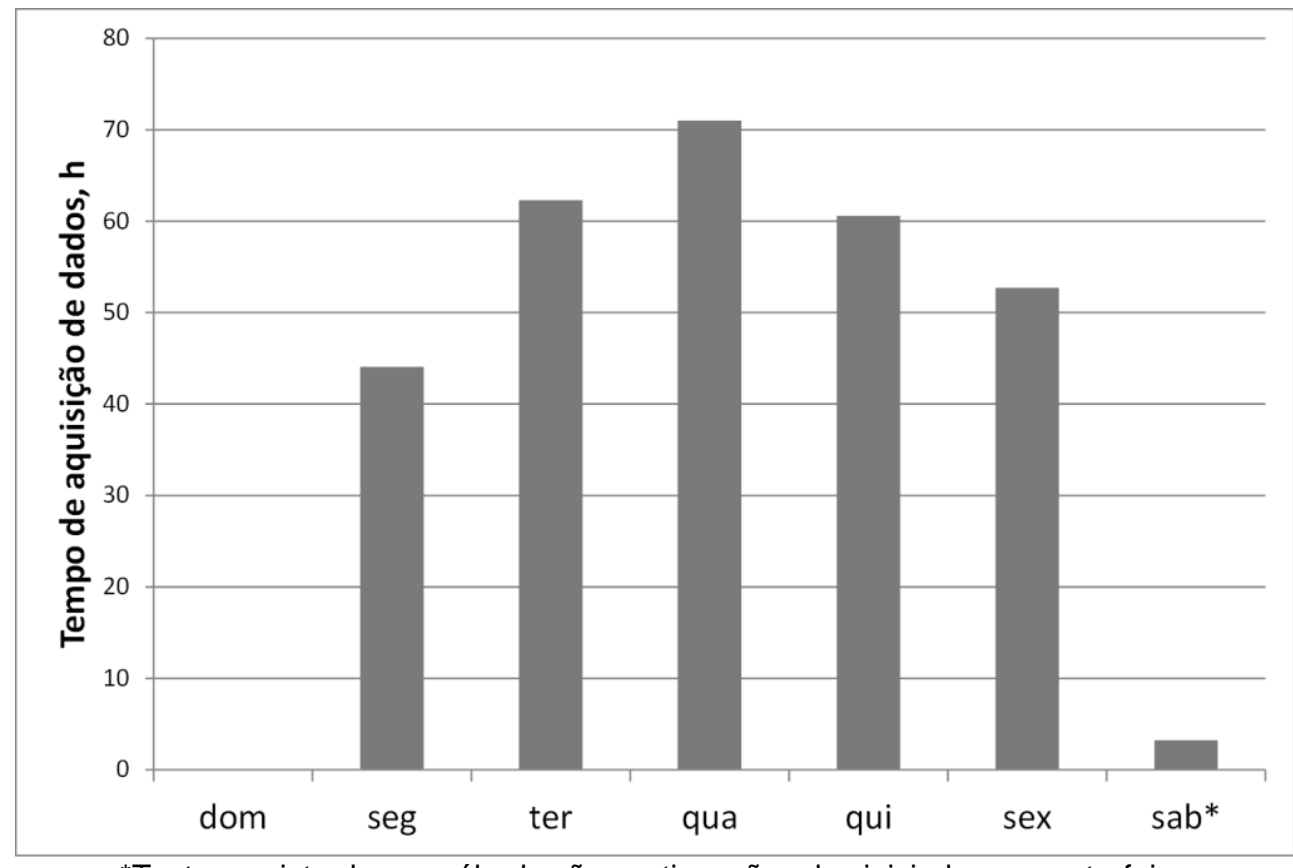

*Testes registrados no sábado são continuações dos iniciados na sexta-feira.

Figura 17 - Distribuição de horas de testes por dia da semana na primeira fase do experimento.

A realização dos testes foi dividida em dois turnos com um motorista cada, sendo que o primeiro, com motorista $A$, deveria ocorrer das 6:00 às 14:30 e o segundo, com motorista $B$, planejado para ocorrer das 15:00 às 23:30. Entretanto, como existiram influências externas que não puderam ser controladas, como tráfego por exemplo, esses horários serviram como referência e foram alterados de acordo com a necessidade. Na Figura 18, está o percentual de testes executado pelos motoristas A e B durante a primeira fase. 


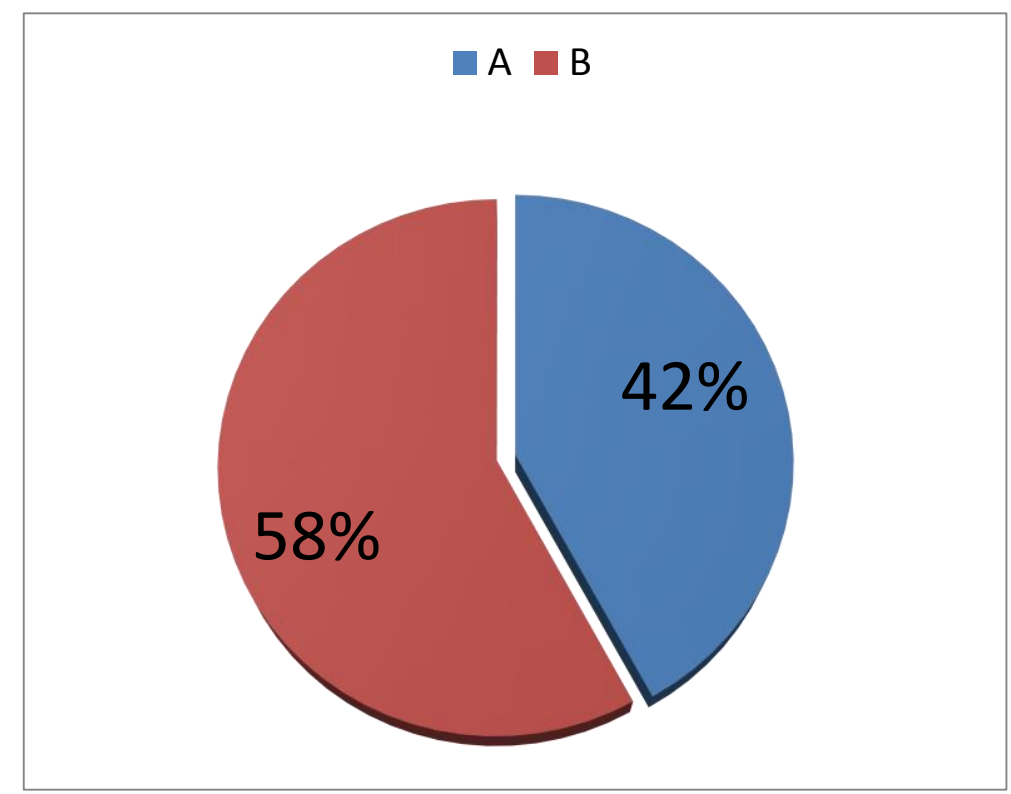

Figura 18 - Distribuição dos testes por motorista na primeira fase do experimento.

Os motoristas que participaram dos testes realizados por esse trabalho são treinados para percorrer o trajeto de forma padronizada. Por isso, a forma de conduzir o veículo pelos motoristas não teve influência considerável nos resultados das medições realizadas.

Por fim, a execução do experimento dependeu de grande quantidade de recursos, principalmente da disponibilidade do ônibus, equipamentos de medição, além de motoristas qualificados e mão de obra especializada para operação dos equipamentos que, em conjunto, restringiram a flexibilidade da realização das medições principalmente quanto aos trajetos escolhidos e aos horários desejados.

\subsubsection{Experimento Fase 2 - Antena posicionada no teto do veículo}

A segunda fase do experimento foi realizada em apenas um dia (13/02/2013) devido à restrita disponibilidade do veículo, que se envolveu em uma colisão e teve de ser retirado de circulação para manutenção, impossibilitando a continuação dos testes.

O objetivo da segunda fase foi verificar se a aquisição de dados apenas por equipamento receptor GPS (através da VGPS) poderia ser utilizada como uma forma mais simples e tão eficaz quanto adquirir dados diretamente da ECU (VCAN) de um veículo, que exige equipamentos e conhecimento mais específicos para este 
fim (por exemplo, a conexão e sincronização dos módulos eletrônicos veiculares com os dispositivos VBOX), desde que garantida a alta qualidade de sinal para o receptor GPS.

Durante a segunda fase do experimento foram adquiridos 384 minutos ( 6 horas e 24 minutos, com pausas para descanso) de dados de deslocamento do ônibus em teste, com apenas um motorista, iniciando os testes às $17 \mathrm{~h} 03$ e finalizando às $00 h 44$.

A Tabela 4 mostra o resumo dos dados adquiridos durante as medições da fase 2 do experimento e os valores de velocidade média e desvio padrão para cada uma das fontes, GPS e CAN, com resultados muito semelhantes, mesmo sem filtrar picos de velocidade registrados indevidamente pelo GPS. A correlação entre as medidas de velocidade VGPS e VCAN foi calculada em 98,7\%.

Tabela 4 - Resumo de dados adquiridos durante a fase 2 do experimento

\begin{tabular}{cccccr}
\hline Arquivo & Data & $\begin{array}{c}\text { Hora } \\
\text { (início) }\end{array}$ & $\begin{array}{c}\text { VGPS } \\
\mathrm{km} / \mathrm{h}\end{array}$ & $\begin{array}{c}\text { VCAN } \\
\mathrm{km} / \mathrm{h}\end{array}$ & $\begin{array}{r}\text { Tempo total } \\
\text { minutos }\end{array}$ \\
\hline total_VBOX_005 & $13 / 02 / 2013$ & $17: 03$ & $12,3 \pm 15,6$ & $12,4 \pm 15,5$ & 80 \\
total_VBOX_006 & $13 / 02 / 2013$ & $18: 35$ & $10,1 \pm 12,0$ & $10,1 \pm 11,8$ & 241 \\
total_VBOX_007 & $13 / 02 / 2013$ & $23: 41$ & $19,9 \pm 15,1$ & $19,9 \pm 15,2$ & 63 \\
\hline \multicolumn{2}{c}{ Total } & & $\mathbf{1 2 , 1 \pm 1 3 , 8}$ & $\mathbf{1 2 , 1 \pm \mathbf { 1 3 , 7 }}$ & $\mathbf{3 8 4}$
\end{tabular}

Em seguida foram calculadas as divergências para as medidas de velocidade VGPS com base na velocidade VCAN. De forma resumida, em aproximadamente $88 \%$ das observações, as velocidades têm o mesmo valor em ambas as fontes utilizadas, o que pode ser visualizado na Figura 19. 


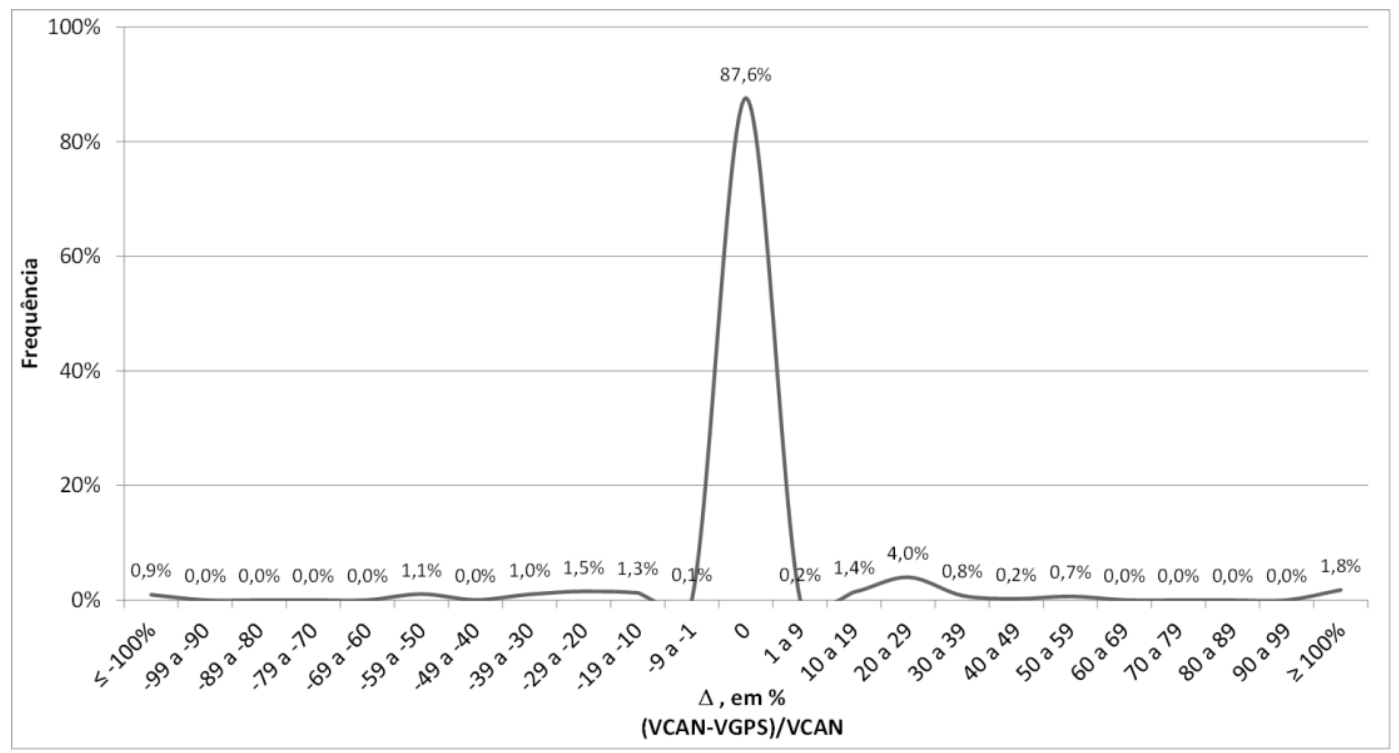

Figura 19 - Desvio entre medidas de velocidade VCAN e VGPS

Desta forma, verifica-se que se a aquisição de dados for feita de forma controlada e com poucas falhas de sinal nas aquisições de velocidade do receptor GPS, a variação entre os valores de VGPS e VCAN deverá ser pequena.

Além das comparações de velocidade, para as medições realizadas na fase 2 foram calculados os valores de VSP e em seguida determinada a sua distribuição, resultando no gráfico apresentado na Figura 20.

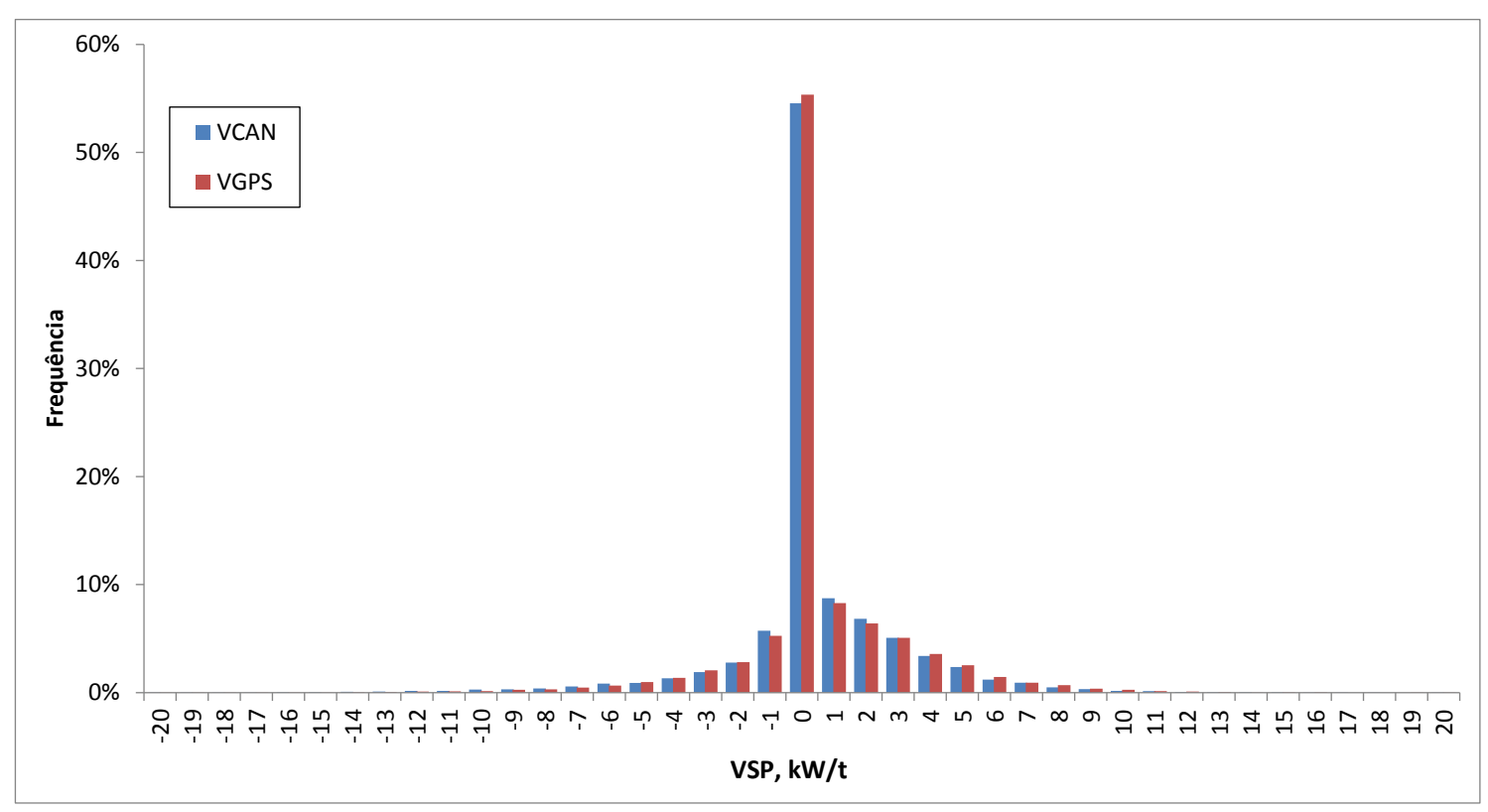

Figura 20 - Distribuição de VSP para as fontes de velocidade VCAN e VGPS. 
De acordo com a pequena diferença entre as medidas de velocidade, as distribuições de VSP calculadas a partir das diferentes fontes de velocidade VGPS e VCAN resultaram em valores muito semelhantes, conforme mostram a Figura 20 e a Tabela 5.

Tabela 5 - Distribuições de VSP para velocidades adquiridas pelas fontes CAN e GPS

\begin{tabular}{ccc}
\hline Faixas de VSP & \multicolumn{2}{c}{ Distribuição } \\
kW/t & VCAN & VGPS \\
\hline-20 a -11 & $0,6 \%$ & $0,4 \%$ \\
-10 a -1 & $15,0 \%$ & $14,3 \%$ \\
0 & $54,6 \%$ & $55,4 \%$ \\
1 a 10 & $29,5 \%$ & $29,5 \%$ \\
11 a 20 & $0,3 \%$ & $0,4 \%$ \\
\hline
\end{tabular}

Sendo assim, verifica-se que experimentos que realizam medidas de velocidade registradas pelos mesmos equipamentos utilizados neste trabalho, podem ser executados tendo apenas a VGPS como fonte, podendo levar a obtenção de resultados semelhantes em termos de distribuição VSP quando comparados àqueles experimentos que utilizam a VCAN como fonte de medida de velocidade. 


\section{ANÁLISE DE DADOS E CONSTRUÇÃO DE CICLOS DE CONDUÇÃO}

\subsection{ANÁLISE DO TRAJETO COMPLETO E CICLO DE CONDUÇÃO 01}

Concluída a fase experimental do trabalho, com o término dos testes com ônibus, passou-se para a etapa de preparação e análise dos dados obtidos empiricamente. Os dados foram compilados e tratados através de uma rotina específica em software de planilha eletrônica, para que pudessem ser verificados principalmente quanto à sua validade, se todas as informações coletadas (principalmente dados de posicionamento e velocidade) possuíam valores dentro das faixas esperadas.

A primeira etapa da análise agrupa todos os dados obtidos em uma única planilha eletrônica, onde são calculadas as acelerações, as inclinações das vias e os valores de VSP a cada segundo e a quebra das microviagens. Para o total de dados válidos obtidos, representando o percurso de testes completo, foi calculada a distribuição dos valores de VSP no tempo e, em seguida, fazendo uso da metodologia apresentada por Lai et al.(2012), foi proposto um ciclo de condução geral para este mesmo trajeto completo.

Para o cálculo do VSP, os valores das variáveis coeficiente de resistência à rolagem $(\psi)$ e o termo do coeficiente de arrasto $(\zeta)$ - dependente da densidade do ar, coeficiente de arrasto, área frontal e massa do veículo - foram baseados nos valores do experimento realizado por Zhai et al.(2008), também com ônibus urbanos, mostrados na Tabela 6.

Os valores de velocidade foram medidos com os equipamentos descritos anteriormente no item 3.1 e a aceleração foi calculada com base na variação de velocidade registrada; foi também obtida a inclinação da via, calculada pela variação da altitude e deslocamento do veículo.

Por não contar com equipamento específico para este fim, a inclinação das vias percorridas foi calculada a partir da variação de altitude registrada pelo receptor 
GPS, considerando os cinco segundos anteriores, sendo por fim convertida em radianos para aplicação na equação do VSP.

Tabela 6 - Valores utilizados no cálculo de VSP - baseados em Zhai et al. (2008).

\begin{tabular}{llr}
\hline \multicolumn{1}{c}{ Variável } & & \multicolumn{1}{c}{ Valor } \\
\hline Velocidade (medida) & $\mathrm{em} \mathrm{m} / \mathrm{s}$ \\
Aceleração (calculada) & $\mathrm{a}$ & $\mathrm{em} \mathrm{m} / \mathrm{s}^{2}$ \\
Gravidade & $\mathrm{g}$ & $9,81 \mathrm{~m} / \mathrm{s}^{2}$ \\
Inclinação da via (calculada) & $\phi$ & em radianos \\
Coeficiente de resistência à rolagem & $\psi$ & 0,092 \\
Termo do Coeficiente de arrasto & $\zeta$ & $0,00021 \mathrm{~m}^{-1}$ \\
\hline
\end{tabular}

Após processados, o total de dados válidos na primeira fase do experimento, de aproximadamente 294 horas, resultou em uma soma de 10308 microviagens com duração média de 103 segundos (para Lai et al., 2012, duração média de 85 segundos), velocidade média de $15,3 \mathrm{~km} / \mathrm{h}$ e com a distribuição de VSP conforme mostra a Figura 21:

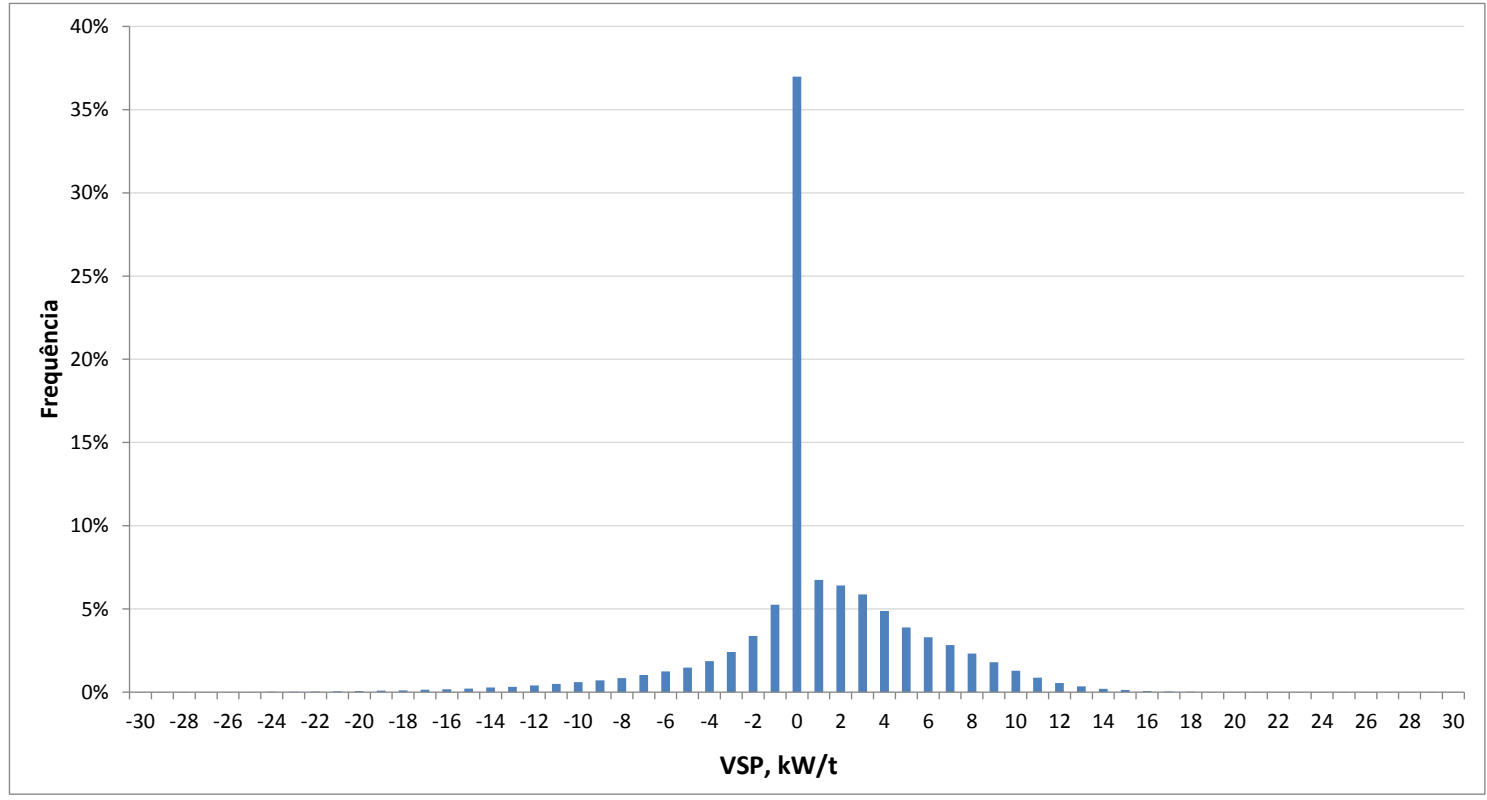

Figura 21 - Distribuição de VSP para o total de dados adquiridos na fase 1.

O cálculo dos valores de VSP para a amostra total de dados é importante para poder compará-los com os valores encontrados na análise isolada dos diversos tipos de vias individualmente, que serão apresentados posteriormente. Para a amostra total de dados a faixa de valores possíveis de VSP foi escolhida de -30 a $30 \mathrm{~kW} / \mathrm{t}$ por 
representar 99,7\% das microviagens adquiridas (de -20 a 20kW/t representa 99,5\%). Para as distribuições de VSP dos trechos menores (segmentos da amostra total, selecionados a partir do trajeto completo, para representar diferentes condições de operação, no item 4.3), essa faixa será reduzida para -20 a $20 \mathrm{kw} / \mathrm{t}$, que em média representa 99,8\% das microviagens, já que esses trechos não apresentam a mesma variação dos dados de distribuição de VSP como o trajeto completo. A partir deste ponto as faixas de VSP serão mostradas nos gráficos e tabelas de forma adimensional (unidade kW/t) para simplificar a apresentação.

A distribuição de VSP para a amostra total de dados da primeira fase resultou em um grande percentual de valores iguais a zero, 37\%, o que representa o momento em que o veículo está com velocidades e acelerações muito baixas (aproximadamente iguais a zero) ou não está em movimento, o que de certa forma é esperado para a operação de um ônibus urbano.

A Tabela 7 mostra os valores utilizados na construção do gráfico da Figura 21, porém em grupos de 10 classes de VSP, com exceção do zero, mostrado isoladamente, para possibilitar uma análise mais precisa dos resultados de VSP.

Tabela 7 - Distribuição VSP para a amostra total de dados da fase 1.

\begin{tabular}{cc}
\hline Faixas VSP & Distribuição \\
\hline-30 a -21 & $0,2 \%$ \\
-20 a -11 & $2,3 \%$ \\
-10 a -1 & $18,9 \%$ \\
0 & $37,0 \%$ \\
1 a 10 & $39,3 \%$ \\
11 a 20 & $2,3 \%$ \\
21 a 30 & $0,0 \%$ \\
\hline
\end{tabular}

Tanto na Figura 21 quanto na Tabela 7 é possível notar a tendência maior de aceleração (VSP>0) do que de desaceleração $(\mathrm{VSP}<0)$; o veículo permanece $21,4 \%$ do tempo desacelerando e $41,6 \%$ do tempo acelerando. Esta diferença, como será mostrado posteriormente, impacta diretamente nas emissões de poluentes, já que valores de VSP positivos resultarão em maiores emissões de poluentes e maior 
consumo de combustível do que valores iguais ou menores que zero, como demonstrado por Jimenez-Palacios (1999) e ilustrados nas Figuras 8 e 9 do item 2.3.

Para a construção dos ciclos de condução foi utilizada a metodologia proposta por Lai et al. (2012), descrita no item 2.2.5, pois considera parâmetros relacionados a emissões através da utilização do VSP, onde cada microviagem tem seus valores de VSP comparados com a amostra total de microviagens para testar sua similaridade através do RMSE e assim são selecionadas para formar o ciclo de condução com a duração escolhida previamente, de 20 minutos neste estudo e usualmente encontrada na literatura (SAE, 2002).

Além disso, essa metodologia é aplicada em um estudo realizado com objetivos e em condições muito semelhantes aos propostos no presente trabalho, que é a construção de ciclos de condução para ônibus urbanos focada nas emissões de poluentes.

De forma resumida, a sequência utilizada para a seleção das microviagens para construção dos ciclos pode ser observada na Figura 22, baseada na proposta de Lai et al. (2012). 


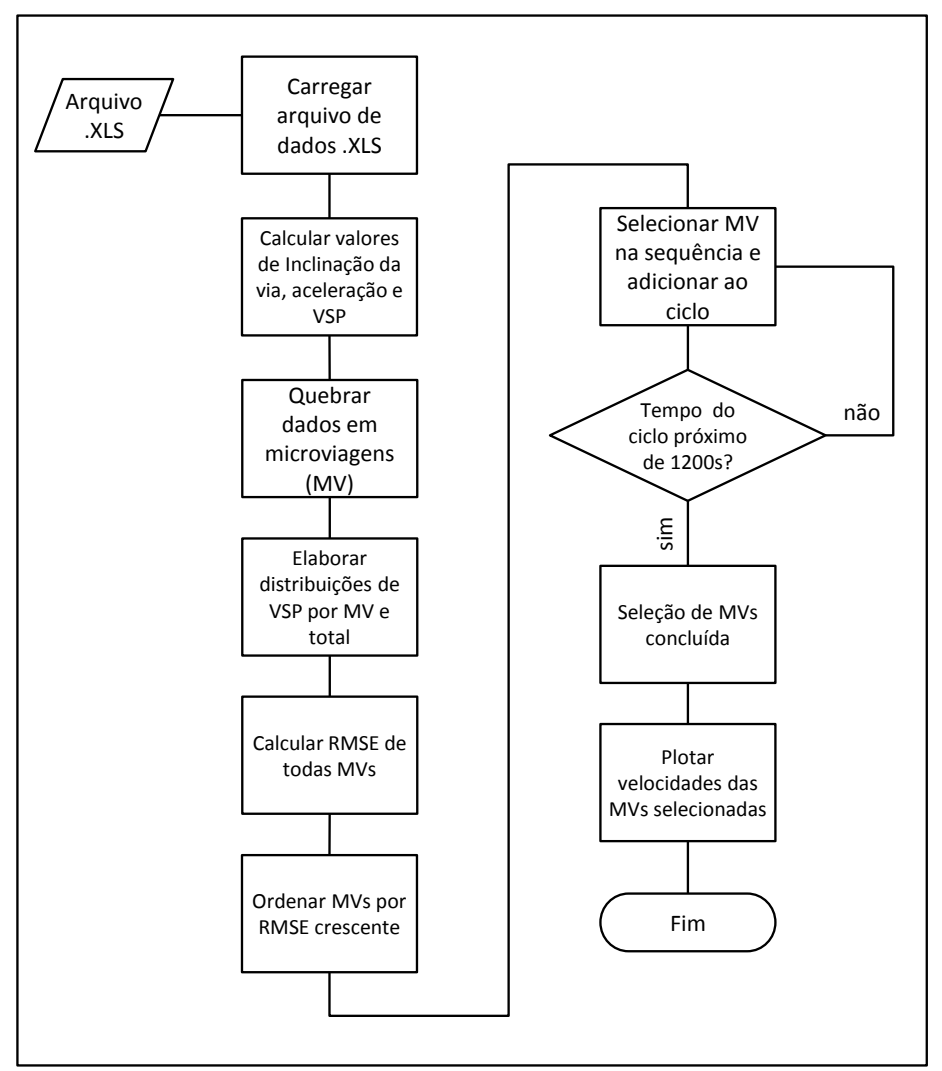

Figura 22 - Fluxograma para seleção de microviagens segundo Lai et al (2012).

O tempo total de aproximadamente 20 minutos (duração usual de ciclos de condução na literatura, Dai et al., 2008) foi escolhido para a construção do ciclo de condução do experimento. Desta forma, agrupando todas as microviagens por ordem crescente de RMSE e usando somente esse critério, elaborou-se o ciclo de condução para o conjunto total de dados do trajeto completo, que pode ser visto na Figura 23.

O ciclo de condução é formado por microviagens inteiras com sua duração mais próxima possível dos 20 minutos inicialmente estipulados. Se ao adicionar uma nova microviagem ao ciclo esse tempo for superado, é feita uma avaliação para verificar qual condição resulta em uma duração mais próxima da meta, com ou sem esta última microviagem. 


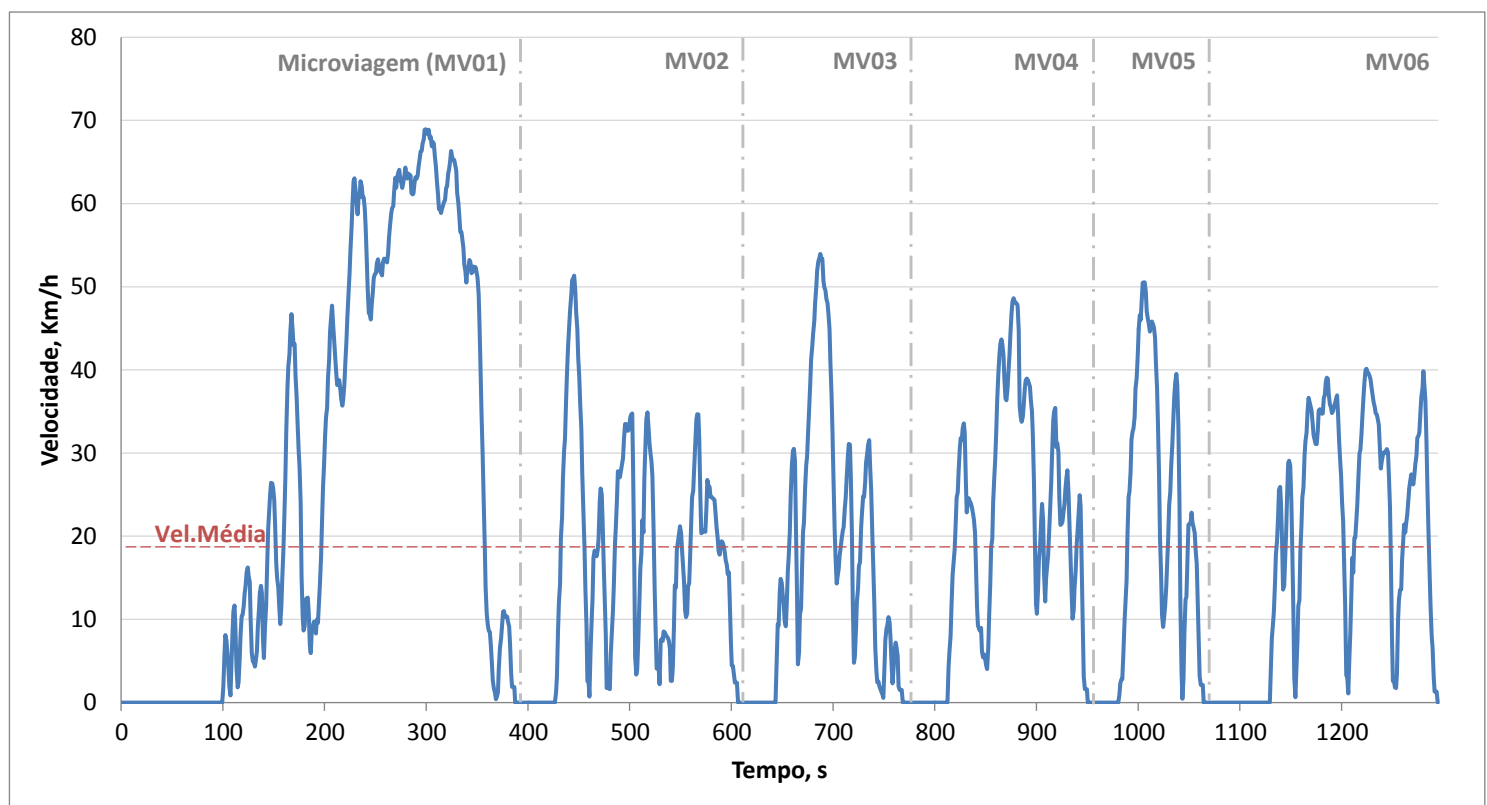

Figura 23 - Ciclo de condução do trajeto completo na fase 1 (Ciclo 01) - considerando somente RMSE das microviagens.

A partir do ciclo de condução construído na Figura 24 (ciclo 01), verificou-se que com auxílio dos valores de RMSE foram selecionadas microviagens com percentual de tempo parado muito próximos da média global, mas com duração maior do que a média, de aproximadamente $24,7 \%$ e 216 segundos respectivamente, sendo que os valores médios da primeira fase são de 24,6\% (média ponderada) e 103 segundos.

A Tabela 8 mostra para ciclo 01 o resumo das características das microviagens selecionadas. A coluna "sequência" mostra em qual posição a microviagem foi classificada por valores de RMSE, em relação a toda a amostra de microviagens obtidas durante o experimento.

Tabela 8 - Resumo das microviagens utilizadas na construção do ciclo 01.

\begin{tabular}{|c|c|c|c|c|c|c|}
\hline \multirow{2}{*}{ Sequência } & \multirow{2}{*}{ Arquivo } & \multirow{2}{*}{$\begin{array}{l}\text { Vel. Média } \\
\mathrm{km} / \mathrm{h}\end{array}$} & \multirow{2}{*}{$\begin{array}{c}\text { Duraçãa MV } \\
s\end{array}$} & \multicolumn{2}{|c|}{ Tempo parado } & \multirow{2}{*}{ RMSE } \\
\hline & & & & $\mathrm{s}$ & $\%$ & \\
\hline 1 & VBOX_343_MV_54 & 27,1 & 388 & 101 & $26,0 \%$ & 0,0051 \\
\hline 2 & VBOX_472_MV_33 & 16,3 & 219 & 40 & $18,3 \%$ & 0,0056 \\
\hline 3 & VBOX_291_MV_34 & 16,4 & 162 & 38 & $23,5 \%$ & 0,0059 \\
\hline 4 & VBOX_502_MV_123 & 18,6 & 182 & 45 & $24,7 \%$ & 0,0061 \\
\hline 5 & VBOX_396_MV_27 & 18,4 & 114 & 31 & $27,2 \%$ & 0,0062 \\
\hline \multirow[t]{4}{*}{6} & VBOX_350_MV_34 & 17,5 & 230 & 66 & $28,7 \%$ & 0,0063 \\
\hline & Média & 19,1 & 215,8 & 53,5 & & \\
\hline & Desvio Padrão & 4,1 & 94,1 & 26,1 & & \\
\hline & Soma & & 1295 & 321 & $24,8 \%$ & \\
\hline
\end{tabular}


Como foram selecionadas microviagens com duração média aproximada de 216 segundos, o ciclo 01 foi formado por seis microviagens com tempo total pouco acima da meta estimada inicialmente (20 minutos), totalizando 1295 segundos (21 minutos e 35 segundos), pois as microviagens foram utilizadas integralmente (sem interrupções) na composição do ciclo de condução.

O gráfico da Figura 24 apresenta as distribuições de VSP para o ciclo 01 e para a amostra total de dados (Total), onde é possível verificar a grande semelhança entre os valores resultantes da seleção das microviagens através do método proposto por Lai et al. (2012). A correlação entre ambas as distribuições de VSP é de 99,87\%.

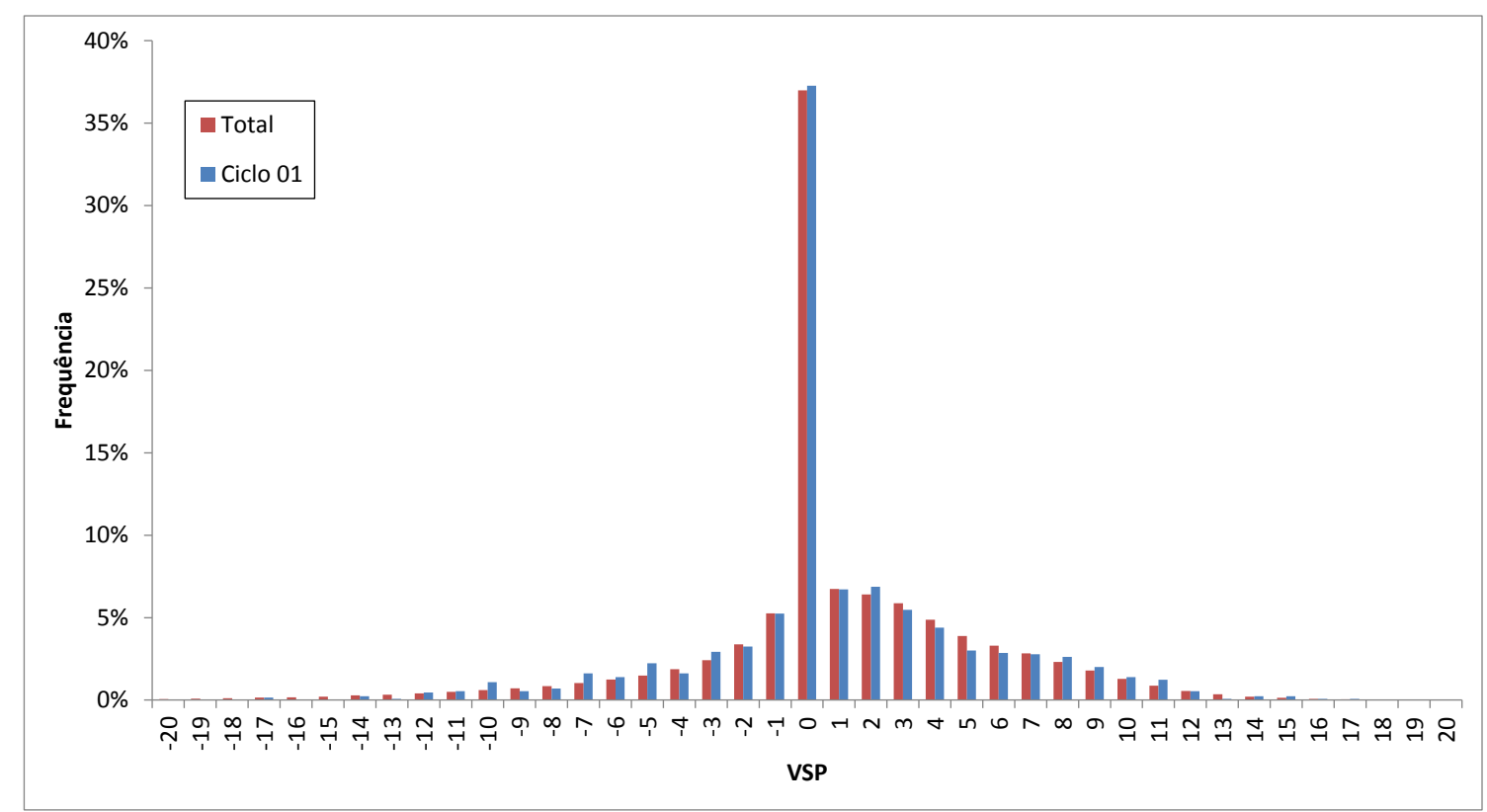

Figura 24 - Histograma da distribuição de VSP para o ciclo 01 e a amostra total de dados.

A partir da construção do primeiro ciclo de condução, foi desenvolvido o gráfico da Figura 25, que ordena todas as microviagens obtidas por ordem crescente de RMSE e mostra a proporção de tempo parado correspondente à cada microviagem. Em geral, as microviagens com percentual de tempo parado mais próximos à média (aprox. 28\%) tiveram os menores valores de RMSE. 


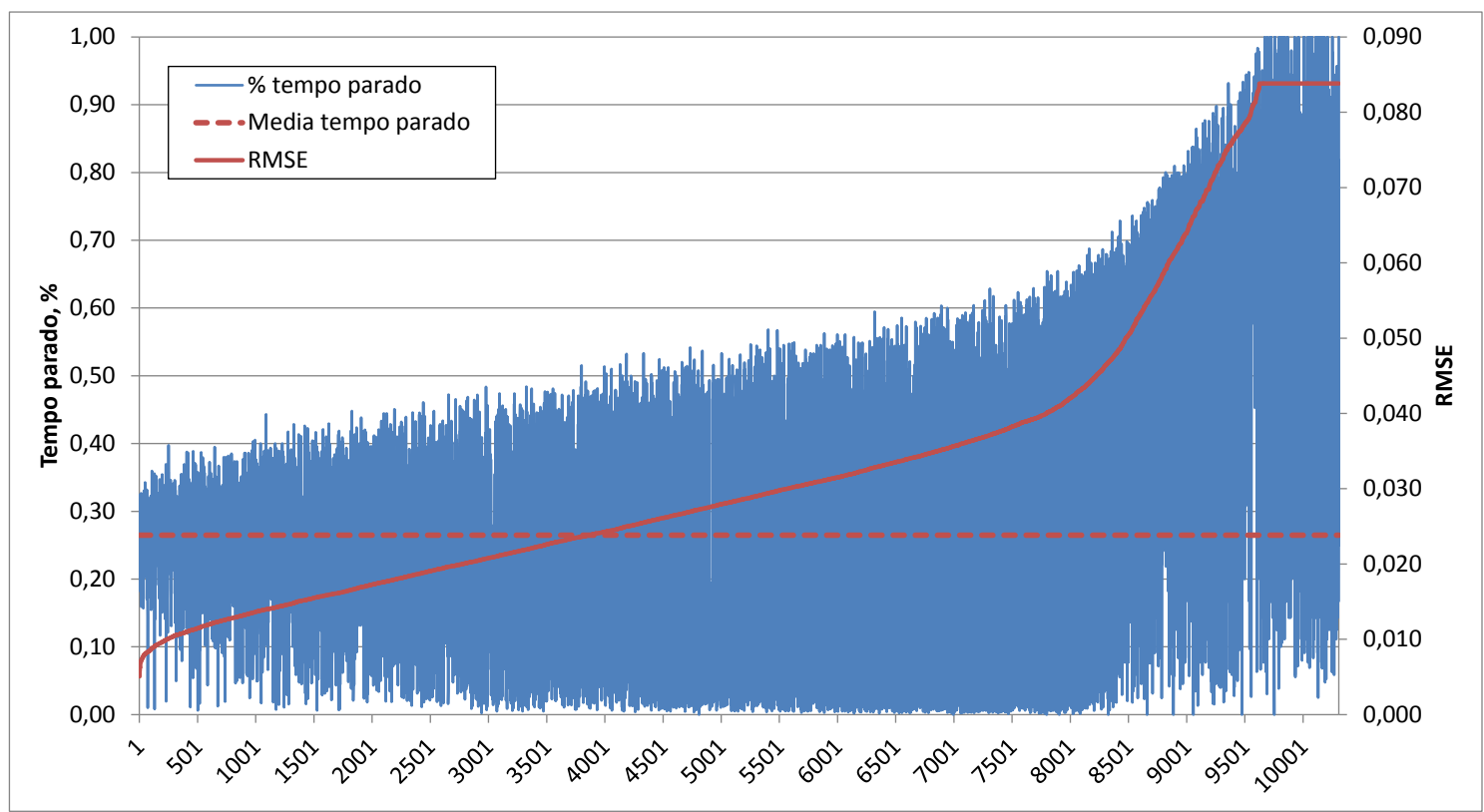

Figura 25 - Comparação de tempo parado x duração das microviagens classificadas em ordem crescente de RMSE - fase 1.

Desta forma, o comparativo apresentado nas Figuras 24 e 25 reforça que a aplicação do método de Lai et al. (2012) neste trabalho é capaz de selecionar as microviagens mais semelhantes à amostra que se tem como referência (em termos de distribuição de VSP).

\subsection{CONSTRUÇÃO E ANÁLISE DO CICLO DE CONDUÇÃO 02}

A metodologia proposta por Lai et al. (2012) foi combinada com a distribuição do percentual de tempo parado observado na amostra total, com o intuito de aumentar a semelhança das microviagens escolhidas para a construção do ciclo para este conjunto de dados.

O gráfico da Figura 26 mostra para o conjunto total de dados da fase 1 a distribuição de percentual de tempo parado medido por microviagem. Ou seja, neste gráfico está sendo mostrado o total de microviagens existentes para as faixas de percentual de tempo parado escolhidas: [0;25\%], ]25\%;50\%], ]50\%;75\%] e ]75\%;100\%]. 


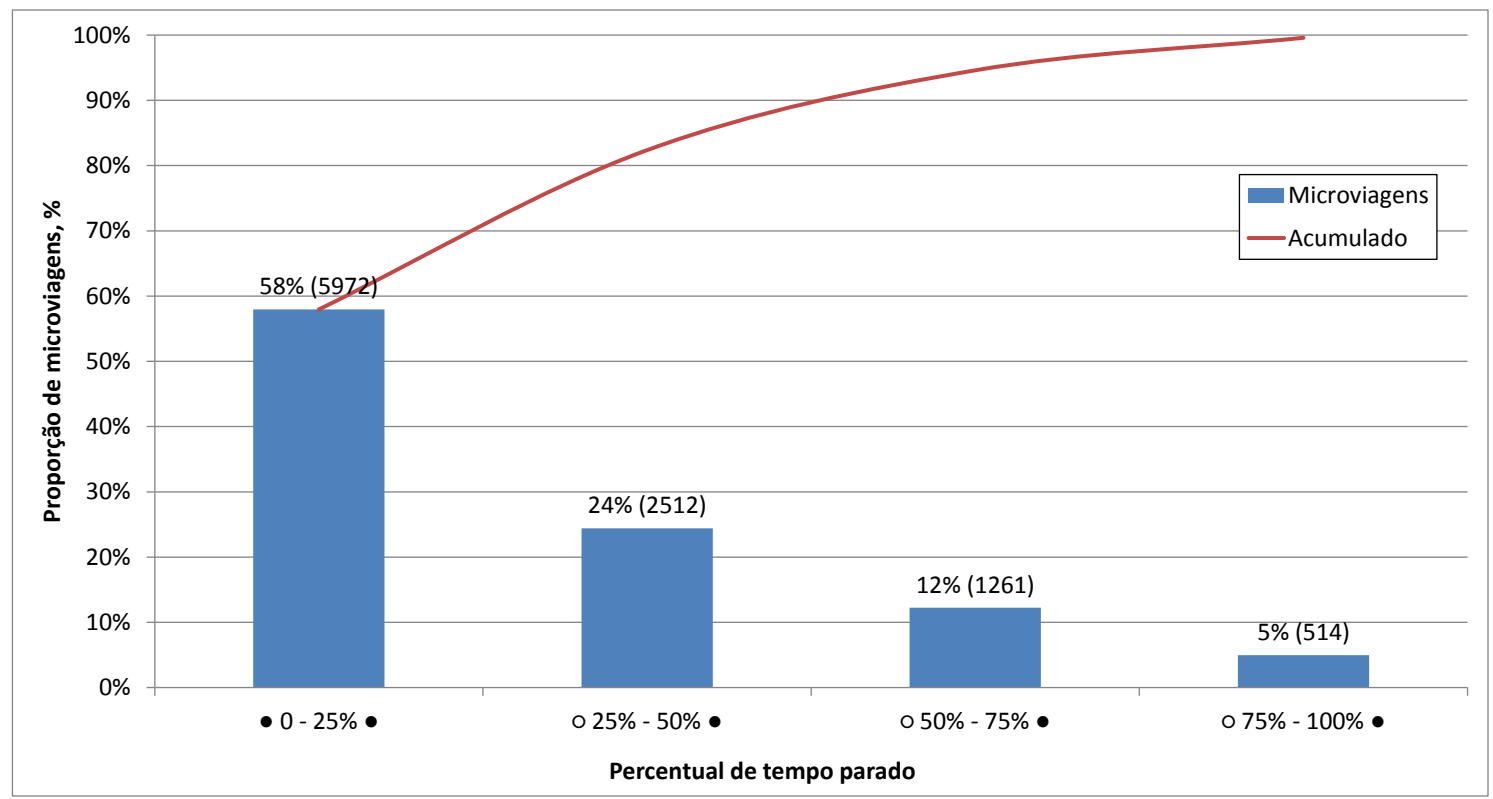

Figura 26 - Faixas de percentual de tempo parado por microviagem - Amostra de dados da fase 1.

Desta forma, propõe-se adicionar ao método de seleção um critério que analisa e considera também a composição das microviagens com relação ao tempo parado, a partir da distribuição de tempo parado apresentada na Figura 26, buscando construir um ciclo de condução mais representativo da amostra total de dados.

Além disso, para o desenvolvimento do segundo ciclo de condução foi incluída uma restrição para a duração máxima das microviagens selecionadas, que foi limitada a no máximo $20 \%$ da duração pretendida para o ciclo final de 20 minutos (portanto, 240 segundos), e assim permitir maior quantidade de microviagens na formação do ciclo.

Para selecionar as microviagens para a composição deste ciclo 02 , calculou-se 0 valor de RMSE para distribuição de VSP para cada microviagem, ordenando esse resultado de forma crescente. Em seguida foram procuradas microviagens com a duração máxima definida de 240 segundos e que tivessem distribuição de tempo parado dentro das faixas de percentual de tempo parado estabelecidas, somando suas durações até que atingissem o valor próximo à distribuição de tempo parado da amostra total. O algoritmo básico desta proposta de seleção de microviagens está mostrado na Figura 27. 


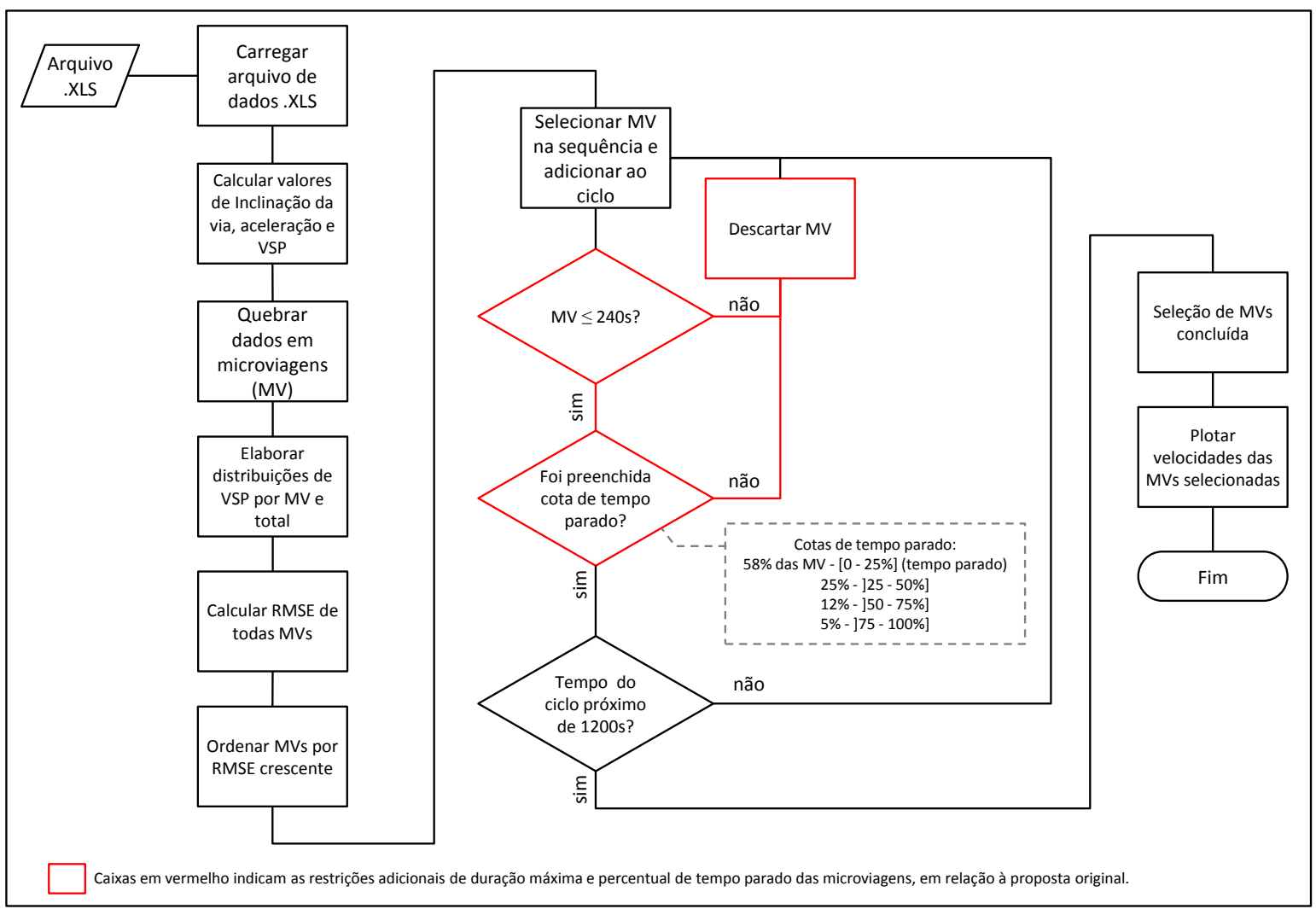

Figura 27 - Fluxograma para seleção de microviagens considerando duração máxima 240s e proporção de tempo parado pré-definindo.

A partir das premissas descritas anteriormente, foi elaborado o segundo ciclo de condução da amostra total de dados (ciclo 02), mostrado na Figura 28.

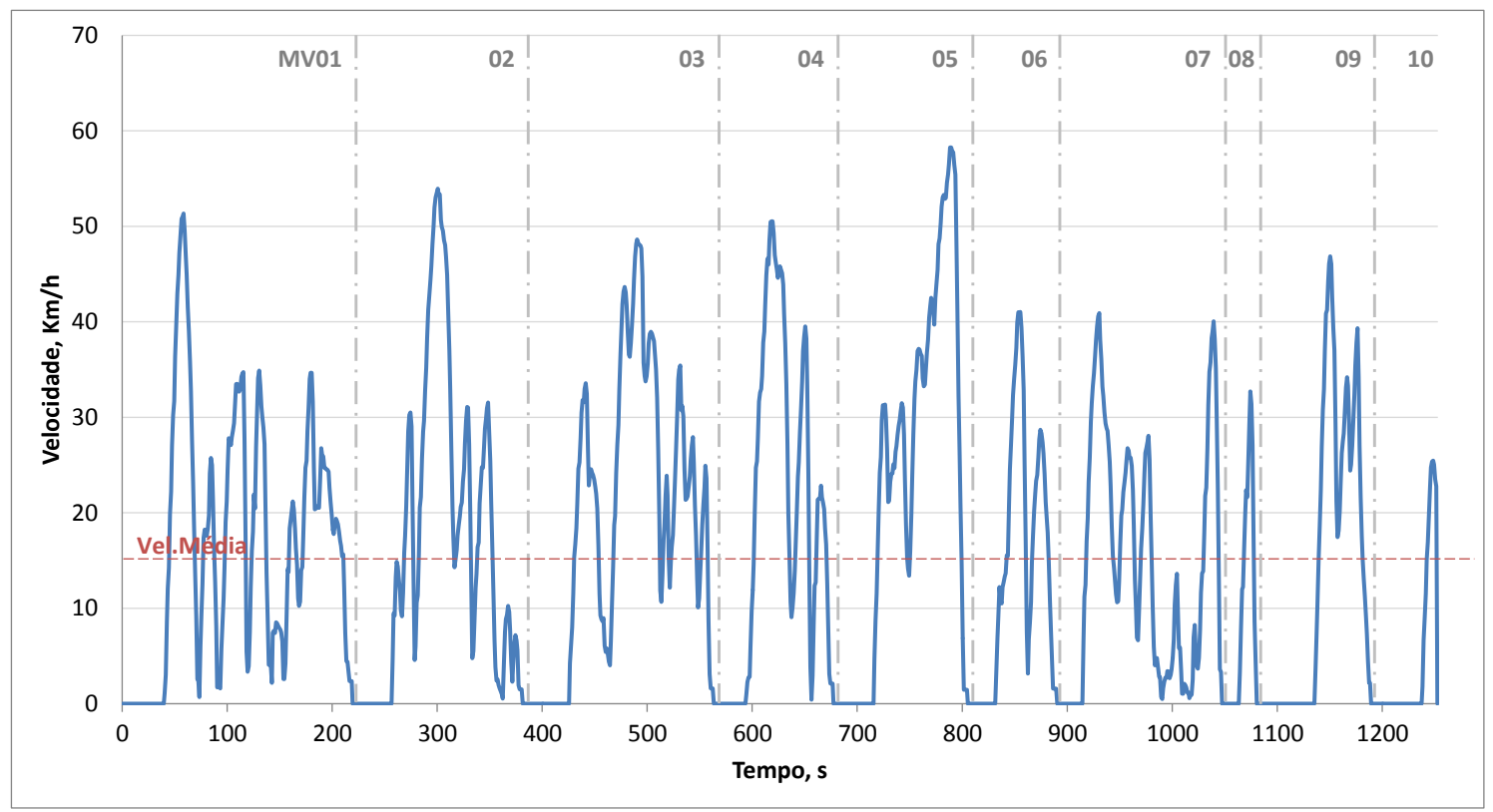

Figura 28 - Ciclo 02 formado por microviagens selecionadas pelo VSP e percentual de tempo parado - ordenadas por RMSE crescente. 
O ciclo 02 foi composto por 10 microviagens com velocidade média $14,5 \mathrm{~km} / \mathrm{h}$, duração total de 1251 segundos e distribuição de tempo parado muito semelhante ao apresentado na Figura 26, resumido na coluna distribuição amostra total, conforme mostrado na Tabela 9.

Tabela 9 - Distribuição de tempo parado das microviagens do ciclo 02.

\begin{tabular}{lrr}
\hline $\begin{array}{c}\text { Faixas de percentual de } \\
\text { tempo parado }\end{array}$ & $\begin{array}{c}\text { Soma } \\
\text { duração } \\
\text { Microviagens } \\
\text { s }\end{array}$ & $\begin{array}{c}\text { Distribuição } \\
\text { ciclo 02 }\end{array}$ \\
\hline$\bullet 0-25 \% \bullet$ & 720 & $58 \%$ \\
$\circ 25 \%-50 \% \bullet$ & 327 & $26 \%$ \\
$\circ 50 \%-75 \% \bullet$ & 142 & $11 \%$ \\
$\circ 75 \%-100 \% \bullet$ & 62 & $5 \%$ \\
\hline & Total & 1251
\end{tabular}

Distribuição

Amostra

Total

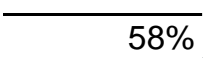

$58 \%$

$25 \%$

$12 \%$

$5 \%$

As características das microviagens selecionadas, bem como a ordem na qual elas estão apresentadas no ciclo são mostradas na Tabela 10. 
Tabela 10 - Características das microviagens que compõe o ciclo 02.

\begin{tabular}{|c|c|c|c|c|c|c|}
\hline \multirow{2}{*}{ Sequência } & \multirow{2}{*}{ Arquivo } & \multirow{2}{*}{$\begin{array}{l}\text { Vel. Média } \\
\text { km/h }\end{array}$} & \multirow{2}{*}{$\begin{array}{c}\text { Duração } \\
\text { microviagem } \\
\mathrm{s}\end{array}$} & \multicolumn{2}{|c|}{ Tempo parado } & \multirow{2}{*}{ RMSE } \\
\hline & & & & $\mathrm{s}$ & $\%$ & \\
\hline 2 & VBOX_472MV_33 & 16,3 & 219 & 40 & $18,3 \%$ & 0,0056 \\
\hline 3 & VBOX_291MV_34 & 16,4 & 162 & 38 & $23,5 \%$ & 0,0059 \\
\hline 4 & VBOX_502MV_123 & 18,6 & 182 & 45 & $24,7 \%$ & 0,0061 \\
\hline 5 & VBOX_396MV_27 & 18,4 & 114 & 31 & $27,2 \%$ & 0,0062 \\
\hline 8 & VBOX_333MV_50 & 22,5 & 128 & 39 & $30,5 \%$ & 0,0068 \\
\hline 13 & VBOX_336MV_160 & 13,4 & 85 & 27 & $31,8 \%$ & 0,0070 \\
\hline 17 & VBOX_275MV_37 & 14,0 & 157 & 25 & $15,9 \%$ & 0,0072 \\
\hline 3801 & VBOX_463MV_52 & 8,9 & 33 & 17 & $51,5 \%$ & 0,0236 \\
\hline 3997 & VBOX_374MV_25 & 12,6 & 109 & 56 & $51,4 \%$ & 0,0243 \\
\hline \multirow[t]{4}{*}{8785} & VBOX_300MV_203 & 4,0 & 62 & 48 & $77,4 \%$ & 0,0581 \\
\hline & Média & 14,5 & 125,1 & 36,6 & & \\
\hline & Desvio padrão & 5,3 & 56,7 & 11,7 & & \\
\hline & Soma & & 1251 & 366 & $29,3 \%$ & \\
\hline
\end{tabular}

Com as restrições adicionais definidas para a seleção (tempo parado por microviagem e duração máxima das microviagens), foram escolhidas mais microviagens para formar o ciclo 02 em comparação com o ciclo 01 .

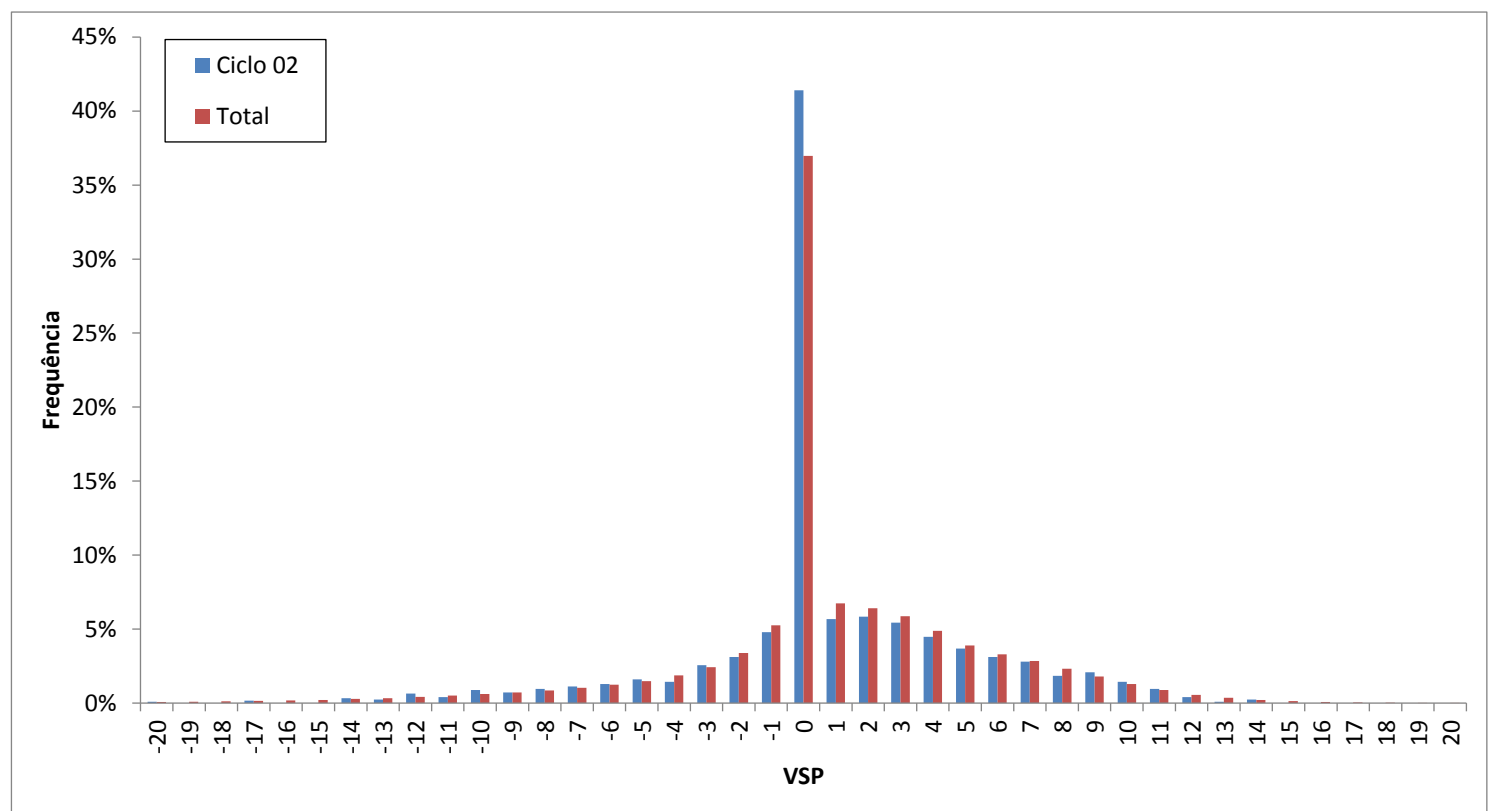

Figura 29 - Comparativo de distribuição de VSP para ciclo 02 e amostra total (Total).

Entretanto, as microviagens selecionadas não foram necessariamente as mais semelhantes em relação à amostra total de dados, o que pode ser notado na coluna "sequência" da Tabela 10 (classificação de acordo com valores de RMSE) e que 
também pode ser verificado na Figura 29, que compara a distribuição de VSP entre o total de dados e o ciclo 02 , notadamente menos semelhante à distribuição de VSP do ciclo 01 e total, mostrada na Figura 24.

A Tabela 11 mostra um comparativo das distribuições de VSP dos ciclos 01 e 02 , onde é possível verificar que a proposta de seleção de microviagens testada com o ciclo 02 mostra-se menos adequada, em termos de semelhança da distribuição de VSP, do que a metodologia apresentada por Lai et al. (2012).

Tabela 11 - Resumo comparativo entre as distribuições de VSP para os ciclos 01, 02 e o total de dados adquiridos.

\begin{tabular}{cccc}
\hline \multirow{2}{*}{ Faixas de VSP } & \multicolumn{3}{c}{ Distribuições } \\
& Ciclo 01 & Ciclo 02 & Total \\
\hline-20 a -11 & $1,5 \%$ & $1,8 \%$ & $2,3 \%$ \\
-10 a -1 & $20,6 \%$ & $18,5 \%$ & $18,9 \%$ \\
0 & $37,3 \%$ & $41,4 \%$ & $37,0 \%$ \\
1 a 10 & $38,1 \%$ & $36,4 \%$ & $39,3 \%$ \\
11 a 20 & $2,5 \%$ & $1,7 \%$ & $2,3 \%$ \\
\hline
\end{tabular}

\begin{tabular}{cc}
\hline \multicolumn{2}{c}{ Comparativos } \\
$\Delta_{\text {ciclo } 01 \text { - total }}$ & $\Delta_{\text {ciclo } 02 \text { - total }}$ \\
\hline$-0,9 \%$ & $-0,5 \%$ \\
$1,7 \%$ & $-0,4 \%$ \\
$0,3 \%$ & $4,4 \%$ \\
$-1,2 \%$ & $-2,9 \%$ \\
$0,2 \%$ & $-0,6 \%$ \\
\hline
\end{tabular}

Em resumo, os ciclos de condução 01 e 02 são diferentes entre si e também diferem da amostra total de dados, conforme mostrado na Tabela 12. O método de seleção das microviagens impactou diretamente em indicadores importantes como a velocidade e duração média e também nos valores de tempo parado e duração média das microviagens escolhidas, o que consequentemente influencia os resultados de estimativas de emissões de poluentes.

Tabela 12 - Resultados comparativos ciclos 01, 02 e Total.

\begin{tabular}{lccc}
\hline & Ciclo 01 & Ciclo 02 & Total \\
\hline Vel.Média, km/h & $19,2 \pm 4,1$ & $14,5 \pm 5,3$ & $15,3 \pm 9,6$ \\
Duração total do ciclo, s & 1295 & 1251 & - \\
Tempo parado no ciclo, s & 321 & 366 & - \\
Percentual de tempo parado, \% & $24,8 \%$ & $29,3 \%$ & $24,6 \%$ \\
Duração média das microviagens, s & 215,8 & 125,1 & 102,7 \\
№ de microviagens no ciclo & 6 & 10 & - \\
\hline
\end{tabular}


Apesar da maior diferença da velocidade média em relação à amostra total e do menor número de microviagens que compõem o ciclo 01, ao verificar a distribuição de velocidades (Figura 30(a)), este ciclo é mais semelhante ao total de observações nas velocidades baixas e intermediárias, que têm a maior frequência, enquanto o ciclo 02 é mais parecido nas altas velocidades. Já para a distribuição de acelerações ambos os ciclos são bastante semelhantes à amostra total de dados (Figura 30(b)).

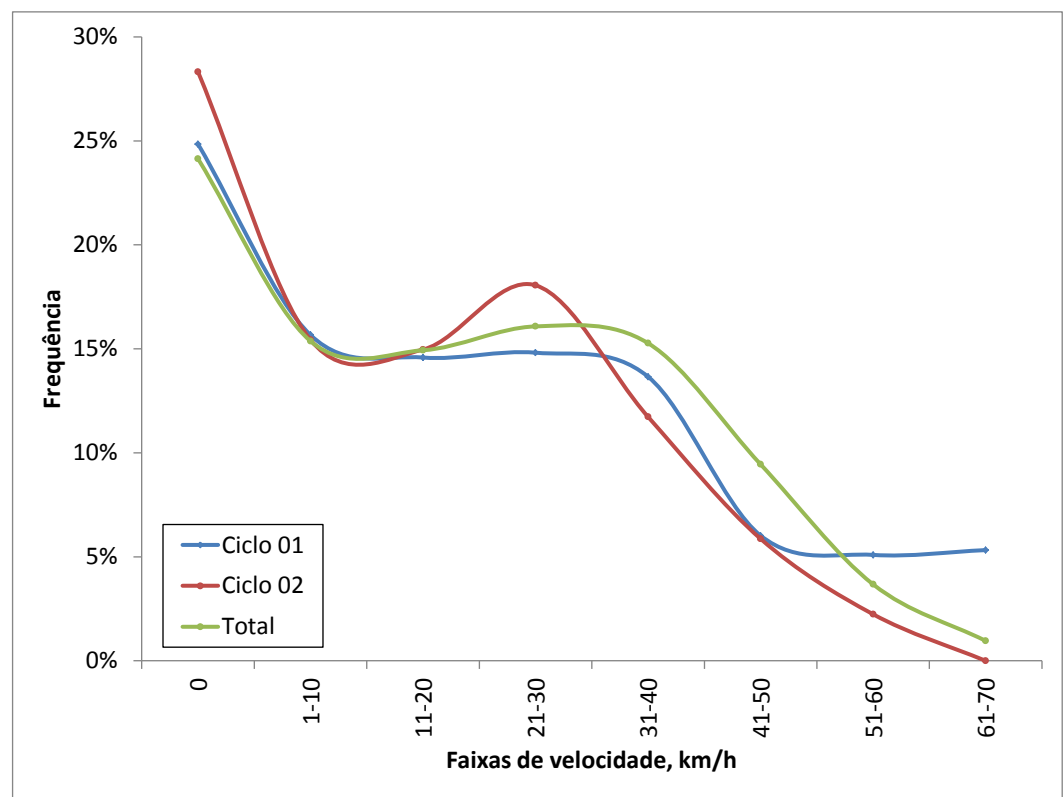

(a)

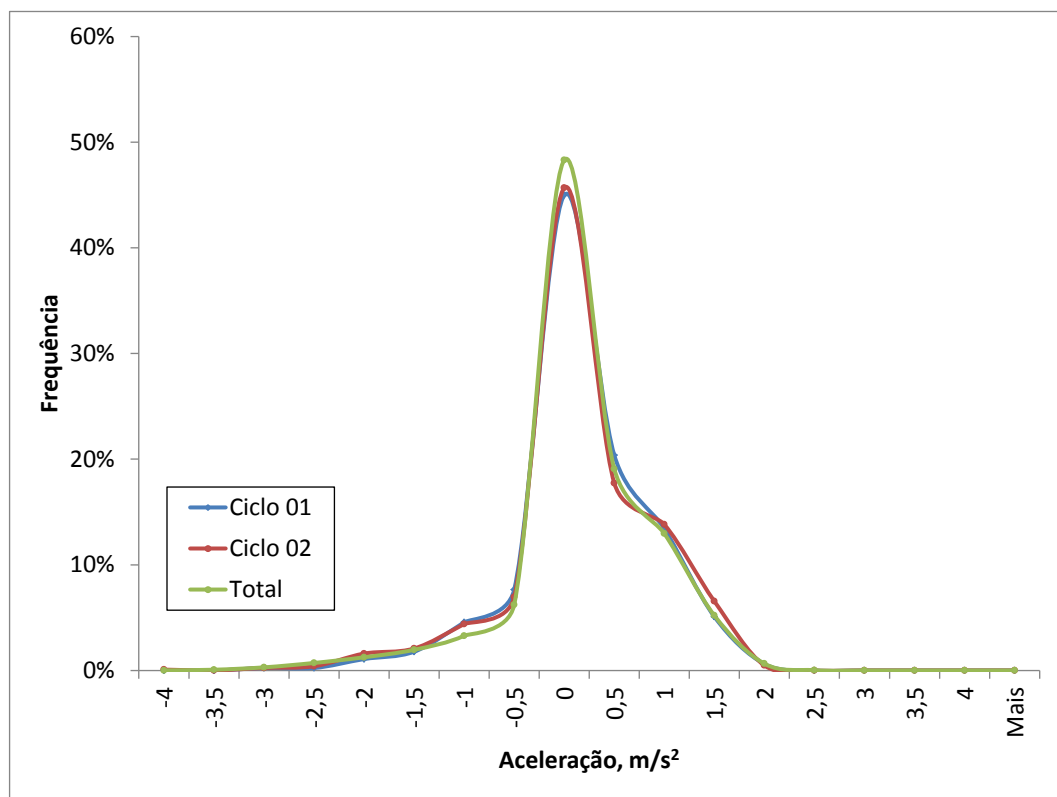

(b)

Figura 30 - Distribuição de velocidade (a) e aceleração (b) para os ciclos 01, 02 e amostra total. 
Além disso, o ciclo 01 consegue representar mais adequadamente a "compactação" do total de dados adquiridos em relação à distribuição de VSP conforme mostrado anteriormente.

Uma vez que a distribuição de VSP é uma das referências utilizadas para a aplicação de métodos de estimativa de emissões, valida-se que a metodologia utilizada para selecionar as microviagens proposta por Lai et al. (2012) consegue resultados semelhantes à amostra total de dados. Desta forma, para os trechos extraídos do trajeto completo de testes, que serão analisados no próximo capítulo, será aplicada esta metodologia. 


\subsection{ANÁLISE DE VSP E CONSTRUÇÃO DE CICLOS POR TRECHO}

Após a análise dos resultados e construção de ciclos de condução para a amostra total de dados do experimento, foram selecionados trechos (que podem ser uma única via ou sequência de vias) que pudessem representar condições de operação e características geométricas diversas. A Tabela 13 mostra um resumo das informações básicas dos trechos selecionados para o estudo.

Tabela 13 - Informações básicas das vias selecionadas para análise individual.

\begin{tabular}{|c|c|c|c|c|c|c|c|c|}
\hline \multirow[t]{2}{*}{ Trecho } & \multirow[t]{2}{*}{ Vias } & \multirow[t]{2}{*}{ Características } & \multirow{2}{*}{$\begin{array}{c}\text { Extensão } \\
\text { km }\end{array}$} & \multirow{2}{*}{$\begin{array}{l}\text { Velocidade } \\
\text { Máxima } \\
\text { Permitida } \\
\text { km/h }\end{array}$} & \multirow{2}{*}{$\begin{array}{c}\text { Velocidade } \\
\text { média } \\
\mathrm{km} / \mathrm{h}\end{array}$} & \multirow{2}{*}{$\begin{array}{c}\text { Duração } \\
\text { Média } \\
\text { Microviagem } \\
\text { s }\end{array}$} & \multicolumn{2}{|c|}{$\begin{array}{l}\text { Tempo médio } \\
\text { parado na } \\
\text { microviagem }\end{array}$} \\
\hline & & & & & & & $s$ & $\%$ \\
\hline A & $\begin{array}{l}\text { R. Antonio Doll de Morais / } \\
\text { Av.Conceição / Av. Engenheiro } \\
\text { Armando de Arruda Pereira (São } \\
\text { Paulo) }\end{array}$ & $\begin{array}{l}\text { Via de mão dupla com duas faixas } \\
\text { de tráfego compartilhado em cada } \\
\text { sentido separadas por corredor de } \\
\text { circulação exclusiva de ônibus } \\
\text { (veículo em testes não circulou pelo } \\
\text { corredor). }\end{array}$ & 4,9 & 60 & 16,1 & 80,4 & 12,6 & $15,7 \%$ \\
\hline B & $\begin{array}{l}\text { Av. Prestes Maia / Av. do Taboão - } \\
\text { (São Bernardo do Campo/Diadema) }\end{array}$ & $\begin{array}{l}\text { Via de mão dupla com duas faixas } \\
\text { de tráfego compartilhado em cada } \\
\text { sentido separadas por tachões } \\
\text { ("tartarugas"). }\end{array}$ & 5,0 & 60 & 13,3 & 84,0 & 21,5 & $25,6 \%$ \\
\hline C & Av. do Cursino (São Paulo) & $\begin{array}{l}\text { Via de mão dupla com uma a duas } \\
\text { faixas de tráfego compartilhado em } \\
\text { cada sentido separadas por faixa. }\end{array}$ & 6,8 & 60 & 15,6 & 87,7 & 15,8 & $18,0 \%$ \\
\hline D & $\begin{array}{l}\text { Av. José Cabalero / R. Cel. Alfredo } \\
\text { Flaquer / Av. Santos Dumont / R. } \\
\text { Giovanni Battista Pirelli / Av. João } \\
\text { Ramalho (Santo André) }\end{array}$ & $\begin{array}{l}\text { Via de mão dupla com três faixas } \\
\text { de tráfego compartilhado em cada } \\
\text { sentido separadas por faixa. }\end{array}$ & 7,4 & 60 & 18,7 & 98,8 & 20,1 & $20,3 \%$ \\
\hline $\mathbf{E}$ & $\begin{array}{l}\text { Av. Engenheiro Armando de Arruda } \\
\text { Pereira / Av. Dr. Hugo Beolchi / Av. } \\
\text { Jabaquara / R. Domingos de Morais } \\
\text { (São Paulo) }\end{array}$ & $\begin{array}{l}\text { Via de mão dupla com três a quatro } \\
\text { faixas de tráfego compartilhado em } \\
\text { cada sentido separadas por } \\
\text { canteiro central }\end{array}$ & 5,6 & 60 & 11,6 & 81,3 & 33,1 & $40,7 \%$ \\
\hline
\end{tabular}

Os trechos foram selecionados de forma que pudessem representar condições de operação diversas, com características geométricas distintas e com diferentes indicadores tais como extensão, velocidade média, tempo médio parado e duração média das microviagens.

O tráfego nas vias não foi medido ou avaliado diretamente, porém está sendo considerado indiretamente a partir dos indicadores citados e da avaliação dos trechos observados em períodos de pico (das 07 às 10h, pico da manhã - das 17 às $20 \mathrm{~h}$ pico da tarde) e fora de pico de trânsito (demais horários). Todos os trechos selecionados para análise detalhada foram percorridos pelo ônibus do experimento 
em ambas as condições de tráfego e seus percentuais podem ser verificados na Tabela 14.

Tabela 14 - Distribuição das observações segundo os horários de pico e fora de pico nos trechos percorridos durante o experimento.

\begin{tabular}{lcc}
\hline Trecho & Pico & Fora Pico \\
\hline A & $40,3 \%$ & $59,7 \%$ \\
B & $36,4 \%$ & $63,6 \%$ \\
C & $34,3 \%$ & $65,7 \%$ \\
D & $73,3 \%$ & $26,7 \%$ \\
E & $44,8 \%$ & $55,2 \%$ \\
\hline Total & $\mathbf{4 8 , 2} \%$ & $\mathbf{5 1 , 8 \%}$
\end{tabular}

Conforme justificado anteriormente (item 3.1), não foi possível percorrer corredores exclusivos com o ônibus de testes e, desta forma, as vias que possuem tais corredores foram selecionadas para análise a fim de verificar o impacto destes na circulação dos ônibus nas faixas compartilhadas com os demais veículos.

Para a análise dos trechos selecionados foram calculados os valores de VSP e sua distribuição e elaborados ciclos de condução para que estes trechos possam ser comparados e por fim terem os valores de emissões de poluentes estimados. 


\subsubsection{Trecho A - Rua Antonio Doll de Morais (Diadema), avenidas Conceição} (São Paulo) e Eng. Armando de Arruda Pereira

O trecho A foi composto a partir do percurso formado pelas vias rua Antônio Doll de Morais e avenidas Conceição e Engenheiro Armando de Arruda Pereira, sentido A-B da Figura 31, nos municípios de Diadema e São Paulo, totalizando 4,9km de extensão. Este trecho teve 30.215 segundos (aprox. 504 minutos, em 376 microviagens) de dados adquiridos durante o experimento.

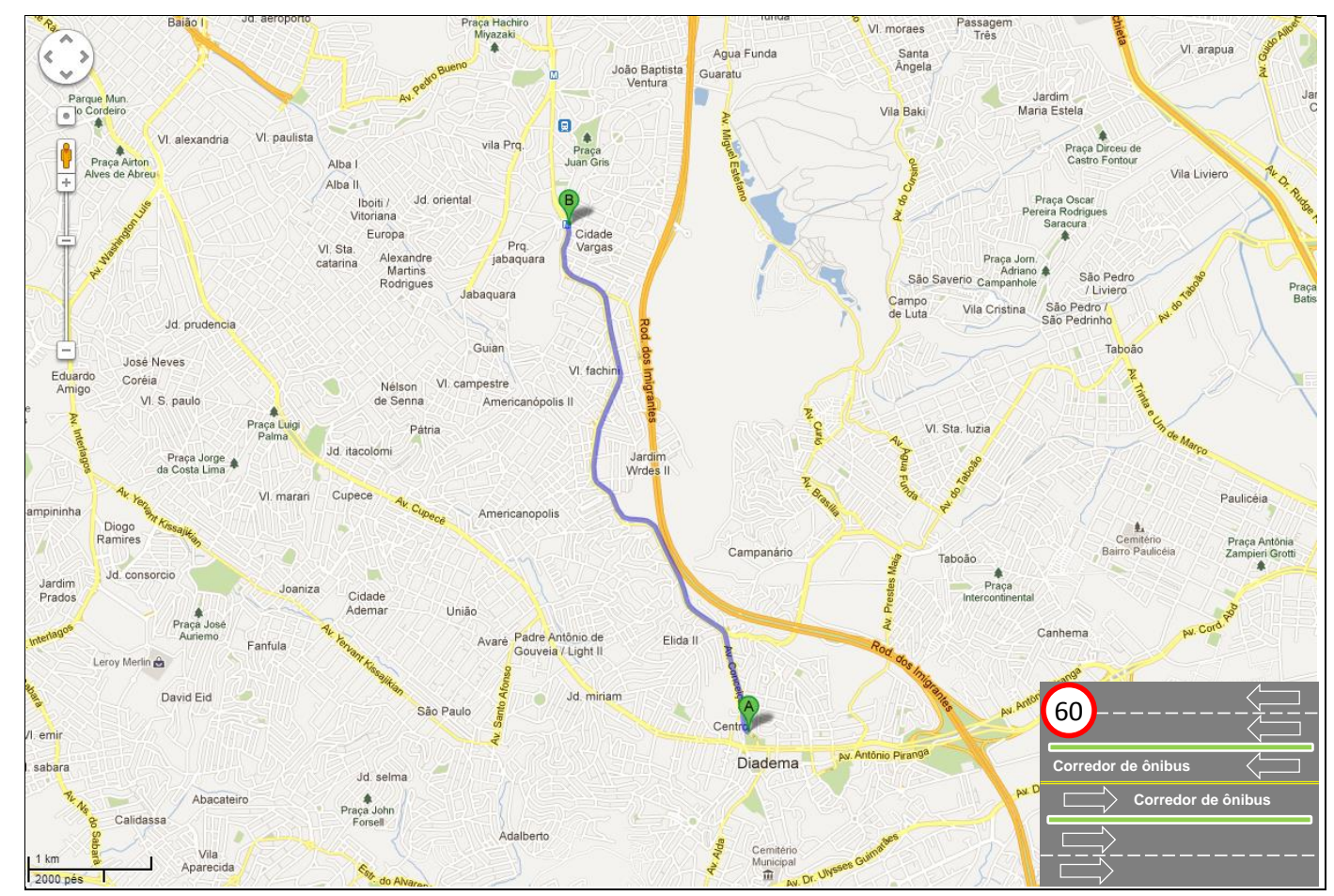

Figura 31 - Trecho A - R. Antonio Doll de Morais / Av.Conceição / Av. Engenheiro Armando de Arruda Pereira (Diadema / São Paulo) - Percorrida no sentido A-B.

A maior parte do trajeto é composta de vias de mão dupla com duas faixas de rolamento em cada sentido com separação por corredor de circulação exclusiva de ônibus, conforme detalhe no canto direito inferior da Figura 31 e Figura 32 a seguir. 


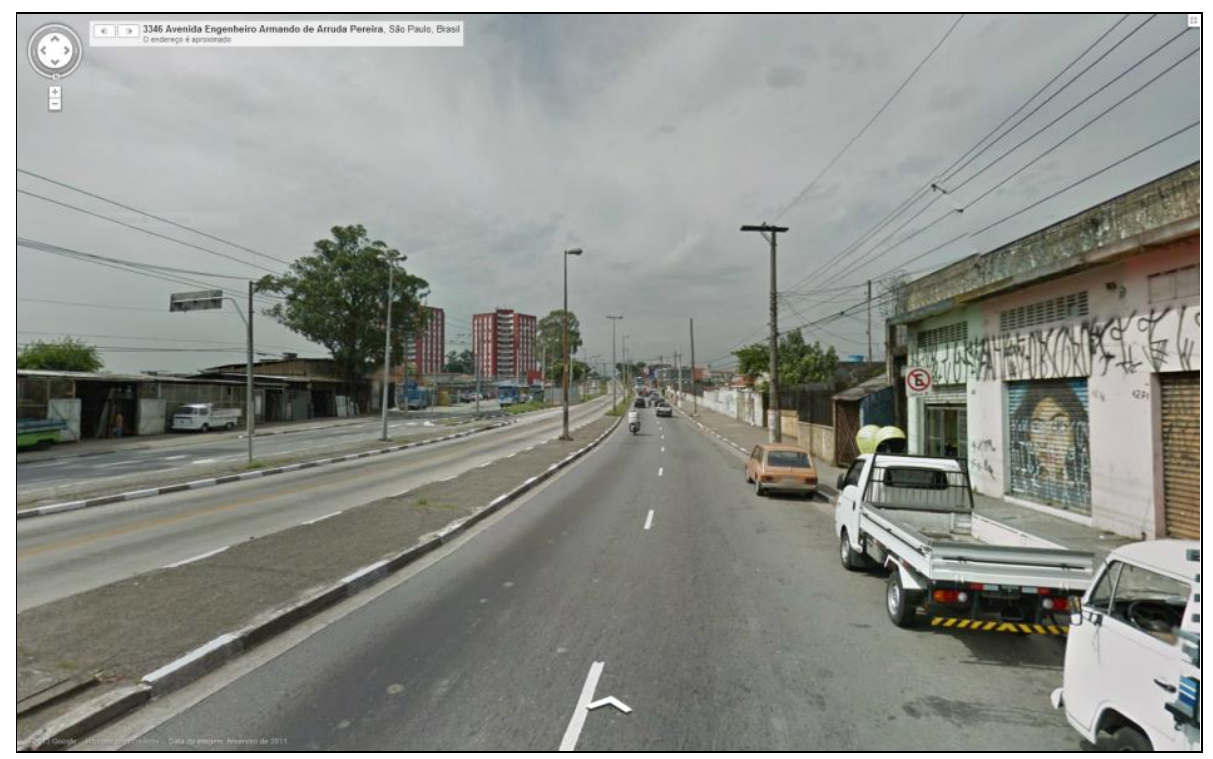

Figura 32 - Imagem do trecho A, na av. Eng. Armando de Arruda Pereira com corredor central de circulação exclusiva de ônibus (Google Street View).

A execução do experimento neste trecho ocorreu em $40,3 \%$ do tempo nos horários de pico e os resultados dos principais indicadores de deslocamento para os horários de pico e fora de pico foram muito diferentes, porém coerentes com a expectativa. A Tabela 15 mostra o resumo de ambas as condições.

Tabela 15 - Indicadores básicos das microviagens do trecho A para horários de pico e fora de pico.

\begin{tabular}{lcccc}
\hline & $\begin{array}{c}\text { Velocidade } \\
\text { Média } \\
\mathrm{km} / \mathrm{h}\end{array}$ & $\begin{array}{c}\text { Duração } \\
\text { média } \\
\text { microviagem }\end{array}$ & $\begin{array}{c}\text { Tempo parado } \\
\text { médio }\end{array}$ \\
\hline Pico & 13,0 & $\mathrm{~s}$ & $\mathrm{~s}$ & $\%$ \\
\hline Fora Pico & 19,6 & 102,0 & 13,2 & $21,6 \%$ \\
\hline Total Pico e Fora pico & 16,1 & 80,4 & 13,0 & $11,8 \%$ \\
\hline
\end{tabular}

Os dados obtidos durante o horário de pico mostram valores de velocidade média $34 \%$ inferiores àqueles registrados fora do pico, microviagens $40 \%$ mais curtas e maior tempo parado proporcionalmente. Esses resultados permitem concluir que, para esse trecho, há uma grande variação das condições de tráfego nos períodos do dia analisados.

Considerando que para o trecho $\mathrm{A}$ existem diferenças de tráfego que impactam de forma significativa principalmente nos resultados de velocidade média e duração das 
microviagens, a distribuição de VSP para o trecho A foi feita de forma separada para os horários de pico e fora de pico, conforme a Figura 33.

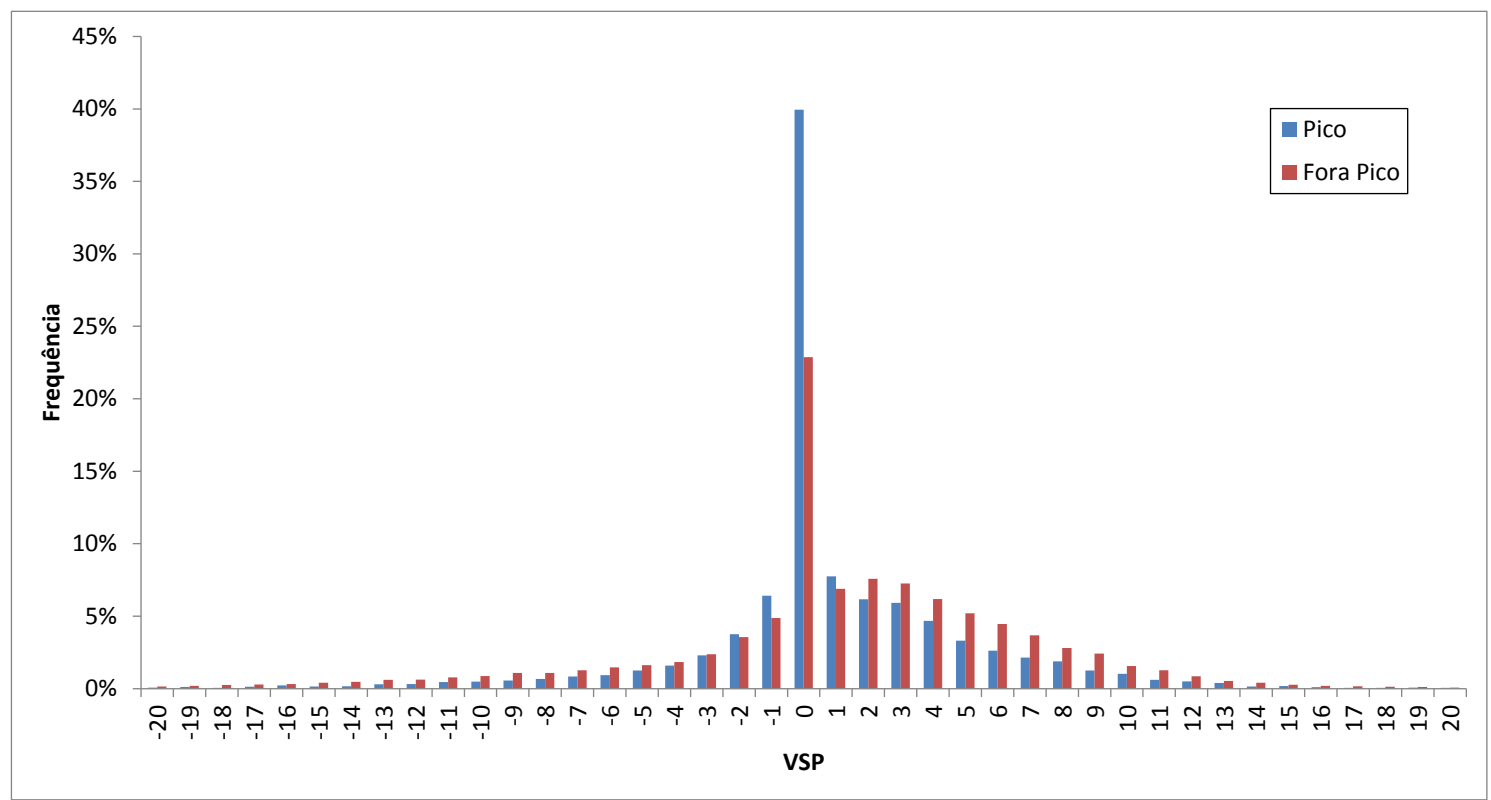

Figura 33 - Distribuição de VSP para o trecho A nos horários de pico e fora de pico.

Os resultados mostrados no gráfico da distribuição de VSP da Figura 33 reforçam a grande diferença de tempo parado para as condições de pico e fora de pico, sendo que praticamente toda esta diferença está distribuída nos valores de VSP positivos (veículo acelerando) para o período fora de pico. Por outro lado, o tempo em que o veículo permanece desacelerando (VSP negativo) durante os períodos de pico e fora de pico são semelhantes, conforme resultados detalhados na Tabela 16.

Tabela 16 - Distribuição das faixas de VSP para o trecho A nos horários de pico e fora de pico.

\begin{tabular}{ccc}
\hline Faixas de VSP & Pico & Fora Pico \\
\hline-20 a -11 & $2 \%$ & $4 \%$ \\
-10 a -1 & $19 \%$ & $20 \%$ \\
0 & $40 \%$ & $23 \%$ \\
1 a 10 & $37 \%$ & $48 \%$ \\
11 a 20 & $2 \%$ & $4 \%$ \\
\hline
\end{tabular}

Da mesma forma que a distribuição de VSP, as grandes diferenças observadas nos deslocamentos do veículo de testes nos períodos de pico e fora de pico considerados tornam mais adequado que seja construído um ciclo de condução para cada período. 


\subsubsection{Ciclos de condução para o trecho A}

O ciclo de condução para o trecho A nos períodos de pico, mostrado na Figura 34, foi formado por 12 microviagens com duração média de 102 segundos, com aproximadamente $30,4 \%$ de tempo parado e velocidade média de $16,7 \pm 16,2 \mathrm{~km} / \mathrm{h}$ (coeficiente de variação, $c v=0,97$ ).

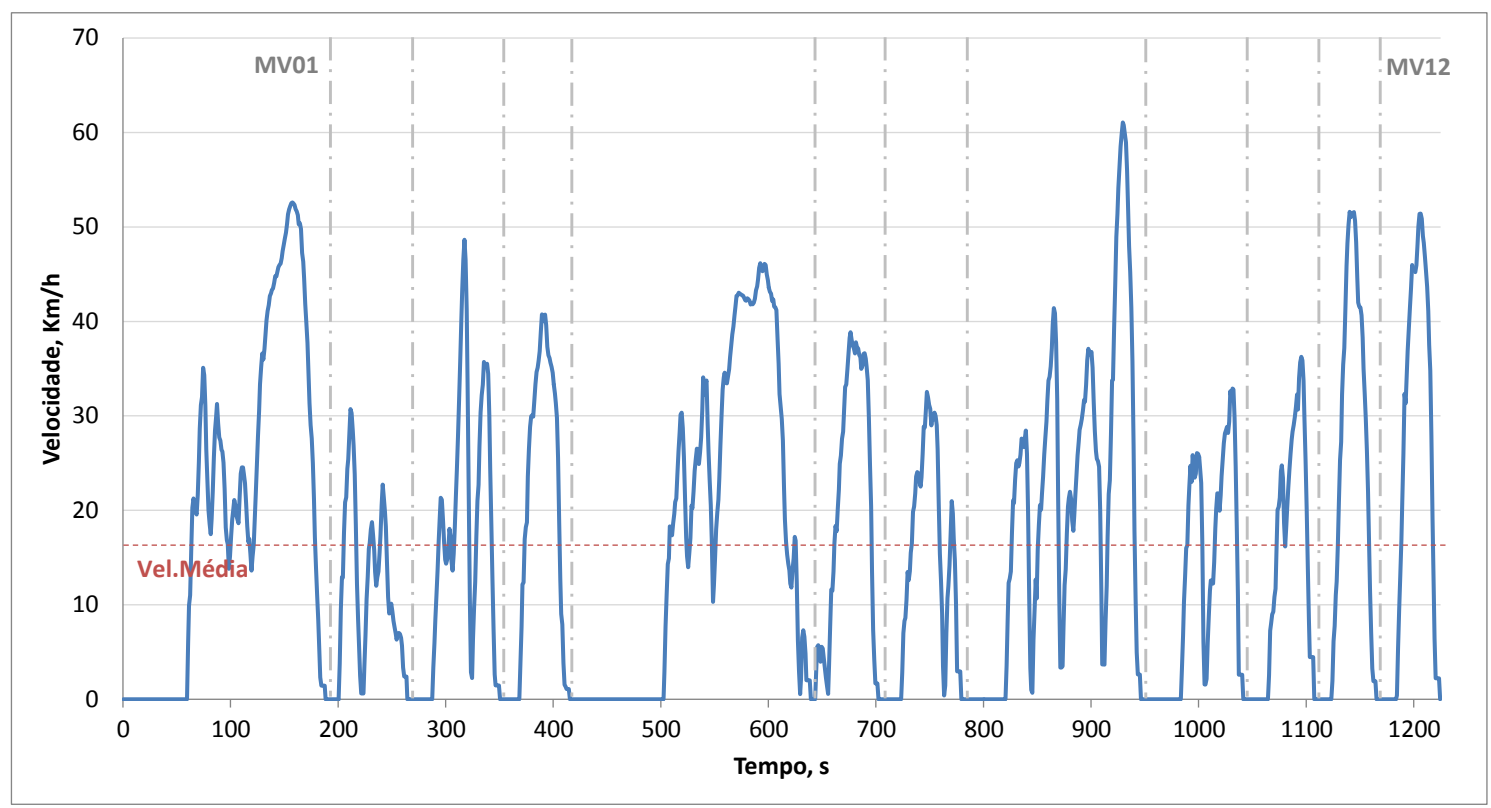

Figura 34 - Ciclo de condução para o trecho A nos horários de pico.

A Tabela 17 mostra a comparação das faixas de VSP para o trecho A nos horários de pico, considerando a amostra total para este trecho e período, e o ciclo construído para essa condição, onde é possível verificar a semelhança dos resultados.

Tabela 17 - Distribuição das faixas de VSP para os horários de pico no trecho A, na amostra total e no ciclo construído.

\begin{tabular}{crc}
\hline Faixas de VSP & Total & Ciclo \\
\hline-20 a 11 & $2,0 \%$ & $1,2 \%$ \\
-10 a 1 & $18,8 \%$ & $19,4 \%$ \\
0 & $39,9 \%$ & $41,6 \%$ \\
1 a 10 & $36,8 \%$ & $36,2 \%$ \\
11 a 20 & $2,2 \%$ & $1,6 \%$ \\
\hline
\end{tabular}


Já para os horários fora de pico, o ciclo de condução mostrado na Figura 35, apresenta velocidade média foi $25,2 \pm 16,6 \mathrm{~km} / \mathrm{h}(\mathrm{cv}=0,66)$ e a duração média das microviagens foi de 247 segundos com $11,3 \%$ de tempo parado, com um total de cinco microviagens.

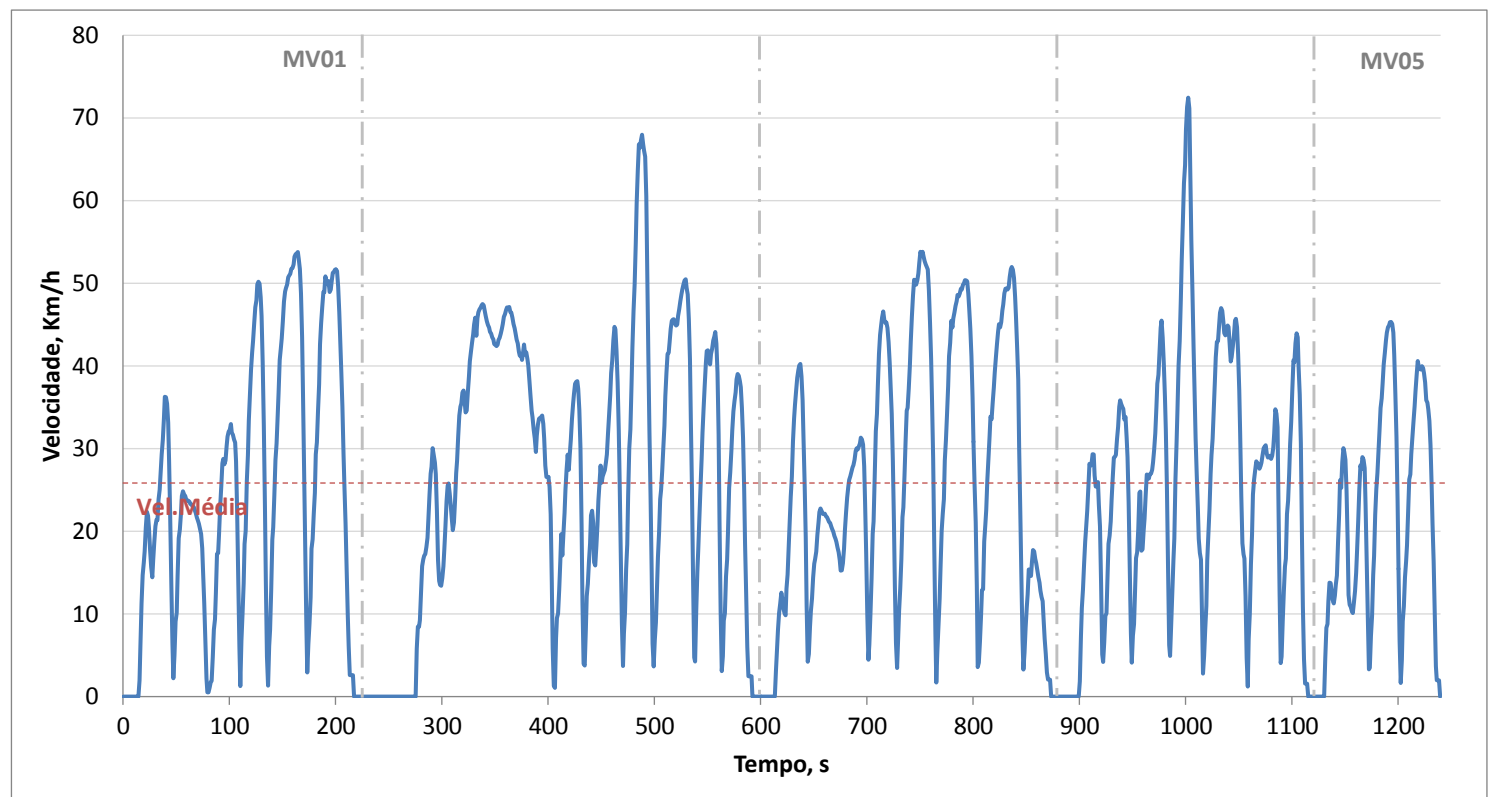

Figura 35 - Ciclo de condução para o trecho A fora dos horários de pico.

Para verificar a representatividade do ciclo em termos de VSP, a Tabela 18 abaixo compara as distribuições de VSP para a amostra de dados do trecho A fora do horário de pico e para o ciclo de condução construído para este trecho neste período.

Tabela 18 - Distribuição das faixas de VSP para os horários fora de pico no trecho A, na amostra total e no ciclo construído.

\begin{tabular}{ccc}
\hline Faixas de VSP & Total & Ciclo \\
\hline-20 a 11 & $4,1 \%$ & $4,4 \%$ \\
-10 a 1 & $20,1 \%$ & $19,6 \%$ \\
0 & $22,9 \%$ & $21,6 \%$ \\
1 a 10 & $48,1 \%$ & $50,1 \%$ \\
11 a 20 & $4,0 \%$ & $3,7 \%$ \\
\hline
\end{tabular}

Com base nos dados gerais de deslocamento do trecho A para os horários de pico e fora de pico e nos ciclos de condução mostrados nas Figuras 34 e 35, verifica-se nos horários de pico a tendência de maior tempo parado e maior variabilidade da velocidade. 


\subsubsection{Trecho B - Avenidas Prestes Maia (Diadema) e Taboão (São Bernardo do Campo)}

O trecho $B$ foi formado pelo percurso entre os pontos $A$ e $B$ da Figura 35, percorrido nas avenidas Prestes Maia, em Diadema, e Taboão, em São Bernardo do Campo, com extensão de $5 \mathrm{~km}$. Durante o experimento o veículo de testes circulou em ambos os sentidos e armazenou dados de 58.611 segundos (aprox. 971 minutos, em 698 microviagens) de movimentação neste trecho.

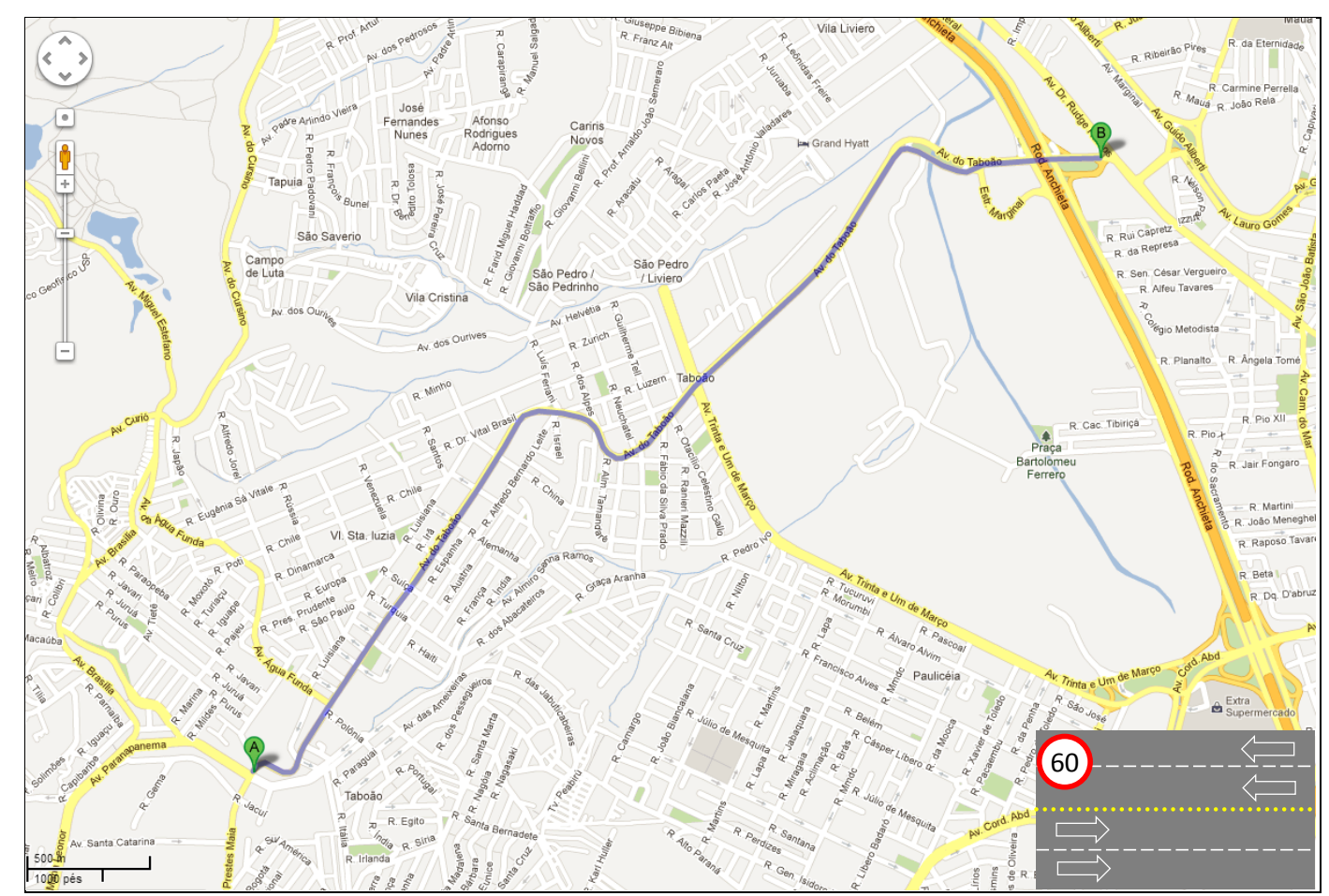

Figura 36 - Trecho B - Av. Prestes Maia / Av. do Taboão - (São Bernardo do Campo/Diadema) Percorrida em ambos os sentidos.

O trecho $B$ tem em sua extensão a predominância de duas faixas de rolamento em cada sentido, separadas por tachões (conhecidos como "tartarugas"), mostrado na Figura 37, o que reduz a capacidade e, portanto, a velocidade da via. 


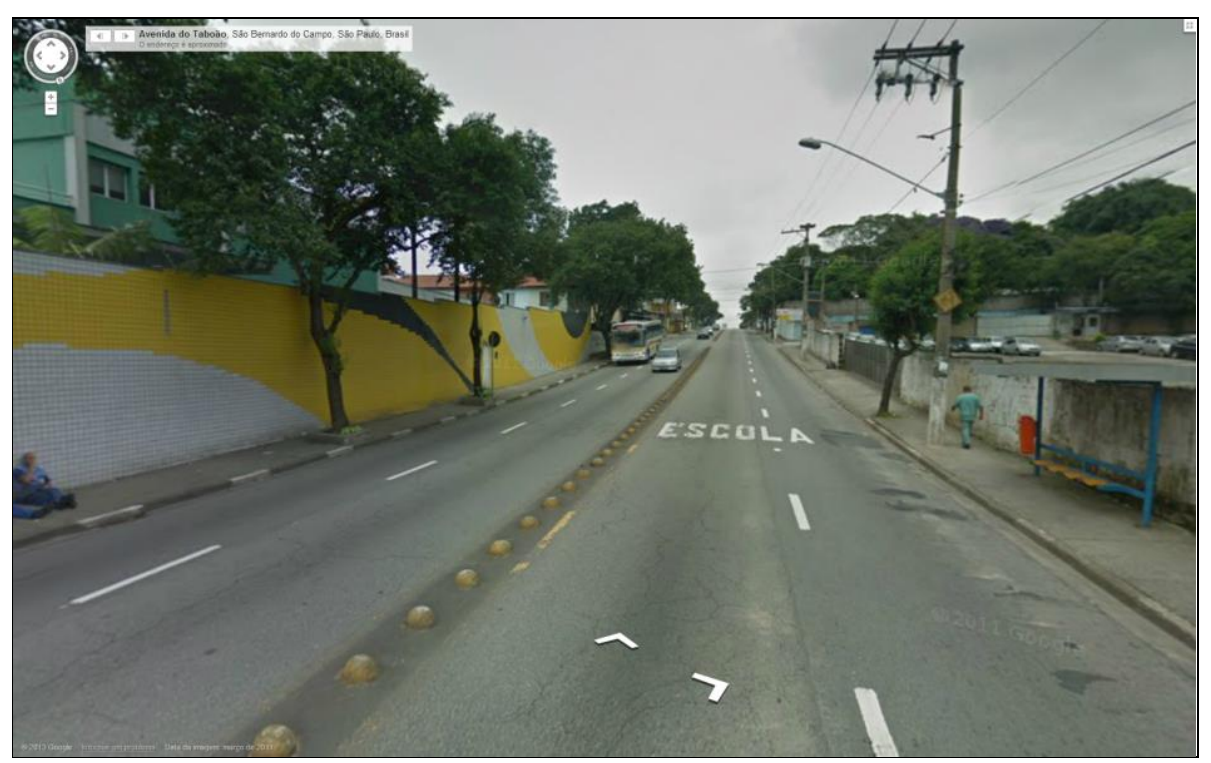

Figura 37 - Imagem da Avenida do Taboão, em São Bernardo do Campo, parte do trecho B. Separação por "tartarugas" impede ultrapassagens pela contramão (Google Street View).

Em 36,4\% do tempo o trecho $B$ foi percorrido no horário de pico e, de forma geral, os indicadores de velocidade média e tempo parado não variaram consideravelmente durante os períodos do dia, apresentando um aumento de 7\% na duração média das microviagens para os períodos fora do pico, indicando que, para esse trajeto, não existem grandes diferenças de tráfego durante os diversos períodos do dia. Os dados-resumo para os períodos nas condições de pico e fora de pico para o trecho B podem ser verificados na Tabela 19.

Tabela 19 - Indicadores básicos das microviagens do trecho B para horários de pico e fora de pico.

\begin{tabular}{lcccc}
\hline & $\begin{array}{c}\text { Velocidade } \\
\text { Média }\end{array}$ & $\begin{array}{c}\text { Duração } \\
\text { média } \\
\text { microviagem }\end{array}$ & \multicolumn{2}{c}{$\begin{array}{c}\text { Tempo parado } \\
\text { médio }\end{array}$} \\
\hline Pico & 13,3 & $\mathrm{~s}$ & $\mathrm{~s}$ & $\%$ \\
\hline Fora Pico & 13,4 & 80,3 & 20,7 & $25,8 \%$ \\
\hline Total Pico e Fora pico & 13,3 & 84,2 & 22,0 & $25,5 \%$ \\
\hline
\end{tabular}

Em concordância com as informações básicas fornecidas na tabela anterior, verificase através das distribuições de VSP para os períodos de pico e fora de pico, apresentadas na Figura 37, grande semelhança entre as duas condições. 


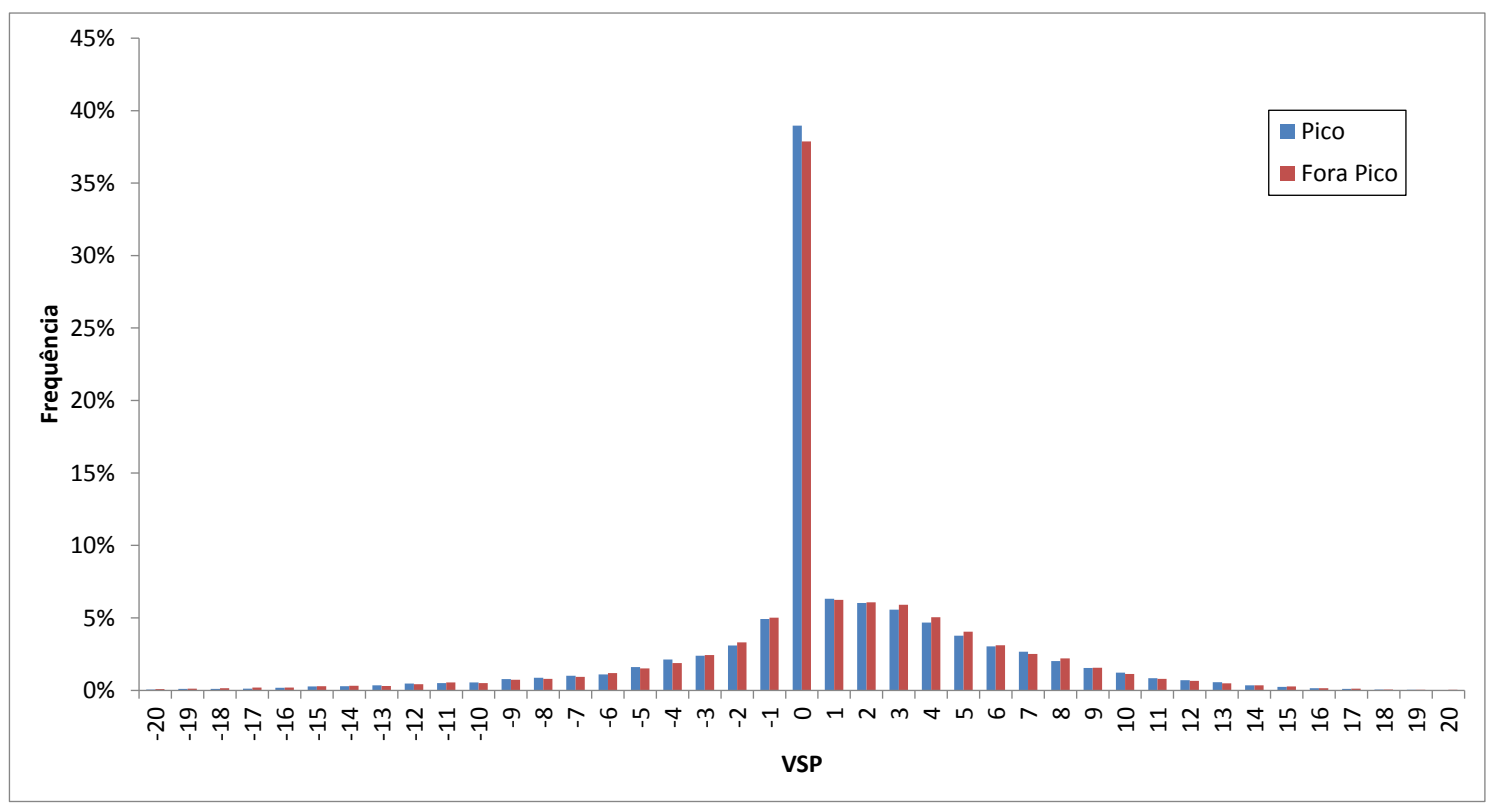

Figura 38 - Distribuição de VSP para o trecho B nos horários de pico e fora de pico.

Considerando que a variação de tráfego nas condições de pico e fora de pico para o trecho B mapeado resulta em impacto reduzido para as distribuições de VSP e também nos indicadores gerais de deslocamento do veículo de testes, foi desenvolvido para este trecho somente um ciclo de condução que pudesse representar a variação de velocidade de forma confiável, seguindo a metodologia desenvolvida por Lai et al. (2012).

\subsubsection{Ciclo de condução para o trecho B}

O único ciclo desenvolvido para o trecho B, mostrado na Figura 39, foi composto por oito microviagens de duração média de 136 segundos, com média de $26,5 \%$ de tempo parado e velocidade média de $17,1 \pm 15,7 \mathrm{~km} / \mathrm{h}(\mathrm{cv}=0,92)$. 


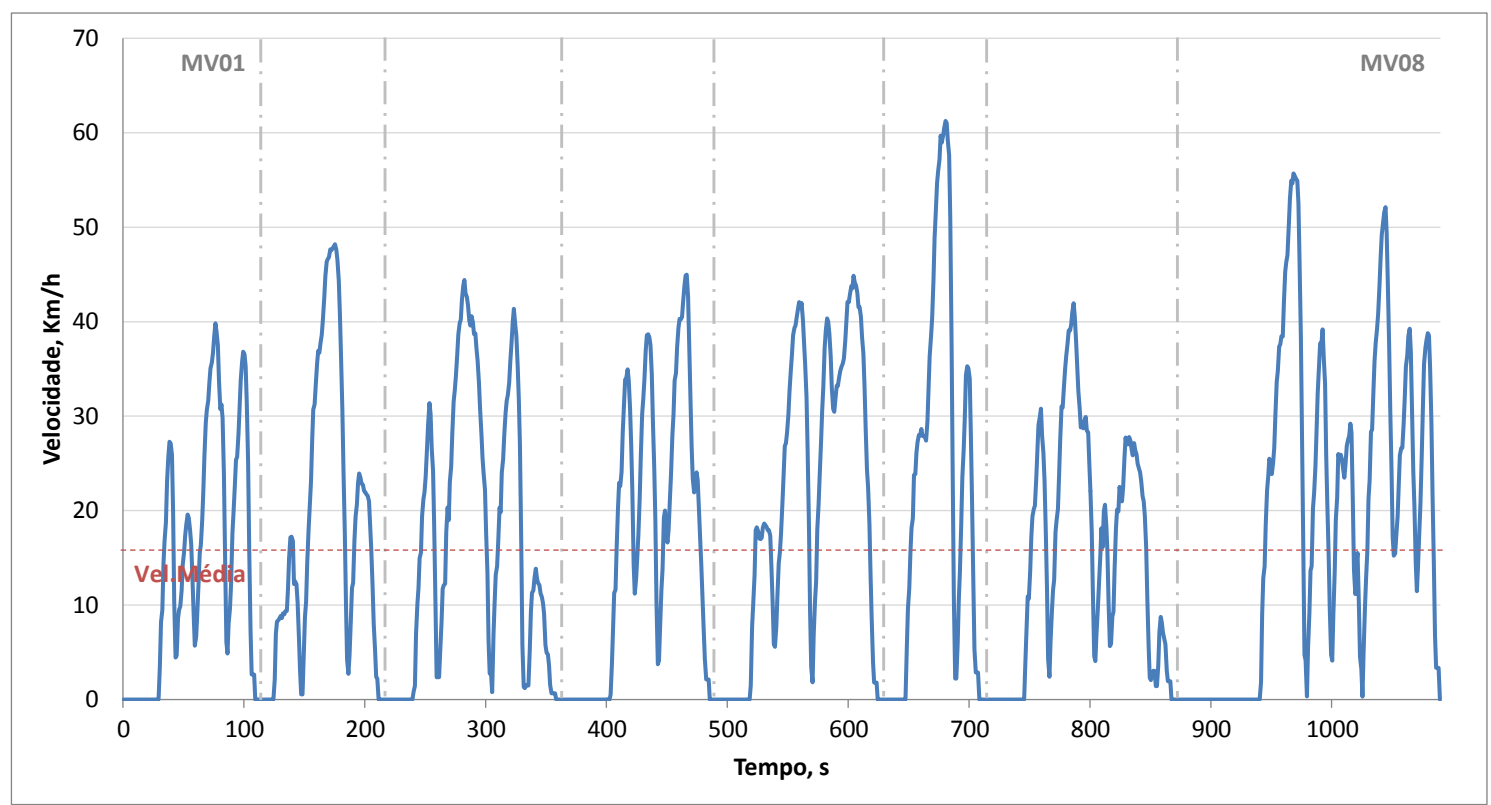

Figura 39 - Ciclo de condução para o trecho B

A Tabela 20 a seguir mostra a comparação das faixas de VSP para o trecho $\mathrm{B}$, considerando a amostra total para este trecho e o ciclo construído para essa condição, onde é possível verificar a semelhança dos resultados.

Tabela 20 - Distribuição das faixas de VSP para o trecho B, na amostra total e no ciclo construído.

\begin{tabular}{ccc}
\hline Faixas de VSP & Total & Ciclo \\
\hline-20 a 11 & $2,6 \%$ & $2,7 \%$ \\
-10 a 1 & $18,4 \%$ & $18,0 \%$ \\
0 & $38,3 \%$ & $38,3 \%$ \\
1 a 10 & $37,5 \%$ & $39,1 \%$ \\
11 a 20 & $3,0 \%$ & $2,0 \%$ \\
\hline
\end{tabular}




\subsubsection{Trecho C - Avenida do Cursino (São Paulo)}

A Figura 40 mostra o trajeto entre os pontos A e B, na avenida do Cursino (São Paulo), que compõe o trecho $\mathrm{C}$ do experimento. Este trecho foi percorrido somente no sentido $A-B$, que soma $6,8 \mathrm{~km}$ de extensão. Para este trecho foram adquiridos 49.260s (821 minutos em 562 microviagens) de dados de deslocamento.

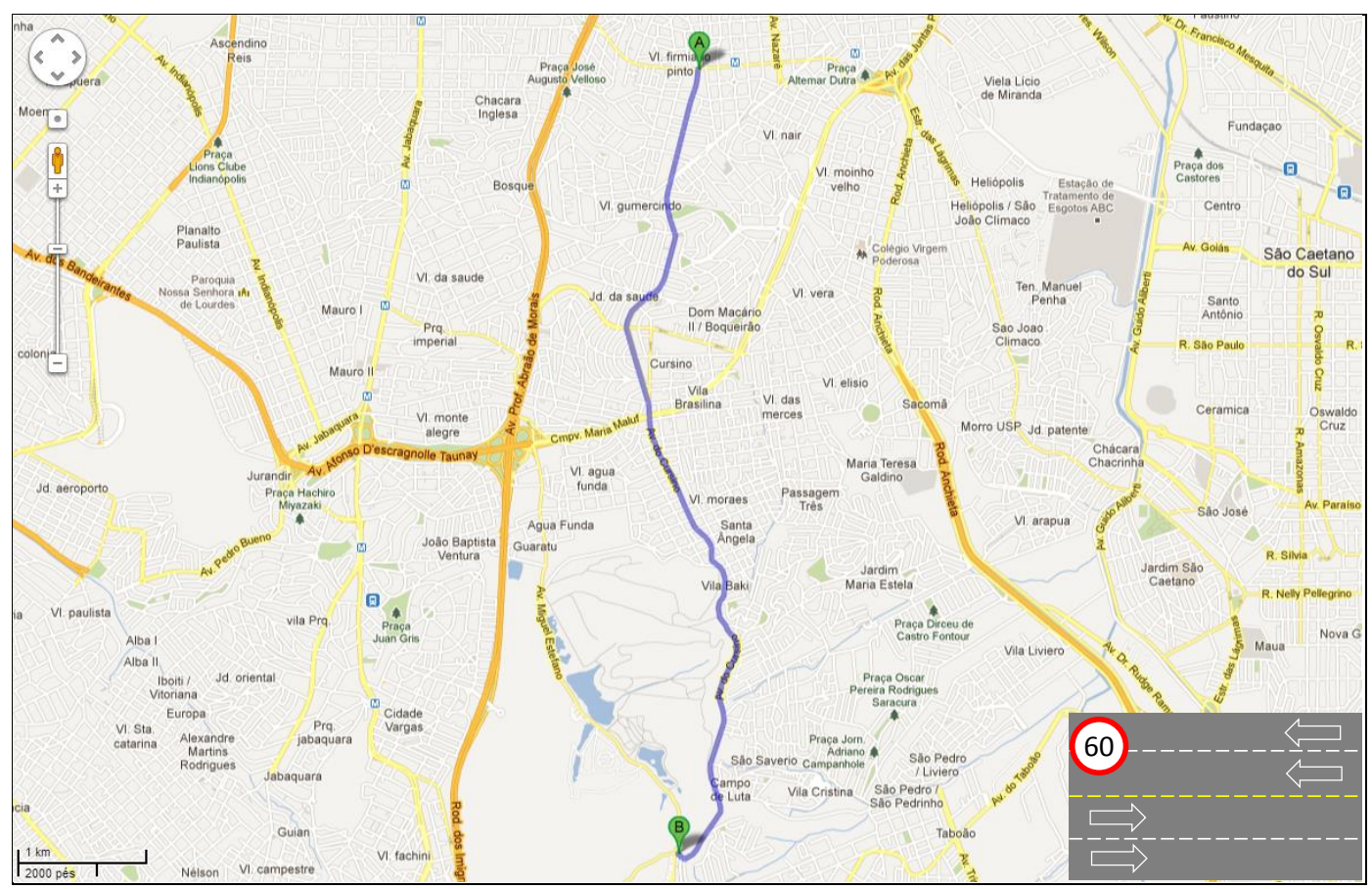

Figura 40 - Trecho C - Av. do Cursino (São Paulo) - Percorrida somente no sentido A-B.

A avenida do Cursino apresenta na maior parte de sua extensão duas faixas de rolamento em cada sentido sem separação física, Figura 41(a), porém alguns segmentos possuem canteiro central, como pode ser visto na Figura 41(b).

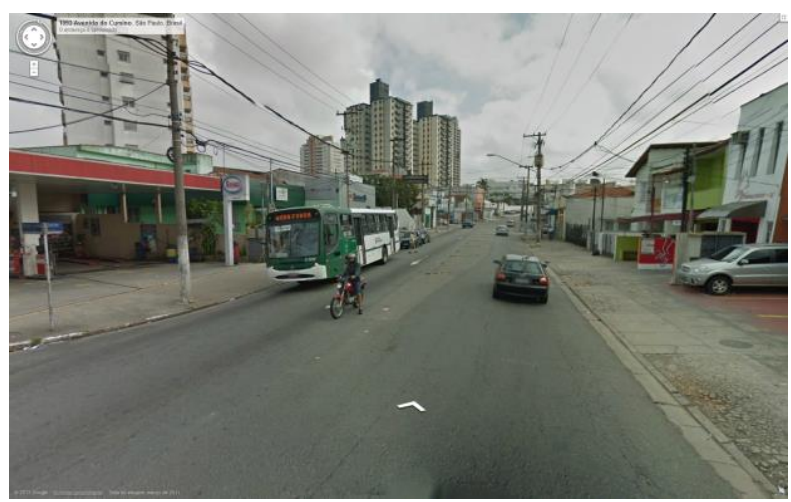

(a)

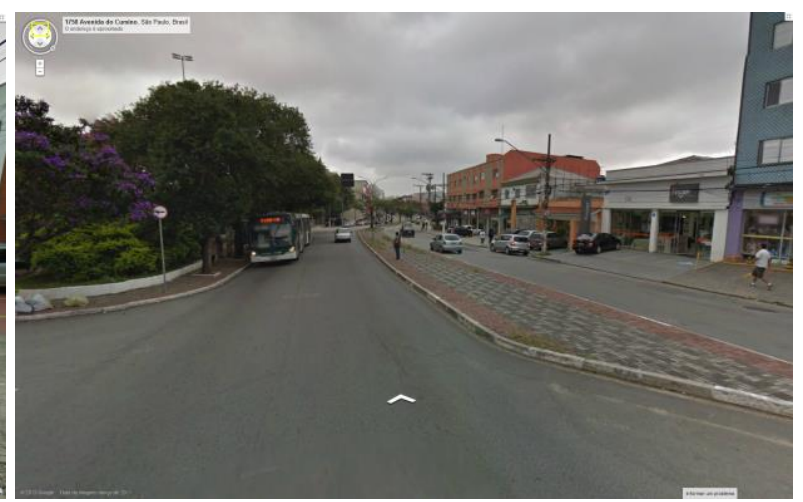

(b)

Figura 41 - Imagem da av. do Cursino, trecho C, em dois pontos distintos (Google Street View). 
O trecho $\mathrm{C}$ foi percorrido fora do horário de pico na maior parte do tempo, $65,7 \%$, porém os resultados das medições de velocidade do ônibus de testes em ambos os períodos (pico e fora de pico) não apresentaram grandes variações. A Tabela 21 a seguir mostra que, diferente do esperado, a velocidade média para o horário de pico, de $17,2 \mathrm{~km} / \mathrm{h}$, é superior à registrada fora do pico em $15,1 \%$ e com variação da duração média de 10\%.

Tabela 21 - Indicadores básicos das microviagens do trecho C para horários de pico e fora de pico.

\begin{tabular}{lcccc}
\hline & $\begin{array}{c}\text { Velocidade } \\
\text { Média } \\
\mathrm{km} / \mathrm{h}\end{array}$ & $\begin{array}{c}\text { Duração } \\
\text { média } \\
\text { microviagem }\end{array}$ & $\begin{array}{c}\text { Tempo parado } \\
\text { médio }\end{array}$ \\
\hline Pico & 17,2 & 81,7 & $\mathrm{~s}$ & $\%$ \\
Fora Pico & 14,6 & 91,1 & 16,3 & $20,0 \%$ \\
\hline Total Pico e Fora pico & 15,6 & 87,7 & 15,8 & $17,0 \%$ \\
\hline
\end{tabular}

Desta forma, as distribuições de VSP para os horários de pico e fora de pico para o trecho C, mostradas na Figura 42, apresentam resultados semelhantes. Em cada caixa de VSP verificou-se pequenas diferenças, o que também pode ser verificado na Tabela 22.

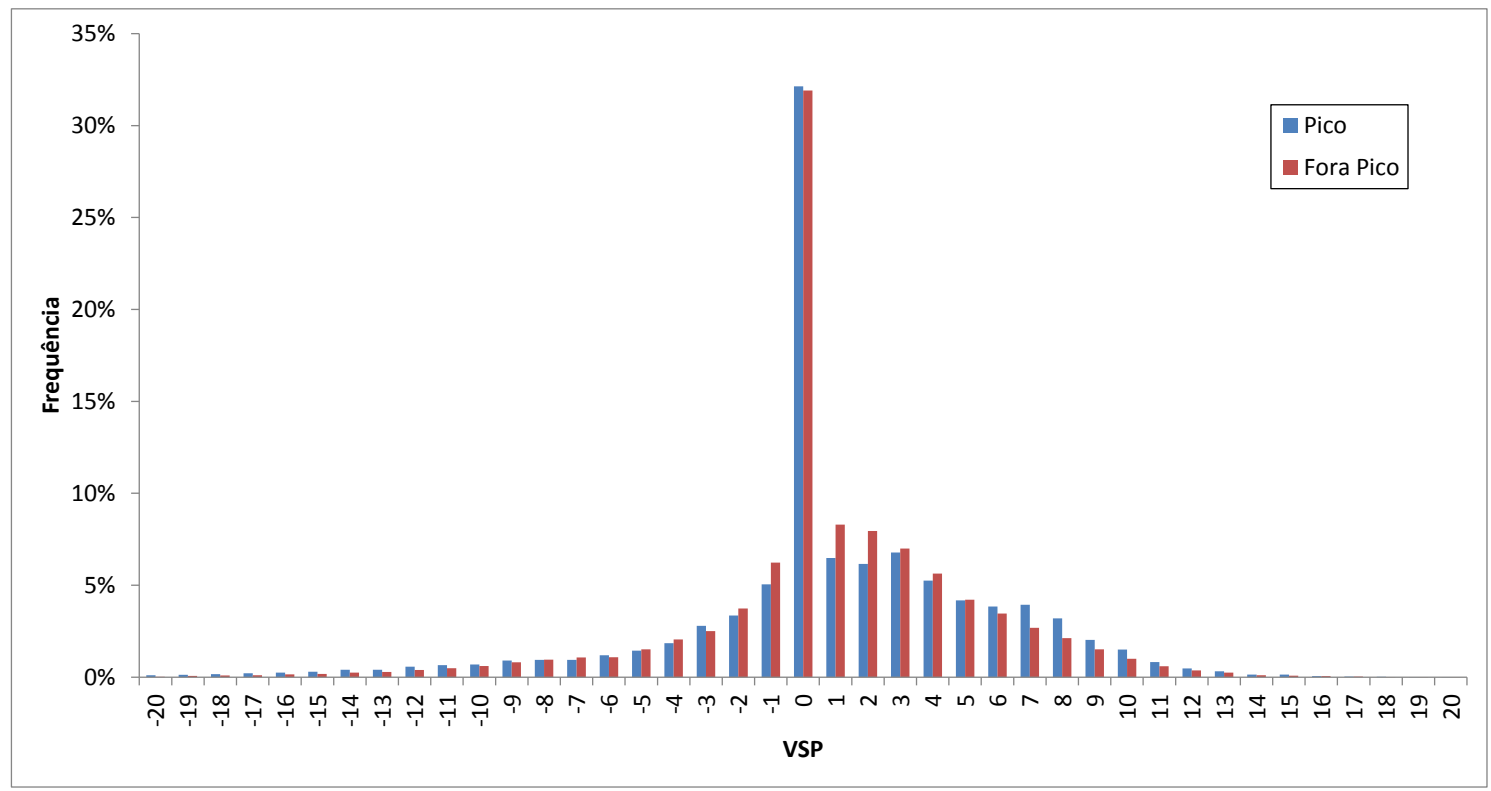

Figura 42 - Distribuição de VSP para o trecho C nos horários de pico e fora de pico. 
Assim, da mesma maneira que o trecho $B$, como ambos os horários não apresentaram grandes diferenças nos indicadores de deslocamento e VSP, concluise que para esse trecho não são verificadas grandes variações de condições de tráfego ao longo do dia e, desta forma, pode ser elaborado um único ciclo de condução para representar as variações de velocidade do percurso no tempo.

Tabela 22 - Distribuição das faixas de VSP para o trecho C nos horários de pico e fora de pico.

\begin{tabular}{ccc}
\hline Faixas de VSP & Pico & Fora Pico \\
\hline-20 a -11 & $3 \%$ & $2 \%$ \\
-10 a -1 & $19 \%$ & $21 \%$ \\
0 & $32 \%$ & $32 \%$ \\
1 a 10 & $43 \%$ & $44 \%$ \\
11 a 20 & $2 \%$ & $2 \%$ \\
\hline
\end{tabular}

\subsubsection{Ciclo de condução para o trecho C}

Para o trecho C, na Figura 43, o ciclo de condução desenvolvido foi formado por nove microviagens de duração média de 123 segundos, em um total de 1109, com uma proporção de tempo parado de $21,1 \%$. A velocidade média resultante neste ciclo de condução foi de $18,7 \pm 14,9 \mathrm{~km} / \mathrm{h}(\mathrm{cv}=0,80)$.

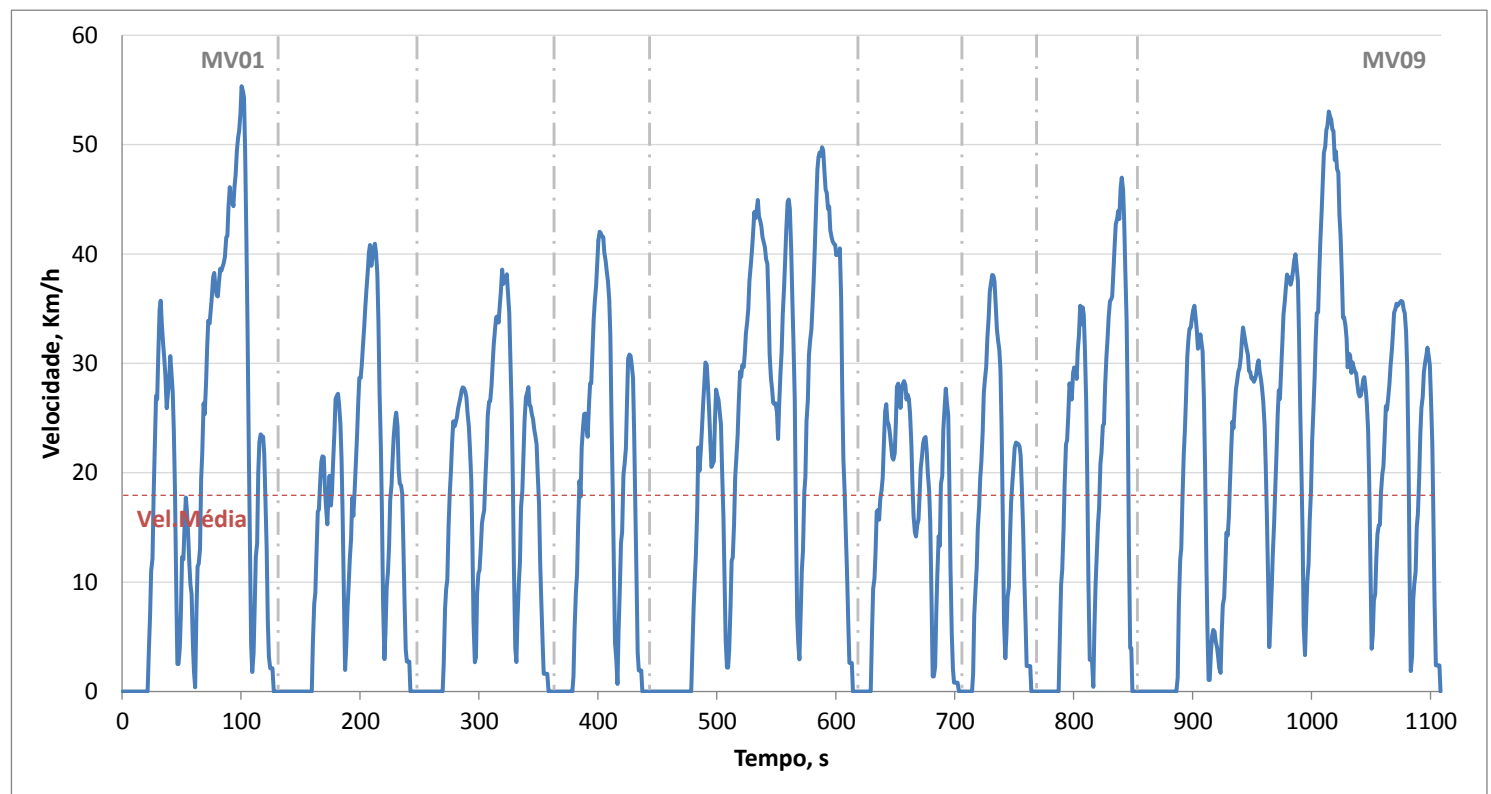

Figura 43 - Ciclo de condução para o trecho C. 
Para verificar a representatividade do ciclo em termos de VSP, a Tabela 23 compara as distribuições de VSP para a amostra de dados do trecho $\mathrm{C}$ e para o ciclo de condução construído para este trecho.

Tabela 23 - Distribuição das faixas de VSP para o trecho C, na amostra total e no ciclo construído.

\begin{tabular}{ccc}
\hline Faixas de VSP & Total & Ciclo \\
\hline-20 a 11 & $2,4 \%$ & $1,6 \%$ \\
-10 a 1 & $20,1 \%$ & $22,5 \%$ \\
0 & $32,0 \%$ & $31,0 \%$ \\
1 a 10 & $43,7 \%$ & $43,5 \%$ \\
11 a 20 & $1,7 \%$ & $1,4 \%$ \\
\hline
\end{tabular}




\subsubsection{Trecho D - Av. José Cabalero, R. Cel. Alfredo Flaquer, Av. Santos}

\section{Dumont, R Giovanni Battista Pirelli e Av. João Ramalho (Santo André)}

Apesar das diversas mudanças de nome, o trecho D, na Figura 44, é uma sequência de vias com características semelhantes, que foram percorridas em ambas as direções, e que se estendem por 7,4km no município de Santo André. Para este trecho foram registrados 72.589 segundos (1210 minutos em 730 microviagens) de dados do deslocamento do ônibus de teste.

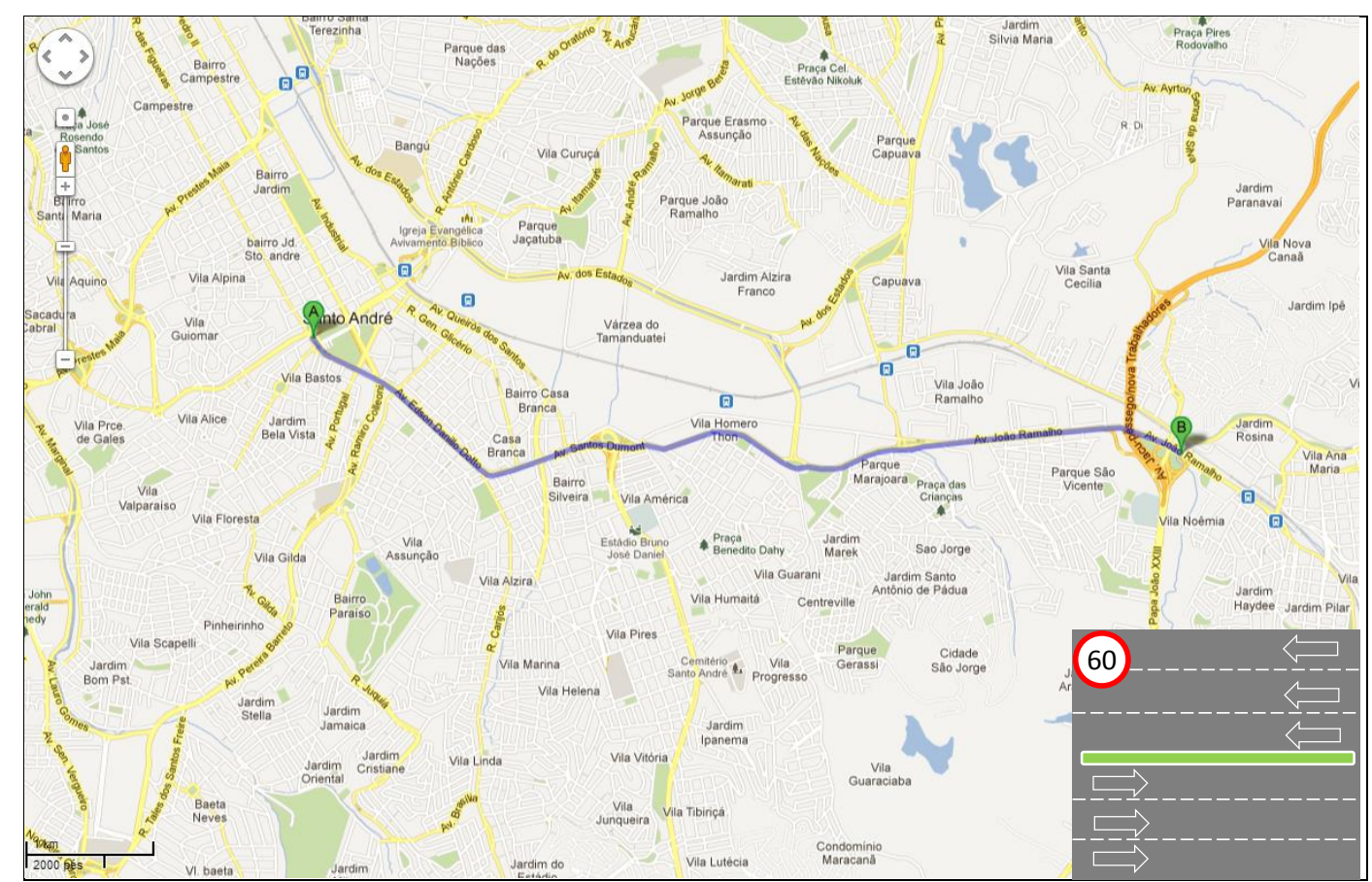

Figura 44 - Trecho D - Av. José Cabalero / R. Cel. Alfredo Flaquer / Av. Santos Dumont / R. Giovanni Battista Pirelli / Av. João Ramalho (Santo André) - Percorrida em ambas as direções A-B.

As vias que compõem o trecho $D$ são grandes avenidas formadas em sua maior parte por ao menos três faixas de rolamento em cada sentido, com separação por canteiro central e velocidade máxima permitida de $60 \mathrm{~km} / \mathrm{h}$, conforme o detalhe no canto direito inferior da Figura 44 e exemplo mostrado na Figura 45. 


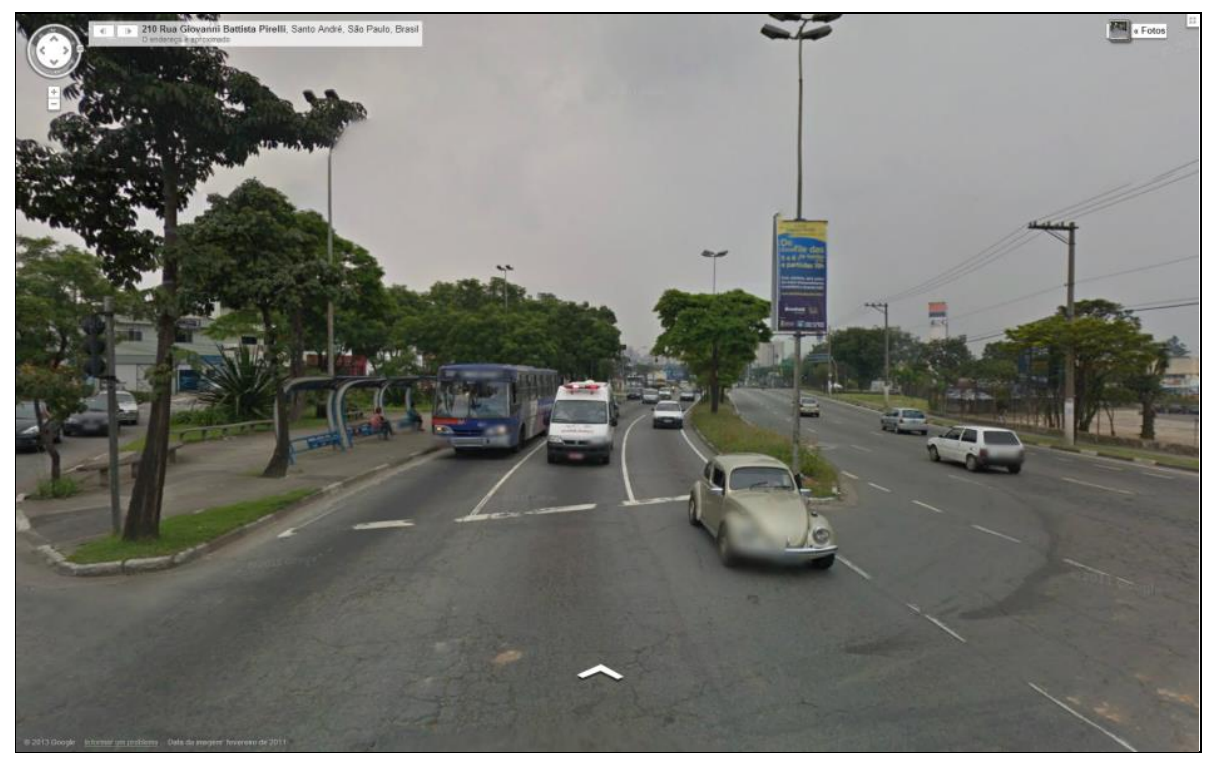

Figura 45 - Imagem do trecho D, Av. Giovanni Battista Pirelli (Google Street View).

O experimento no trecho $\mathrm{D}$ foi realizado predominantemente nos horários de pico, em aproximadamente $73 \%$ do total, e o resumo dos dados deste trajeto para os diferentes horários foram condizentes com a expectativa. Nos horários de pico a velocidade média foi $20 \%$ inferior, as microviagens foram $11,1 \%$ mais curtas e 0 tempo parado proporcionalmente 35\% maior, em relação aos horários fora do pico. A Tabela 24 mostra o resumo dessas informações para os diferentes horários e para o total de dados adquiridos.

Tabela 24 - Indicadores básicos das microviagens do trecho D para horários de pico e fora de pico.

\begin{tabular}{lcccc}
\hline & $\begin{array}{c}\text { Velocidade } \\
\text { Média } \\
\mathrm{km} / \mathrm{h}\end{array}$ & $\begin{array}{c}\text { Duração } \\
\text { média } \\
\text { microviagem }\end{array}$ & $\begin{array}{c}\text { Tempo parado } \\
\text { médio }\end{array}$ \\
\hline Pico & 17,6 & $\mathrm{~s}$ & $\mathrm{~s}$ & $\%$ \\
\hline Fora Pico & 21,9 & 107,8 & 21,0 & $21,9 \%$ \\
\hline Total Pico e Fora pico & 18,7 & 98,8 & 17,5 & $16,2 \%$ \\
\hline
\end{tabular}

Além dos dados apresentados anteriormente, que mostram as diferenças dos horários de pico e fora de pico, as distribuições de VSP para estes horários no trecho D, apresentada na Figura 46, também confirma o maior percentual de tempo parado para o horário de pico, já que os valores de VSP iguais a zero são de $34 \%$ e $26 \%$ respectivamente para pico e fora de pico. 
Em ambas as condições - pico e fora de pico -, apesar do grande percentual de tempo parado, o veículo permanece a maior parte do tempo acelerando, ou seja, com valores de VSP maiores que zero (43\% e 50\% respectivamente). O percentual do tempo em que o veículo tem VSP menor que zero é muito semelhante para as duas situações ( $23 \%$ e $24 \%)$.

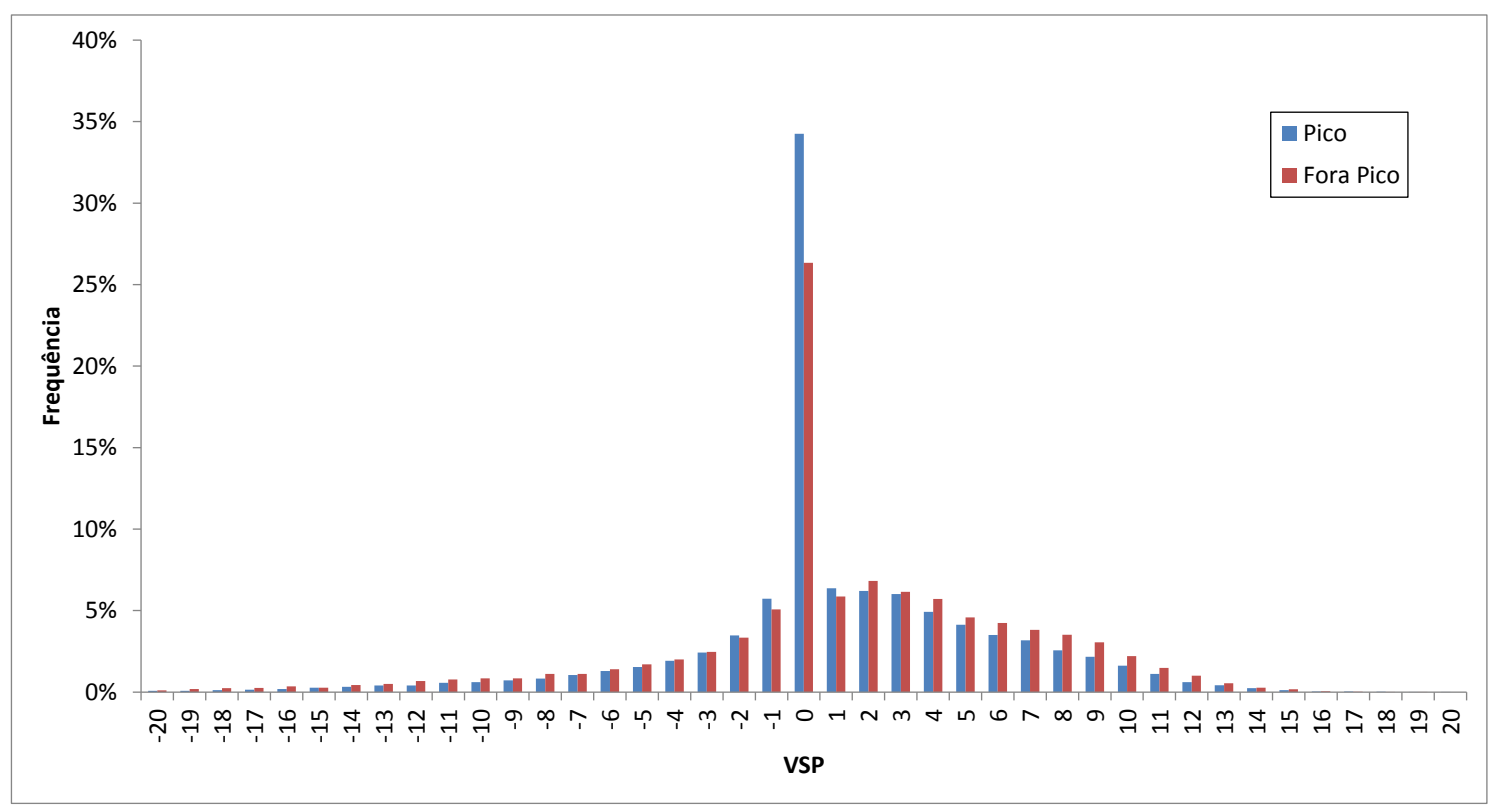

Figura 46 - Distribuição de VSP para o trecho D nos horários de pico e fora de pico.

Com a identificação de que os diferentes horários impactam consideravelmente nas condições de tráfego e consequentemente nos dados de deslocamento para o trecho $\mathrm{D}$, a determinação de um ciclo de condução para cada período é mais adequada para este trajeto.

\subsubsection{Ciclos de condução para o trecho $D$}

A Figura 47 mostra o ciclo de condução para o trecho $D$ nos períodos de pico. Este ciclo foi formado a partir de 13 microviagens de duração média de 99 segundos, com tempo parado médio de $26,2 \%$ e velocidade média de $22 \pm 19,8 \mathrm{~km} / \mathrm{h}(\mathrm{cv}=0,90)$. 


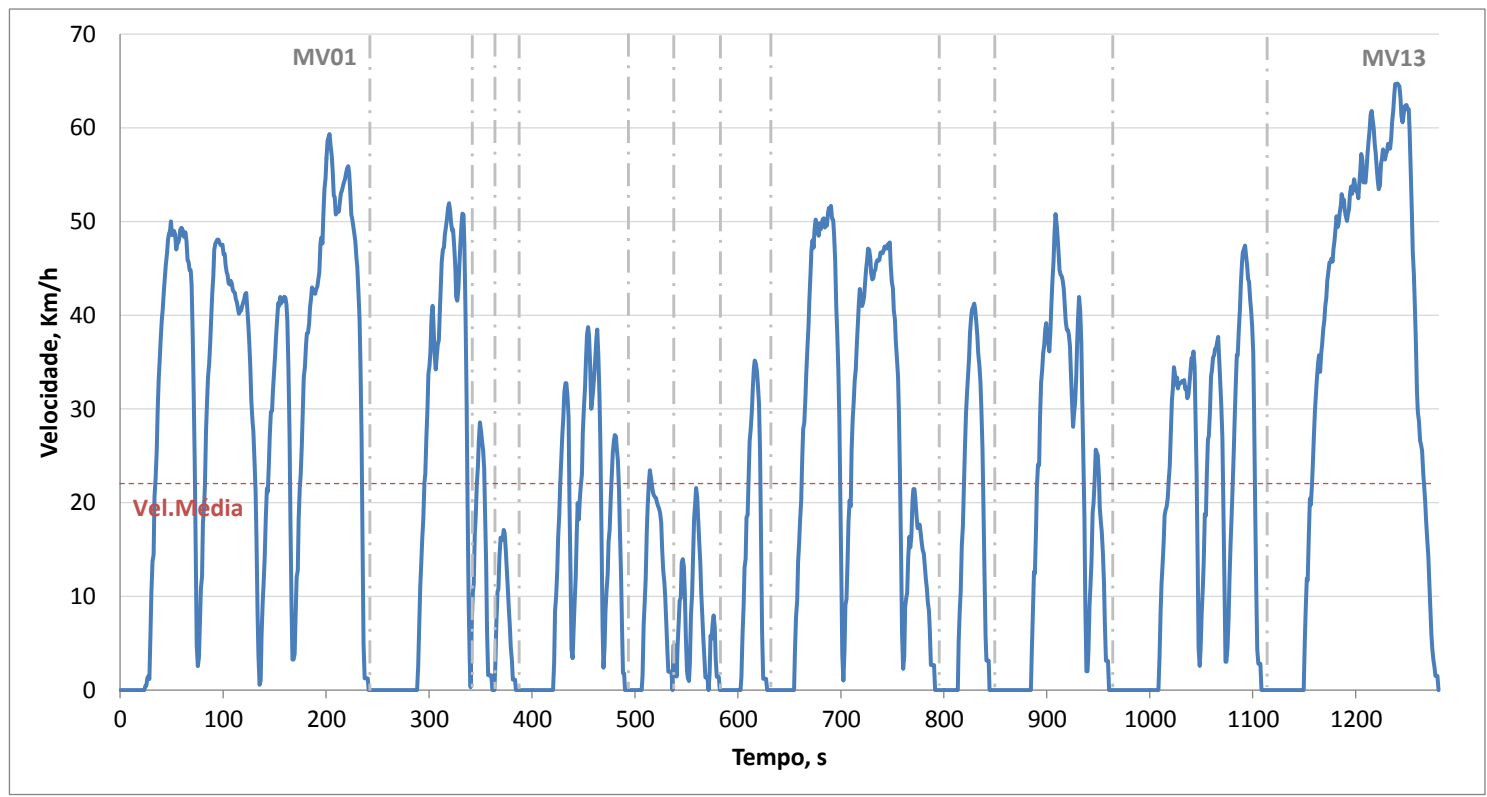

Figura 47 - Ciclo de condução para o trecho D nos horários de pico.

A Tabela 25 a seguir mostra a comparação das faixas de VSP para o trecho D nos horários de pico, considerando a amostra total para este trecho e período, e o ciclo construído para essa condição, onde é possível verificar a semelhança dos resultados.

Tabela 25 - Distribuição das faixas de VSP para os horários de pico no trecho D, na amostra total e no ciclo construído.

\begin{tabular}{ccc}
\hline Faixas de VSP & Total & Ciclo \\
\hline-20 a 11 & $2,6 \%$ & $2,4 \%$ \\
-10 a 1 & $19,6 \%$ & $20,3 \%$ \\
0 & $34,3 \%$ & $35,4 \%$ \\
1 a 10 & $40,7 \%$ & $40,0 \%$ \\
11 a 20 & $2,6 \%$ & $1,9 \%$ \\
\hline
\end{tabular}

Já para os períodos fora de pico, o ciclo de condução mostrado na Figura 48 foi composto por nove microviagens com duração média de 135 segundos e $14,7 \%$ de tempo parado médio. A velocidade média registrada para esse ciclo foi de $26,6 \pm$ $19,4 \mathrm{~km} / \mathrm{h}(\mathrm{cv}=0,73)$. 


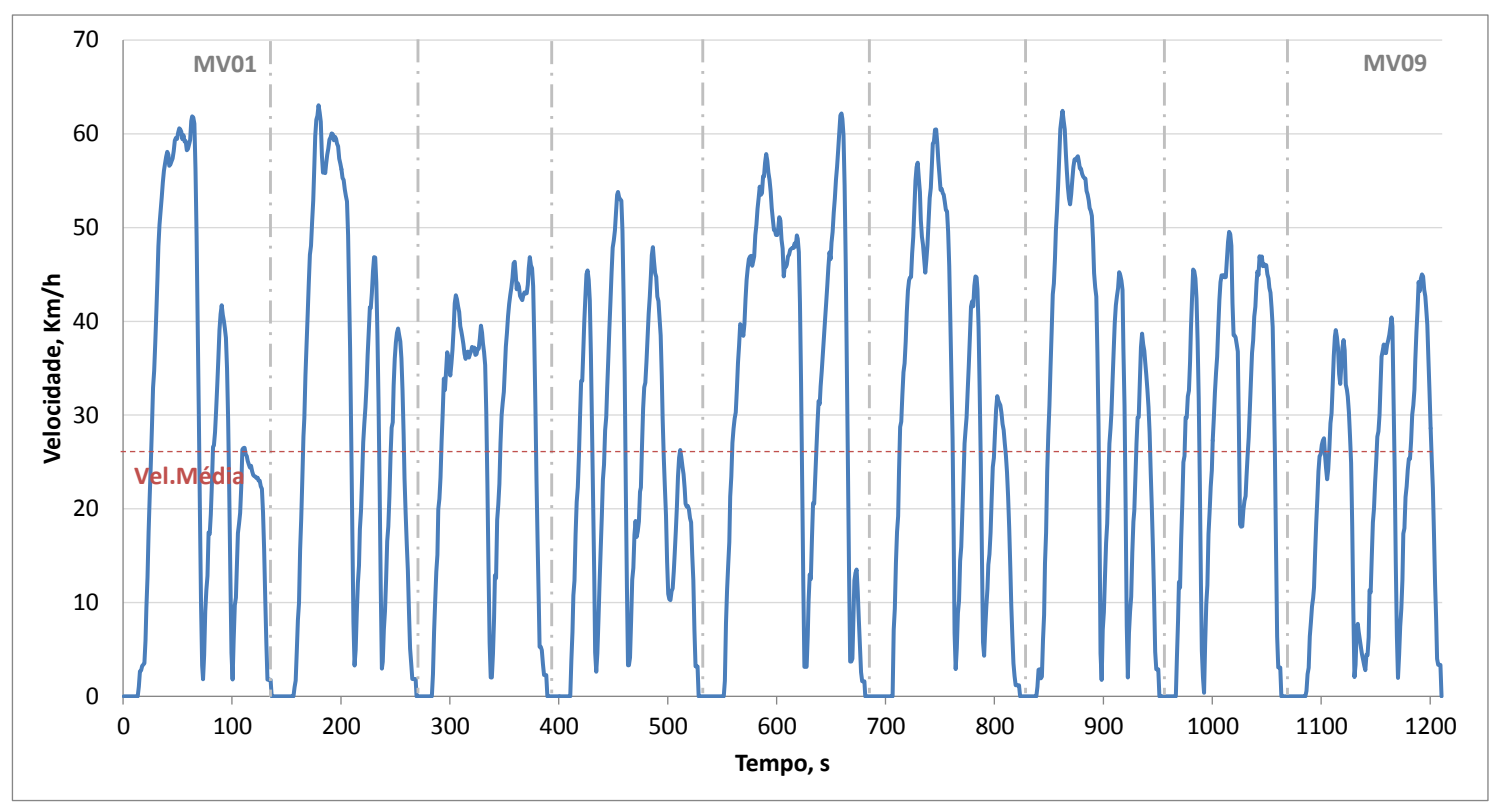

Figura 48 - Ciclo de condução para o trecho $D$ fora dos horários de pico.

Conforme os dados comparativos entre ambos os ciclos, a condição de pico mostra maior variabilidade da velocidade.

Para verificar a representatividade do ciclo em termos de VSP, a Tabela 26 compara as distribuições de VSP para a amostra de dados do trecho $D$ fora do horário de pico e para o ciclo de condução construído para este trecho neste período.

Tabela 26 - Distribuição das faixas de VSP para os horários fora de pico no trecho D, na amostra total e no ciclo construído.

\begin{tabular}{ccc}
\hline Faixas de VSP & Total & Ciclo \\
\hline-20 a 11 & $3,8 \%$ & $5,4 \%$ \\
-10 a 1 & $19,9 \%$ & $18,8 \%$ \\
0 & $26,3 \%$ & $25,8 \%$ \\
1 a 10 & $46,0 \%$ & $45,4 \%$ \\
11 a 20 & $3,6 \%$ & $4,5 \%$ \\
\hline
\end{tabular}




\subsubsection{Trecho E - Avenidas Eng. Armando de Arruda Pereira, Dr. Hugo}

\section{Beolchi, Jabaquara e Rua Domingos de Morais (São Paulo)}

A Figura 49 mostra o trecho $E$, percorrido somente no sentido $A-B$, que foi formado pelas avenidas Engenheiro Armando de Arruda Pereira, Dr. Hugo Beolchi, Jabaquara e rua Domingos de Morais, em São Paulo. Para este trecho foram adquiridos 61.658 segundos de dados (aproximadamente 1028 minutos em 758 microviagens) durante o experimento com veículo de testes.

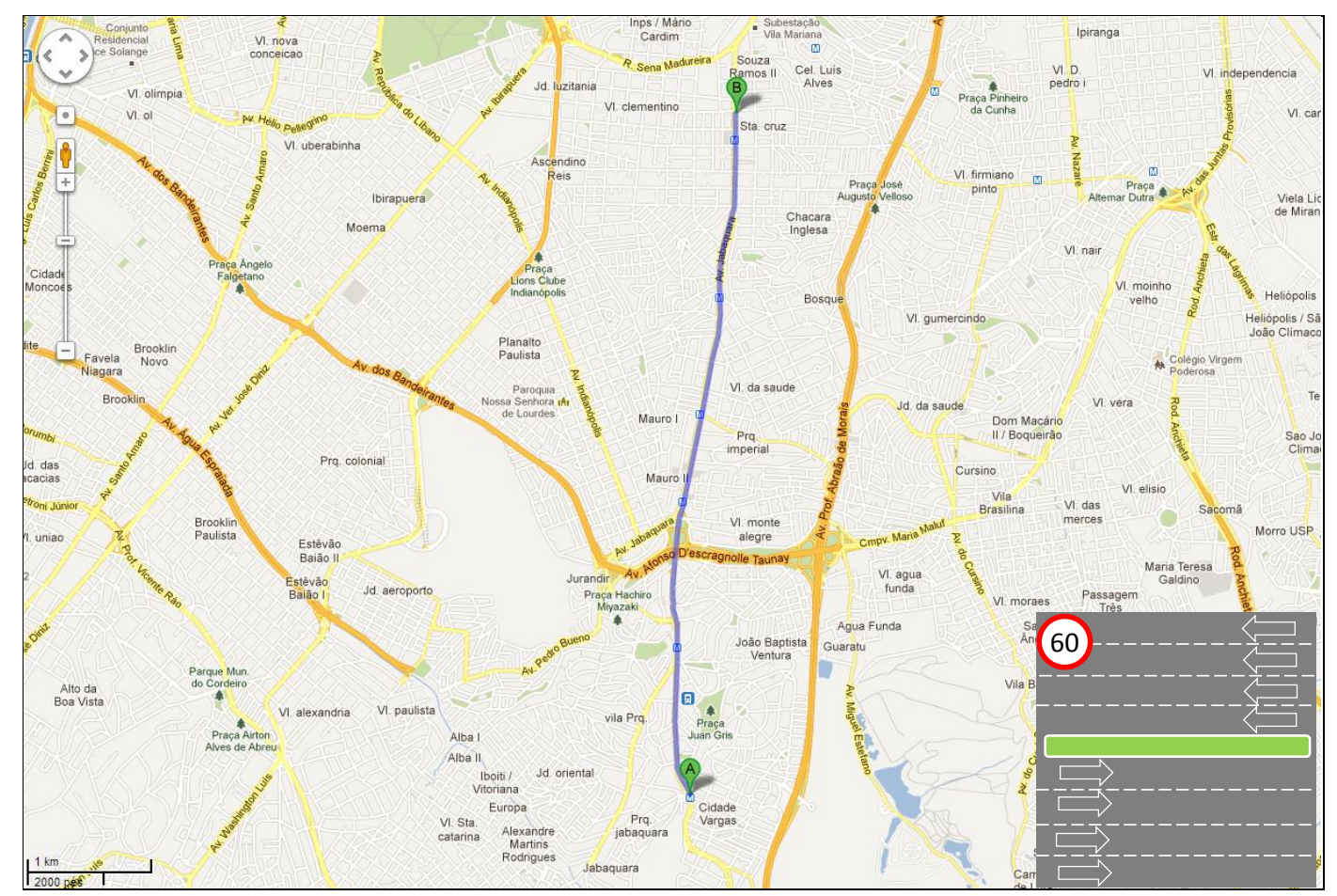

Figura 49 - Trecho E - Av. Engenheiro Armando de Arruda Pereira / Av. Dr. Hugo Beolchi / Av. Jabaquara / R. Domingos de Morais (São Paulo) - Percorrida somente no sentido A-B.

O trajeto é praticamente uma grande avenida de $5,6 \mathrm{~km}$ de extensão, porém com diversos nomes diferentes e que é formado em sua maioria por três e até quatro faixas de rolamento em cada sentido, com separação por canteiro central e velocidade máxima permitida de $60 \mathrm{~km} / \mathrm{h}$. A Figura 50 mostra exemplo de via percorrida no trecho $\mathrm{E}$. 


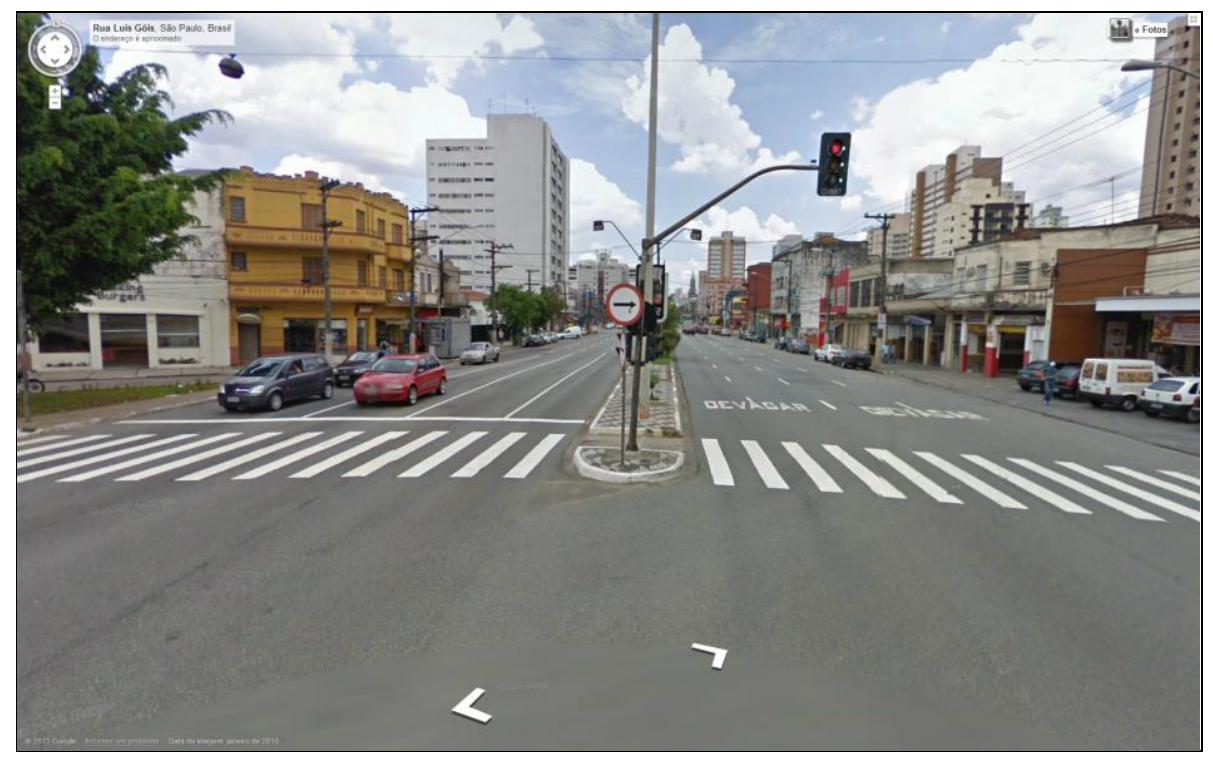

Figura 50 - Imagem da Av. Jabaquara, que compõe o trecho E (Google Street View).

O trecho $\mathrm{E}$ foi percorrido nos horários de pico e fora de pico, que representaram $44,8 \%$ e 55,2\% do total de dados adquiridos respectivamente. Este trecho foi o que apresentou maior diferença entre ambos os horários para os dados básicos de deslocamento e formação das microviagens, mostrando que o tráfego nas vias que compõem o trecho $E$ é provavelmente o que possui a maior variação entre os horários do dia.

Para os horários de pico a velocidade média foi 34,3\% inferior, as microviagens foram $18,5 \%$ mais curtas e observou-se proporcionalmente $37 \%$ a mais de tempo parado em relação aos horários fora do pico. Os dados básicos para essas comparações podem ser verificados na Tabela 27.

Tabela 27 - Indicadores básicos das microviagens do trecho E para horários de pico e fora de pico.

\begin{tabular}{lcccc}
\hline & $\begin{array}{c}\text { Velocidade } \\
\text { Média } \\
\mathrm{km} / \mathrm{h}\end{array}$ & $\begin{array}{c}\text { Duração } \\
\text { média } \\
\text { microviagem }\end{array}$ & \multicolumn{2}{c}{$\begin{array}{c}\text { Tempo parado } \\
\text { médio }\end{array}$} \\
\hline Pico & 9,2 & $\mathrm{~s}$ & $\mathrm{~s}$ & $\%$ \\
\hline Fora Pico & 14,0 & 89,0 & 34,9 & $47,8 \%$ \\
\hline Total Pico e Fora pico & 11,6 & 81,3 & 31,2 & $34,8 \%$ \\
\hline
\end{tabular}

A construção das distribuições de VSP para os horários pico e fora de pico, na Figura 51, mostra que, independente dos horários, o trecho E é o que possui a maior 
concentração de valores de VSP iguais a zero em comparação com os demais trechos do experimento, conforme o comparativo resumido mostrado anteriormente na Tabela 13.

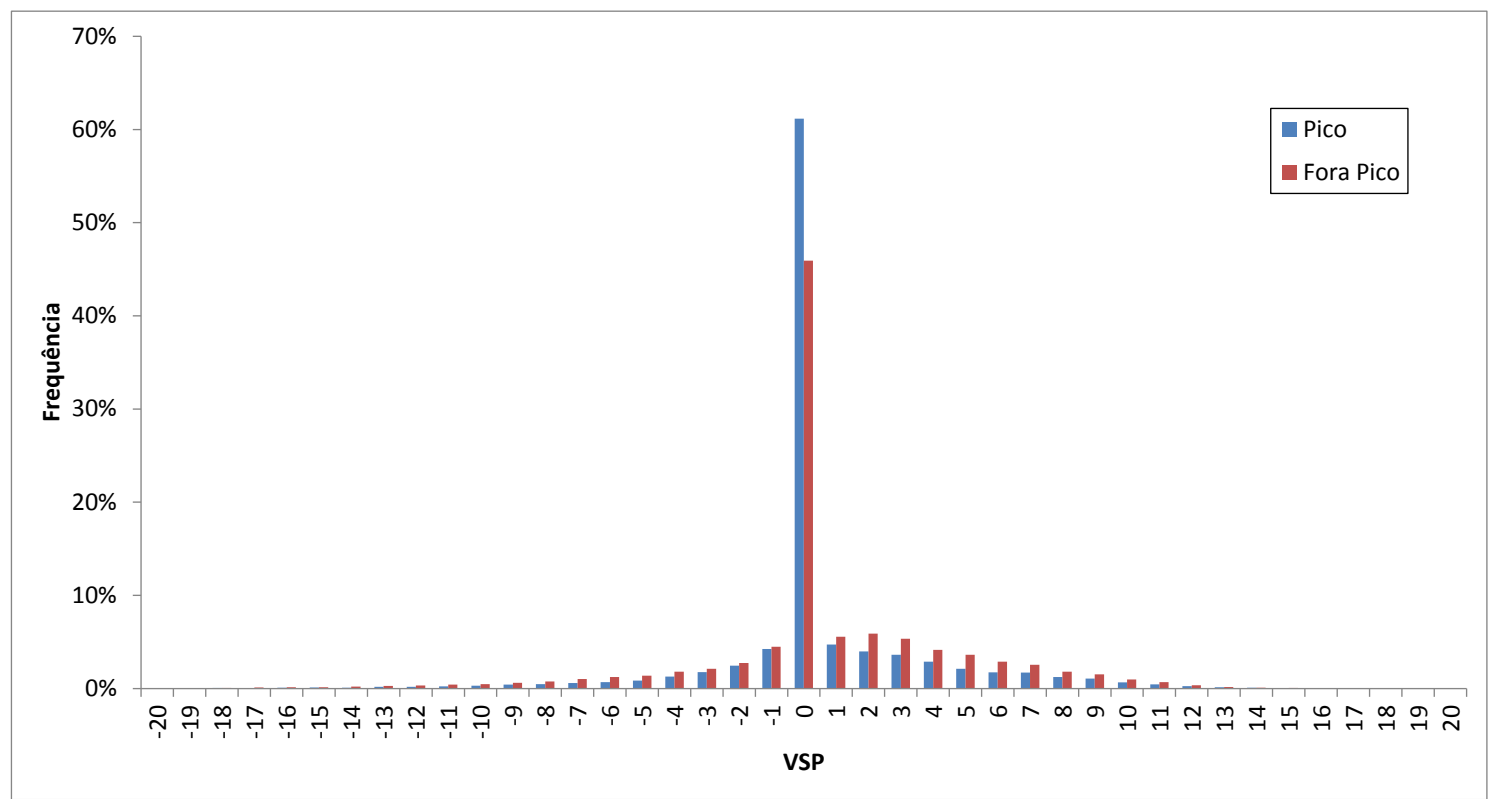

Figura 51 - Distribuição de VSP para o trecho E nos horários de pico e fora de pico.

Além disso, o impacto do tráfego do horário de pico na distribuição de VSP para o trecho $\mathrm{E}$ é o que se destaca mais, resultando em $61 \%$ do tempo valores iguais a zero em comparação aos $46 \%$ na condição fora de pico (redução de $25 \%$ ). Para ambos os períodos o veículo passa tempo equivalente desacelerando $(\mathrm{VSP}<0)$, porém nos horários fora de pico há maior concentração de VSP positivo, o que pode ser verificado na Tabela 28.

Tabela 28 - Distribuição das faixas de VSP para o trecho E nos horários de pico e fora de pico.

\begin{tabular}{ccc}
\hline Faixas de VSP & Pico & Fora Pico \\
\hline-20 a -11 & $1 \%$ & $2 \%$ \\
$-10 a-1$ & $13 \%$ & $17 \%$ \\
& $61 \%$ & $46 \%$ \\
1 a 10 & $24 \%$ & $34 \%$ \\
11 a 20 & $1 \%$ & $1 \%$ \\
\hline
\end{tabular}

As diferenças observadas no deslocamento do veículo de testes para os horários de pico e fora de pico apresentados mostram que existem variações das condições de 
tráfego muito importantes e que justificam a construção de dois ciclos de condução para o trecho $\mathrm{E}$.

\subsubsection{Ciclos de condução para o trecho $E$}

O ciclo de condução para os horários de pico do trecho E, na Figura 52, foi desenvolvido a partir de dez microviagens com duração média de 118 segundos com $54,1 \%$ de proporção de tempo parado, o maior para todos os trechos e períodos analisados neste experimento. A velocidade média foi de $10,1 \pm 13,8 \mathrm{~km} / \mathrm{h}$ (cv $=1,37)$.

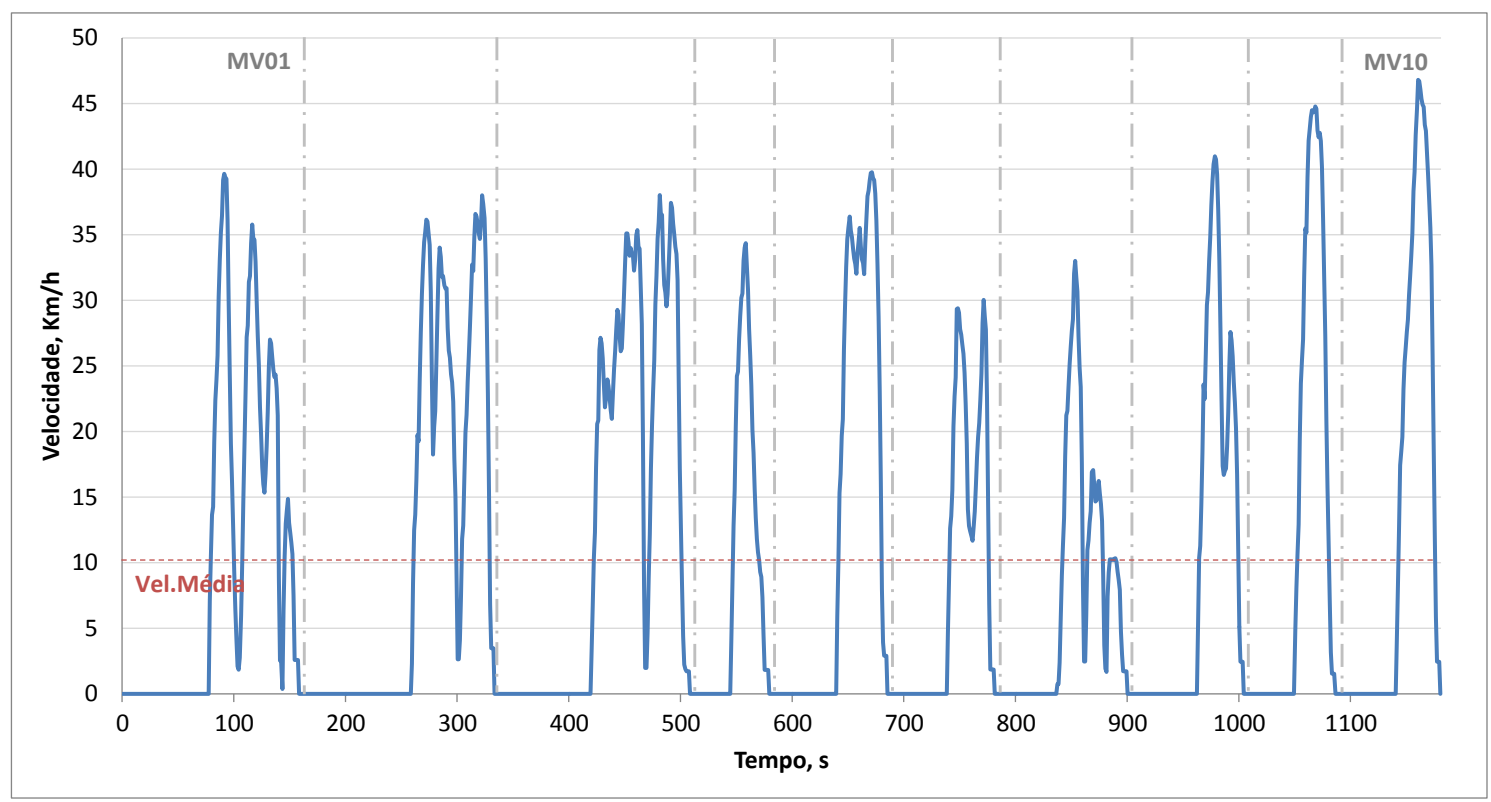

Figura 52 - Ciclo de condução para o trecho E nos horários de pico.

A Tabela 29 mostra a comparação das faixas de VSP para o trecho E nos horários de pico, considerando a amostra total para este trecho e período, e o ciclo construído para essa condição, onde é possível verificar a semelhança dos resultados.

Tabela 29 - Distribuição das faixas de VSP para os horários de pico no trecho E, na amostra total e no ciclo construído.

\begin{tabular}{ccc}
\hline Faixas de VSP & Total & Ciclo \\
\hline-20 a 11 & $1,0 \%$ & $0,4 \%$ \\
-10 a 1 & $13,1 \%$ & $14,7 \%$ \\
0 & $61,2 \%$ & $62,2 \%$ \\
1 a 10 & $23,8 \%$ & $21,8 \%$ \\
11 a 20 & $1,0 \%$ & $0,8 \%$ \\
\hline
\end{tabular}


Para os horários fora de pico, o ciclo de condução mostrado na Figura 53 foi desenvolvido a partir de nove microviagens de duração média de 132 segundos e proporção de tempo parado de $35,5 \%$. A velocidade média desenvolvida foi de 14,9 $\pm 15,4 \mathrm{~km} / \mathrm{h}(\mathrm{cv}=1,03)$.

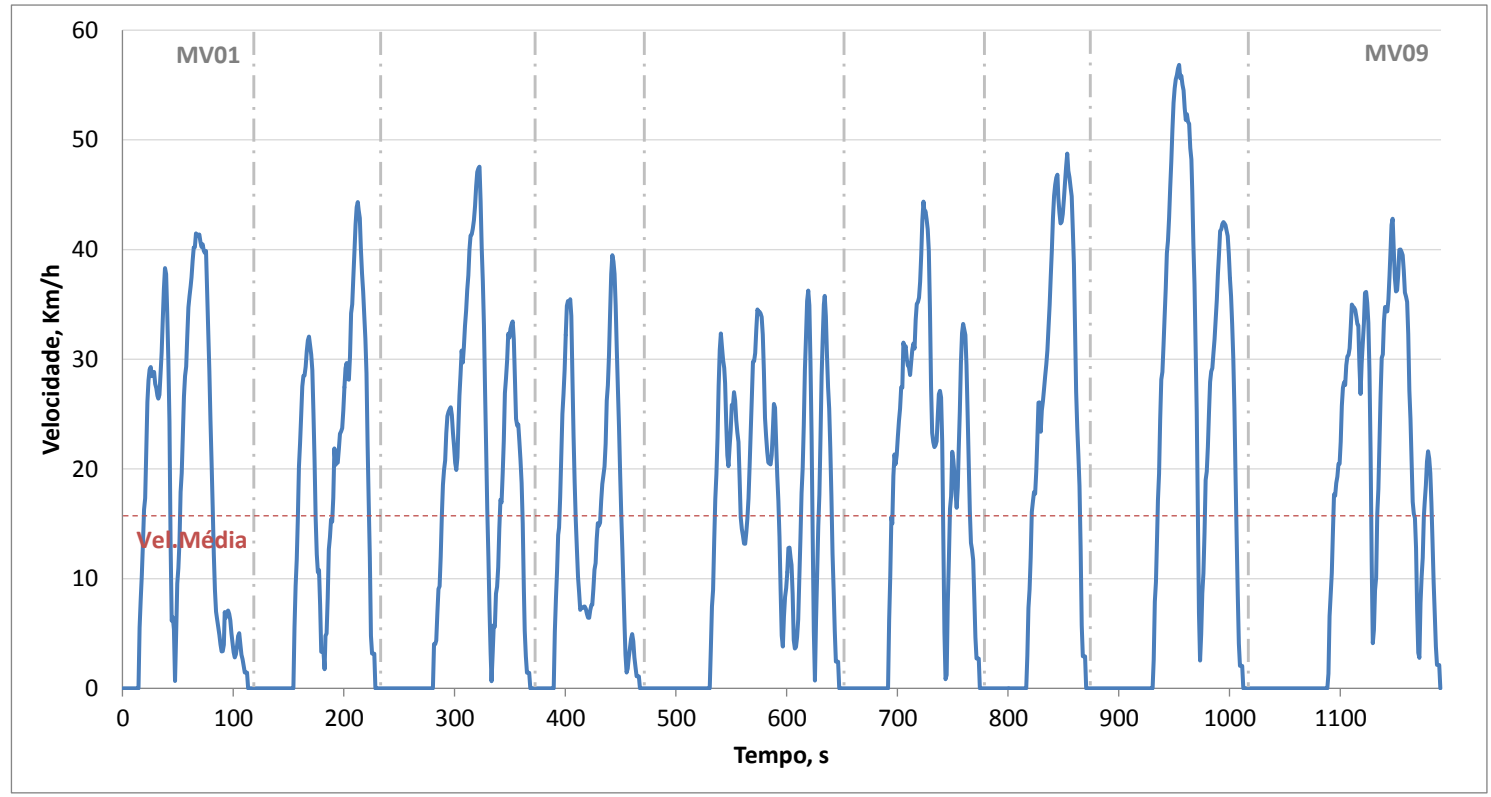

Figura 53 - Ciclo de condução para o trecho E fora dos horários de pico.

A Tabela 30 compara as distribuições de VSP para a amostra de dados do trecho E fora do horário de pico e para o ciclo de condução construído para este período e trecho.

Tabela 30 - Distribuição das faixas de VSP para os horários fora de pico no trecho E, na amostra total e no ciclo construído.

\begin{tabular}{ccc}
\hline Faixas de VSP & Total & Ciclo \\
\hline-20 a 11 & $1,7 \%$ & $1,3 \%$ \\
-10 a 1 & $16,6 \%$ & $18,0 \%$ \\
0 & $45,9 \%$ & $46,9 \%$ \\
1 a 10 & $34,3 \%$ & $32,6 \%$ \\
11 a 20 & $1,4 \%$ & $1,3 \%$ \\
\hline
\end{tabular}




\subsubsection{Síntese dos resultados - Construção dos ciclos de condução}

Apesar da distribuição de VSP para todos os ciclos construídos serem sempre muito semelhantes às bases de cálculo, outros indicadores importantes são em sua maioria negligenciados pelo método de seleção e construção de ciclos de condução proposto por Lai et al. (2012) e aplicado neste trabalho.

Tal fato pode explicado pela seleção das microviagens ocorrer somente baseada na distribuição de VSP. Integrar a distribuição de velocidade e aceleração ao método pode contribuir para a ampliação da similaridade das microviagens em relação a outros indicadores do comportamento dinâmico do veículo.

Em geral, os valores de velocidade e duração média das microviagens selecionadas foram muito diferentes da referência, seja qual for o período ou o trecho analisado. Para os horários de pico, a velocidade média para os ciclos construídos foi de aproximadamente $20,1 \%$ maior do que a amostra total para o trecho e período, enquanto para duração das microviagens e proporção de tempo parado este aumento foi em média de $50,4 \%$ e $21,1 \%$ respectivamente. Os detalhes desta comparação podem ser verificados na Tabela 31. 
Tabela 31 - Comparativo de resultados nos horários de pico para as amostras e ciclos.

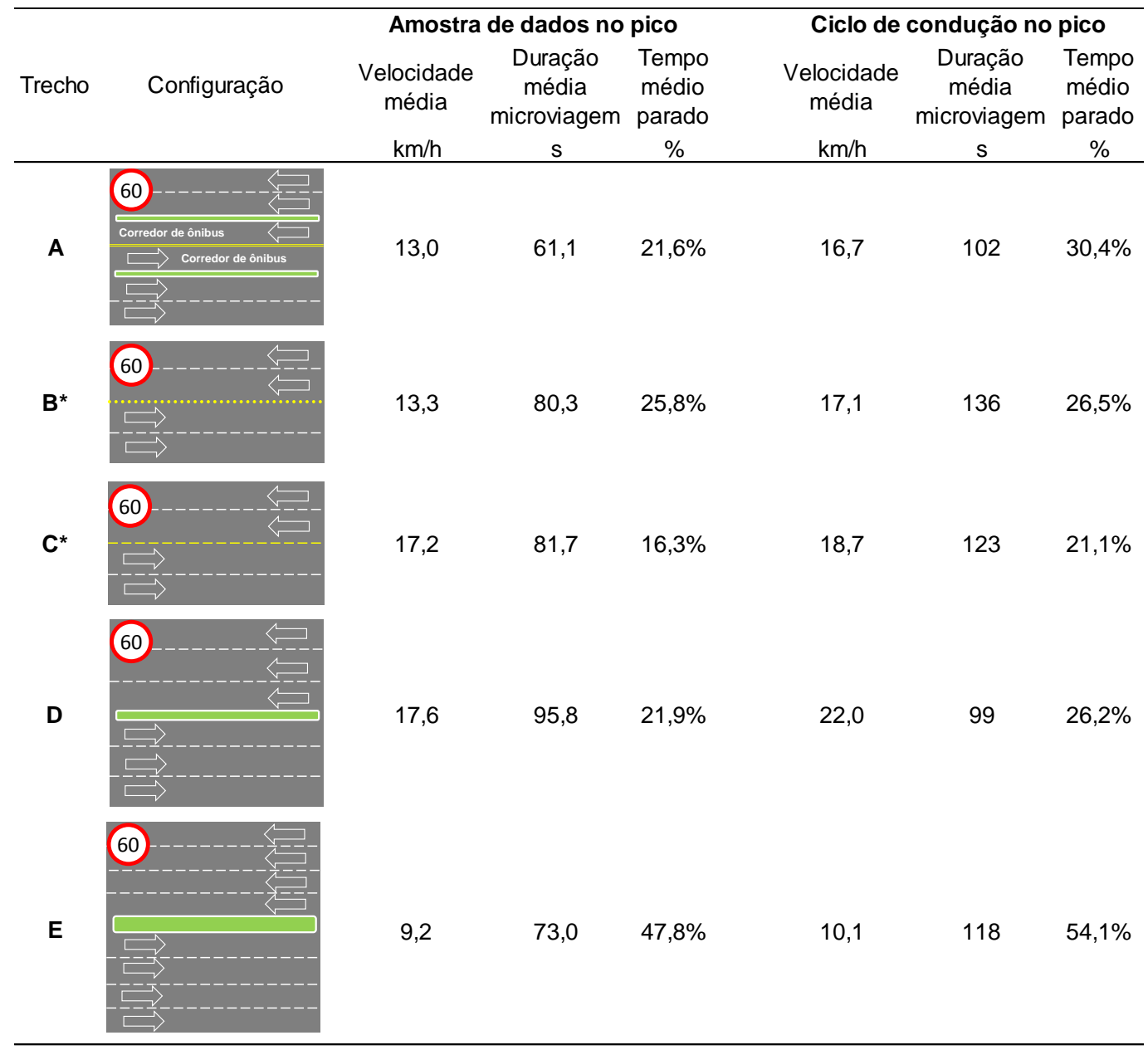

* Somente um ciclo de condução foi desenvolvido, independente do período, devido à semelhança dos resultados do pico e fora do pico

Para a condição fora dos horários de pico, a maior diferença entre a referência e os ciclos construídos também se deu na duração das microviagens, com divergência de $61,5 \%$ em média. Para a velocidade média, a diferença média em relação à amostra total foi de $22,4 \%$ enquanto que o resultado para o tempo médio parado foi o melhor obtido, com uma diferença em média igual a 8,7\%, conforme a Tabela 32. 
Tabela 32 - Comparativo de resultados fora dos horários de pico para as amostras e ciclos.

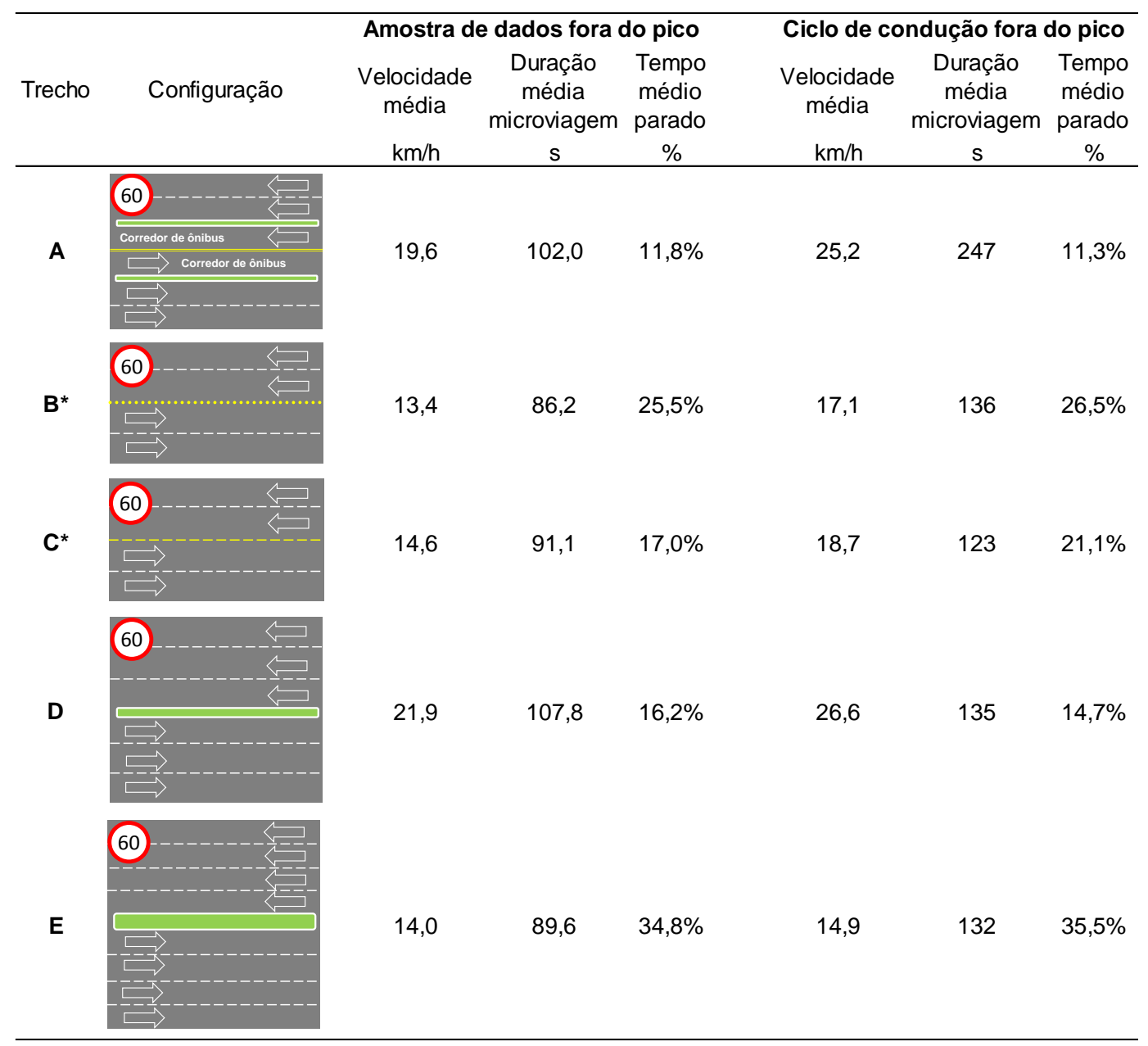

* Somente um ciclo de condução foi desenvolvido, independente do período, devido à semelhança dos resultados do pico e fora do pico

Independente do trecho ou do período do dia, as diferenças encontradas nos indicadores pesquisados, resultantes da construção dos ciclos, não sugerem uma influência direta das características geométricas da via, apesar dos trechos $\mathrm{D}$ e $\mathrm{E}$ terem apresentado proporcionalmente as menores diferenças, provavelmente em função das condições de tráfego mais favoráveis.

Assim, verifica-se que ao priorizar estritamente a distribuição de VSP na escolha das microviagens o método utilizado resulta em valores divergentes para os demais indicadores do deslocamento. No entanto, se a construção de um ciclo de condução for motivada pela estimativa de emissões, os resultados obtidos serão adequados para este fim, uma vez que está mais correlacionada com o VSP do que com as demais variáveis. 


\section{ESTIMATIVA DE EMISSÕES}

Com a conclusão da construção dos ciclos de condução e identificação das distribuições de VSP para os trechos selecionados, foi possível estimar as emissões de poluentes mais relevantes.

$\mathrm{Na}$ estimativa de emissões foram utilizados os fatores de emissões desenvolvidos para o MOVES (Motor Vehicle Emission Simulator - Simulador de emissões de veículos a motor), o sistema de modelagem de emissões de fontes móveis desenvolvido pela agência de proteção ambiental americana (EPA) que possui ampla aceitação no meio acadêmico e na prática profissional, e é a ferramenta oficial da EPA para estimativa de emissões nos Estados Unidos. No MOVES, cada caixa de VSP possui fatores de emissões padronizados para poluentes selecionados de diversos tipos de veículo, de acordo com a tecnologia de redução de emissões e ano de fabricação.

A base de dados para a elaboração das estimativas foi 0 relatório de desenvolvimento de taxas de emissões por veículos pesados para o simulador de emissões MOVES (Development of Emission Rates for Heavy Duty Vehicles in the Motor Vehicle Emissions Simulator, Estados Unidos, 2009). Esse relatório descreve detalhadamente os métodos para aquisição dos fatores de emissões para os principais poluentes produzidos por motores de veículos pesados utilizados no desenvolvimento do MOVES.

O documento mostra as classificações de veículos pesados incluídos no software, baseadas no peso bruto total (PBT), idade e ano-modelo e configuração veicular tais como caminhões MHD (Medium heavy-duty - veículo pesado-médio), HHD (Heavy Heavy-Duty - veículo pesado-pesado) e ônibus urbanos.

De acordo com a combinação desses fatores e das características do deslocamento do veículo, existem valores de emissões que foram originalmente medidos em equipamentos específicos e armazenados no software MOVES para a utilização na estimativa de emissões. 
Segundo o procedimento adotado no MOVES, as variáveis velocidade, VSP e aceleração instantâneas combinadas formam o chamado modo de operação, ao qual estão associadas taxas de emissões de poluentes mais relevantes, de acordo com a classificação do veículo descrita anteriormente. Os modos de operação do MOVES estão apresentados na Tabela 33.

Tabela 33 - Definição dos modos de operação do MOVES, adaptado de Estados Unidos (2009).

\begin{tabular}{|c|c|c|c|c|}
\hline $\begin{array}{l}\text { Modo de } \\
\text { operação }\end{array}$ & Descrição & $\begin{array}{l}\text { VSP } \\
k W / t\end{array}$ & $\begin{array}{c}\text { Velocidade } \\
\qquad \mathrm{km} / \mathrm{h}\end{array}$ & $\begin{array}{c}\text { Aceleração } \\
\mathrm{m} / \mathrm{s}^{2}\end{array}$ \\
\hline 0 & Desacelerando / Freando & & & $\begin{array}{c}a \leq-2 \text { ou } \\
\left(a_{t}, a_{t-1} e a_{t-2}<1\right)\end{array}$ \\
\hline 1 & Parado / Marcha lenta & & $v<1$ & \\
\hline 11 & Locomoção sem esforço & $V S P<0$ & $0 \leq v<40$ & \\
\hline 12 & Cruzeiro/Acelerando & $0 \leq \mathrm{VSP}<3$ & $0 \leq v<40$ & \\
\hline 13 & Cruzeiro/Acelerando & $3 \leq \mathrm{VSP}<6$ & $0 \leq v<40$ & \\
\hline 14 & Cruzeiro/Acelerando & $6 \leq \mathrm{VSP}<9$ & $0 \leq v<40$ & \\
\hline 15 & Cruzeiro/Acelerando & $9 \leq \mathrm{VSP}<12$ & $0 \leq v<40$ & \\
\hline 16 & Cruzeiro/Acelerando & $12 \leq \mathrm{VSP}$ & $0 \leq v<40$ & \\
\hline 21 & Locomoção sem esforço & VSP $<0$ & $40 \leq \mathrm{v}<80$ & \\
\hline 22 & Cruzeiro/Acelerando & $0 \leq \mathrm{VSP}<3$ & $40 \leq v<80$ & \\
\hline 23 & Cruzeiro/Acelerando & $3 \leq \mathrm{VSP}<6$ & $40 \leq v<80$ & \\
\hline 24 & Cruzeiro/Acelerando & $6 \leq \mathrm{VSP}<9$ & $40 \leq v<80$ & \\
\hline 25 & Cruzeiro/Acelerando & $9 \leq \mathrm{VSP}<12$ & $40 \leq v<80$ & \\
\hline 27 & Cruzeiro/Acelerando & $12 \leq \mathrm{VSP}<18$ & $40 \leq v<80$ & \\
\hline 28 & Cruzeiro/Acelerando & $18 \leq \mathrm{VSP}<24$ & $40 \leq v<80$ & \\
\hline 29 & Cruzeiro/Acelerando & $24 \leq \mathrm{VSP}<30$ & $40 \leq v<80$ & \\
\hline 30 & Cruzeiro/Acelerando & $30 \leq \mathrm{VSP}$ & $40 \leq v<80$ & \\
\hline 33 & Cruzeiro/Acelerando & $\mathrm{VSP}<6$ & $80 \leq v$ & \\
\hline 35 & Cruzeiro/Acelerando & $6 \leq \mathrm{VSP}<12$ & $80 \leq v$ & \\
\hline 37 & Cruzeiro/Acelerando & $12 \leq \mathrm{VSP}<18$ & $80 \leq v$ & \\
\hline 38 & Cruzeiro/Acelerando & $18 \leq \mathrm{VSP}<24$ & $80 \leq v$ & \\
\hline 39 & Cruzeiro/Acelerando & $24 \leq \mathrm{VSP}<30$ & $80 \leq v$ & \\
\hline 40 & Cruzeiro/Acelerando & $30 \leq \mathrm{VSP}$ & $80 \leq v$ & \\
\hline
\end{tabular}


O relatório da EPA apresenta para alguns tipos de veículos as taxas de emissões para os poluentes óxidos de nitrogênio (NOx), material particulado com diâmetro médio menor que 2,5 mícrones (MP2.5, soma de carbono elementar (EC) e orgânico(OC)), hidrocarbonetos $(\mathrm{HC})$ e monóxido de carbono (CO). As estimativas de emissões foram realizadas com base nesses resultados.

Os resultados gráficos para as emissões apresentados na Figura 54 foram baseados em ensaios realizados com caminhões MHD, HHD e ônibus urbanos ano-modelo 2002 (padrão EPA'98 de controle de emissões, equivalente ao PROCONVE P5 ou Euro3), com idade entre 0 e 3 anos, com exceção dos valores de material particulado, que foram medidos somente nos veículos HHD de mesmo ano-modelo e idade. O relatório estabelece que para ônibus urbanos ano-modelo 2002, as emissões de material particulado devem ser consideradas como a metade das emissões oriundas de caminhões HHD. 


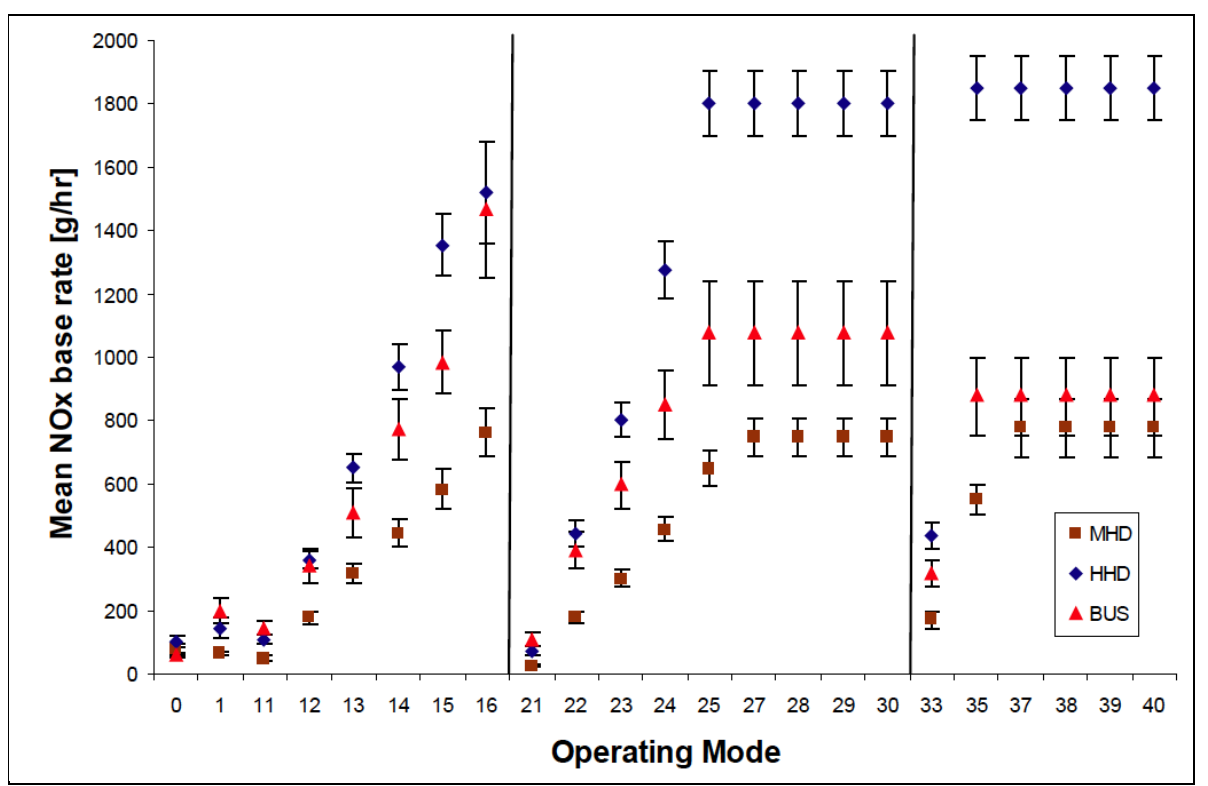

(a)

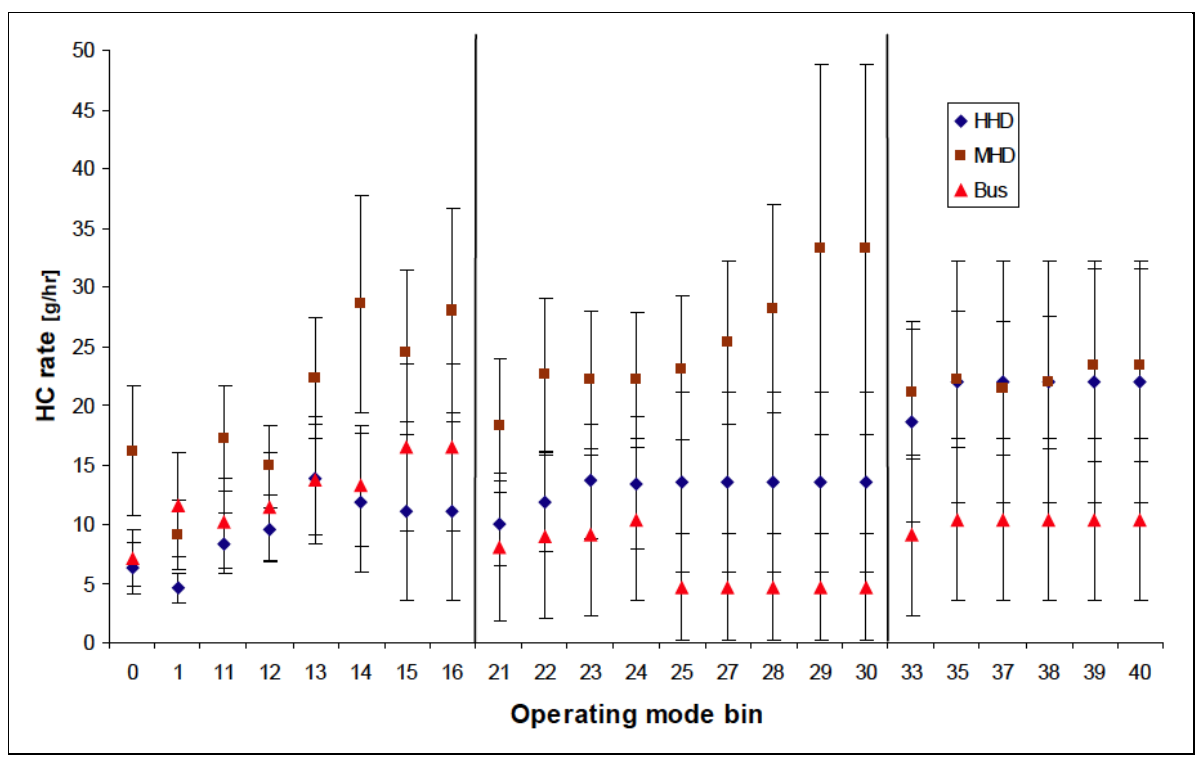

(b)

Figura 54 - Amostras de fatores de emissões em g/h de NOx (a), HC (b), MP2.5 (c) e CO (d) para os modos de operação do MOVES (Estados Unidos, 2009). 


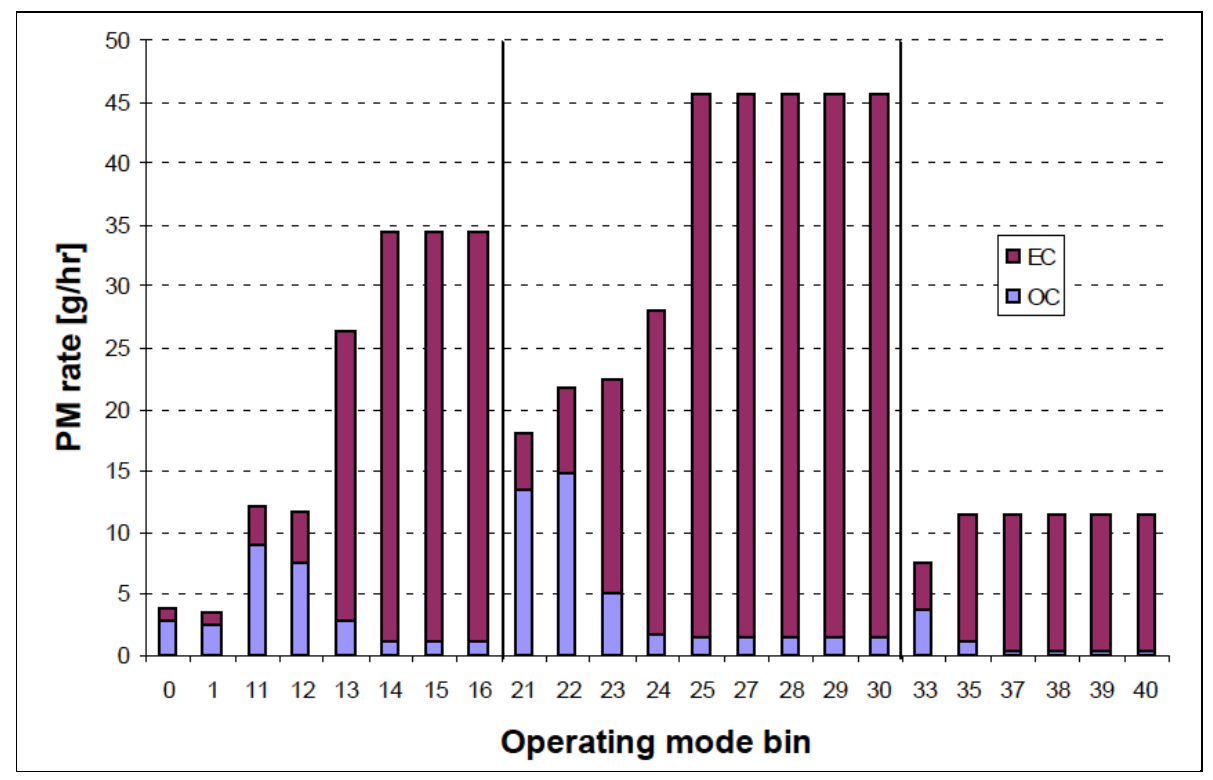

(c)

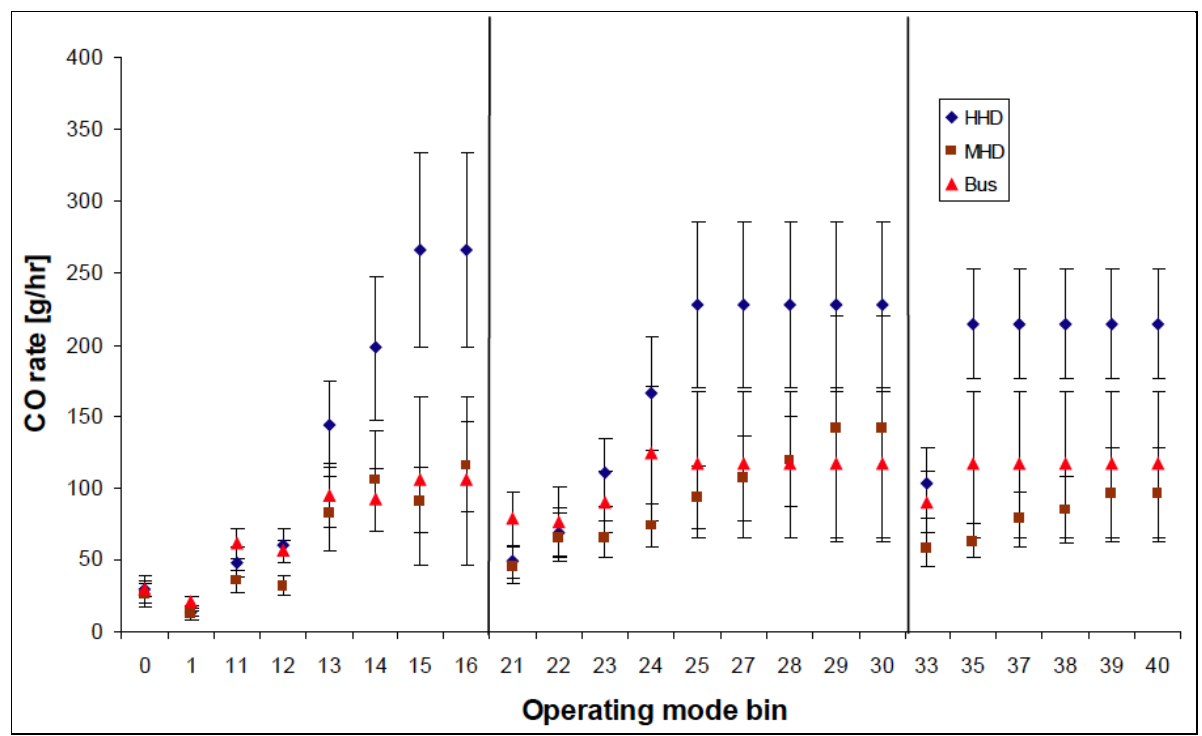

(d)

Figura 53 (cont.) - Amostras de fatores de emissões em g/h de NOx (a), HC (b), MP2.5 (c) e CO (d) para os modos de operação do MOVES (Estados Unidos, 2009).

Com base nos gráficos de emissões apresentados na Figura 54 e nos modos de operação identificados na Tabela 33, foram realizadas as estimativas de emissões para os ciclos de condução desenvolvidos para os trechos de A a E no item 4.3. 


\subsection{ESTIMATIVA DE EMISSÕES PARA OS CICLOS DE CONDUÇÃO DESENVOLVIDOS}

Para possibilitar a estimativa de emissões, foram identificados os modos de operação correspondentes a cada segundo dos ciclos de condução desenvolvidos no item 4.3 conforme apresentado no documento publicado pela EPA (Estados Unidos, 2009). Os resultados podem ser visualizados na Tabela 34.

Tabela 34 - Modos de operação identificados para os ciclos de condução dos trechos A-E.

\begin{tabular}{|c|c|c|c|c|c|c|c|c|}
\hline \multirow{2}{*}{$\begin{array}{l}\text { Modo de } \\
\text { operação }\end{array}$} & \multicolumn{2}{|c|}{ Trecho A } & \multirow[t]{2}{*}{ Trecho B } & \multirow[t]{2}{*}{ Trecho C } & \multicolumn{2}{|c|}{ Trecho D } & \multicolumn{2}{|c|}{ Trecho E } \\
\hline & Pico & $\begin{array}{l}\text { Fora } \\
\text { Pico }\end{array}$ & & & Pico & $\begin{array}{l}\text { Fora } \\
\text { Pico }\end{array}$ & Pico & $\begin{array}{l}\text { Fora } \\
\text { Pico }\end{array}$ \\
\hline 0 & 40 & 92 & 47 & 49 & 41 & 71 & 26 & 32 \\
\hline 1 & 381 & 142 & 302 & 244 & 339 & 181 & 642 & 427 \\
\hline 11 & 180 & 142 & 156 & 196 & 158 & 125 & 146 & 171 \\
\hline 12 & 233 & 249 & 224 & 242 & 176 & 205 & 155 & 244 \\
\hline 13 & 164 & 163 & 143 & 179 & 124 & 121 & 103 & 128 \\
\hline 14 & 68 & 104 & 81 & 84 & 83 & 92 & 57 & 70 \\
\hline 15 & 15 & 43 & 37 & 22 & 26 & 52 & 20 & 27 \\
\hline 16 & 5 & 10 & 5 & 2 & 4 & 7 & 5 & 4 \\
\hline 21 & 33 & 64 & 22 & 22 & 93 & 98 & 7 & 27 \\
\hline 22 & 49 & 72 & 18 & 23 & 76 & 76 & 10 & 19 \\
\hline 23 & 28 & 74 & 20 & 18 & 77 & 60 & 6 & 18 \\
\hline 24 & 9 & 39 & 20 & 13 & 49 & 53 & 1 & 16 \\
\hline 25 & 9 & 25 & 4 & 9 & 27 & 44 & 3 & 5 \\
\hline 27 & 10 & 10 & 10 & 6 & 8 & 25 & 0 & 3 \\
\hline 28 & 1 & 8 & 1 & 0 & 0 & 1 & 0 & 0 \\
\hline 29 & 0 & 3 & 0 & 0 & 0 & 0 & 0 & 0 \\
\hline 30 & 0 & 0 & 0 & 0 & 0 & 0 & 0 & 0 \\
\hline 33 & 0 & 0 & 0 & 0 & 0 & 0 & 0 & 0 \\
\hline 35 & 0 & 0 & 0 & 0 & 0 & 0 & 0 & 0 \\
\hline 37 & 0 & 0 & 0 & 0 & 0 & 0 & 0 & 0 \\
\hline 38 & 0 & 0 & 0 & 0 & 0 & 0 & 0 & 0 \\
\hline 39 & 0 & 0 & 0 & 0 & 0 & 0 & 0 & 0 \\
\hline \multirow[t]{2}{*}{40} & 0 & 0 & 0 & 0 & 0 & 0 & 0 & 0 \\
\hline & 1225 & 1240 & 1090 & 1109 & 1281 & 1211 & 1181 & 1191 \\
\hline
\end{tabular}

Os valores de emissões estão representados nos gráficos da Figura 54 (a-d) como uma taxa em $\mathrm{g} / \mathrm{h}$, porém, para a apresentação das estimativas para os ciclos de 
condução desenvolvidos, os resultados foram convertidos para $\mathrm{g} / \mathrm{km}$, de acordo com a duração e a velocidade média dos ciclos.

\subsubsection{Comparação entre períodos de pico e fora de pico}

Para os ciclos de condução desenvolvidos para o trecho $A$, as emissões estimadas, mostradas na Figura 55, resultaram em valores superiores para todos os poluentes nos períodos de pico em comparação com os períodos fora do pico. O resultado estimado para $\mathrm{HC}$ foi o que obteve a maior diferença entre os períodos, de $36 \%$, enquanto para os demais poluentes a diferença de pico e fora pico variou entre 13,4 e $18,2 \%$.

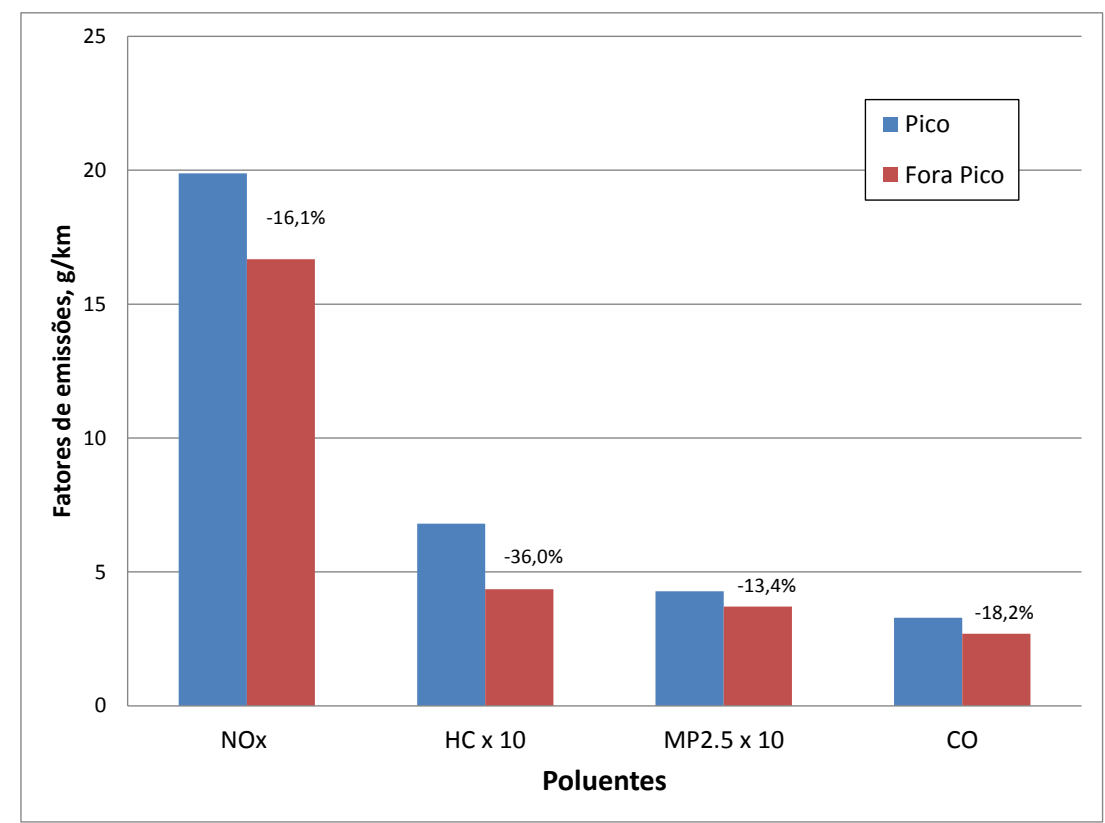

Figura 55 - Estimativa de emissões para os ciclos de condução do trecho A, no pico e fora do pico.

A estimativa de emissões para os ciclos do trecho $D$ resultou em maiores valores para os períodos de pico, de menor velocidade média e maior proporção de tempo parado, com destaque para a diferença na emissão de HC, como mostra a Figura 56. 


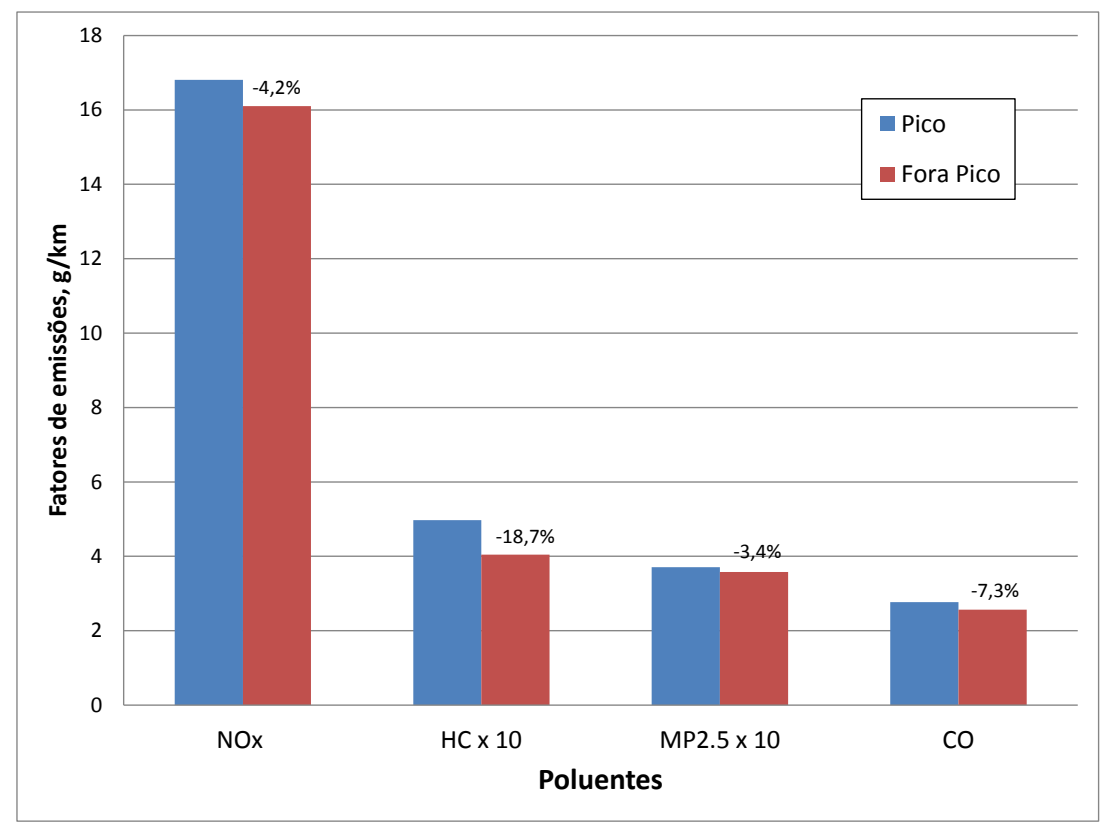

Figura 56 - Estimativa de emissões para os ciclos de condução do trecho D, no pico e fora do pico.

Os ciclos de condução desenvolvidos para o trecho $E$ nos períodos de pico e fora de pico resultaram também em emissões bem diferentes para ambas as situações. $O$ ciclo para a condição fora de pico, com maiores valores de velocidade média e menor variabilidade e menor proporção de tempo parado, obteve um resultado bastante inferior para as emissões em comparação com o ciclo para os períodos de pico. As diferenças mais relevantes entre os dois ciclos foram estimadas para os poluentes NOx $(-22,1 \%)$ e HC (-33\%), conforme a Figura 57.

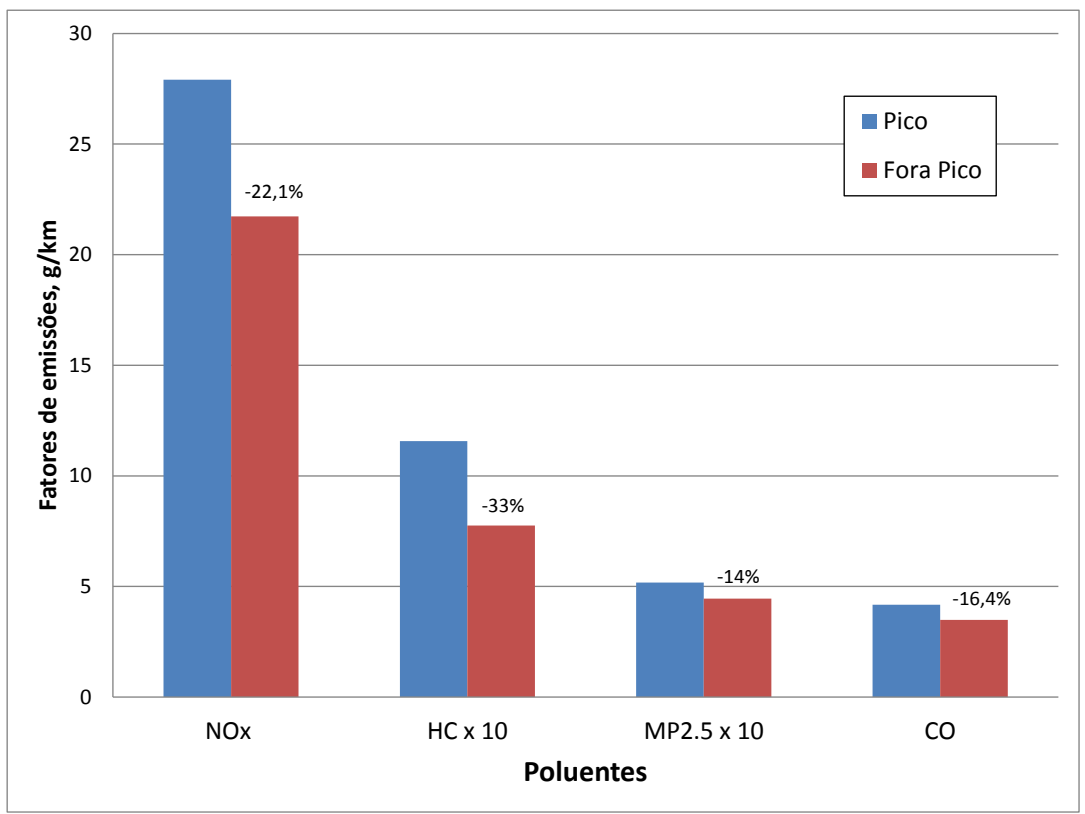

Figura 57 - Estimativa de emissões para os ciclos de condução do trecho E, no pico e fora do pico. 


\subsubsection{Comparação entre trechos}

Para os períodos de pico, os resultados das estimativas de emissões foram, para todos os poluentes verificados, superiores no trecho E, conforme a Figura 58. A maior diferença em relação aos outros ciclos foram verificadas para NOx e HC, podendo indicar que a condição de tráfego pode ter maior impacto nas emissões desses poluentes.

Em média, o trecho $E$ teve emissões $27,1 \%$ superiores em relação ao trecho $A$, e $39,7 \%$ em relação ao trecho $D$. Comparando apenas os trechos $A$ e $D$, o primeiro teve emissões em média aproximadamente $18 \%$ superiores.

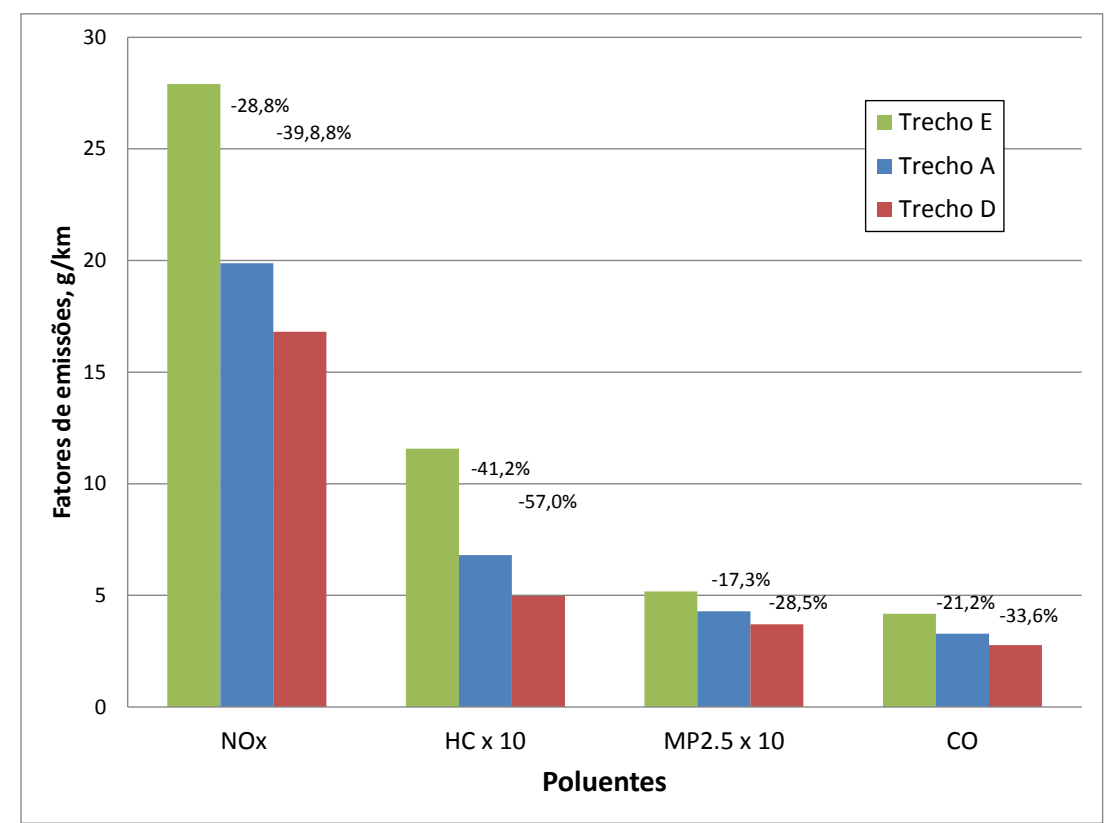

Figura 58 - Estimativa de emissões para os ciclos de condução dos períodos de pico, trechos E, A e D.

Para os trechos nos períodos fora de pico, as emissões estimadas para o trecho $\mathrm{E}$ permaneceram superiores, mas em menor proporção, em relação aos demais trechos comparados, conforme Figura 59. As emissões estimadas para o trecho $\mathrm{E}$ foram em média $26,7 \%$ superiores em comparação ao trecho $A$ e $30 \%$ em relação ao trecho $D$. Entre os trechos $A$ e $D$ a diferença ficou em apenas $4,7 \%$. 


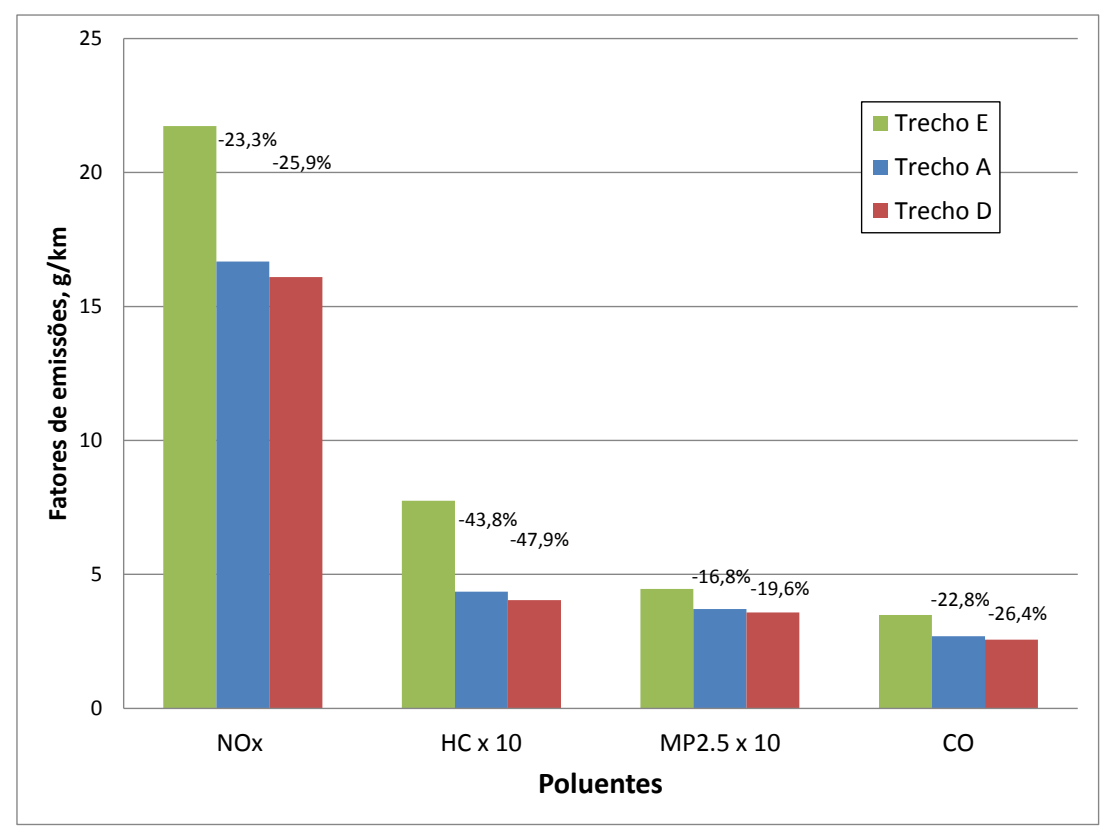

Figura 59 - Estimativa de emissões para os ciclos de condução dos períodos fora do pico, trechos E, A e D.

Os trechos B e C tiveram apenas um ciclo de condução desenvolvido cada. As estimativas de emissões para estes trechos foram agrupadas na Figura 60. 0 ciclo do trecho $\mathrm{C}$, com maior velocidade média, menor coeficiente de variação $\mathrm{e}$ proporção de tempo parado resultou em valores mais reduzidos de emissões de poluentes, em média $7,75 \%$ inferiores àqueles estimados para o ciclo do trecho $\mathrm{B}$.

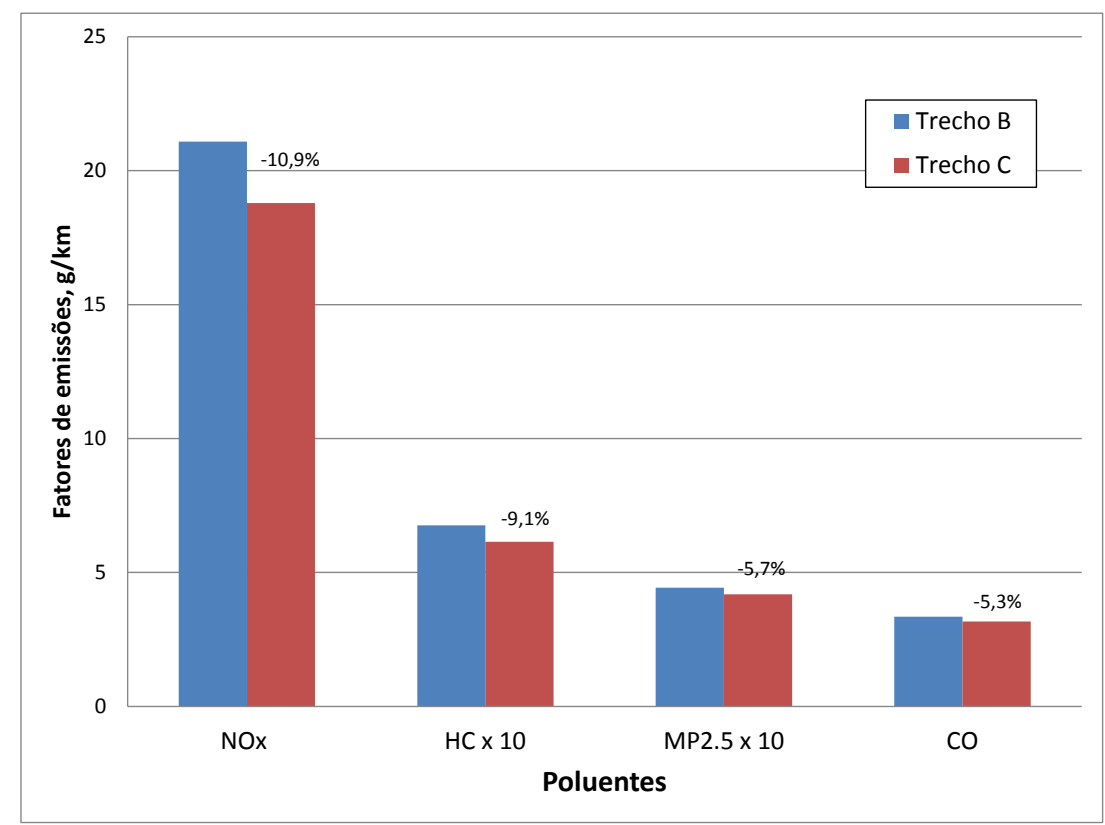

Figura 60 - Estimativa de emissões para os ciclos de condução dos trechos B e C. 
Comparando os valores totais das emissões estimadas (soma dos resultados para NOx, HC, MP2.5 e CO) por trecho e período, com as velocidades médias, verifica-se a forte relação inversamente proporcional entre emissões e a velocidade média, considerando somente trechos de aplicação urbana de paradas constantes. A Figura 61 mostra esse comparativo (eixo vertical, das emissões, em ordem inversa).

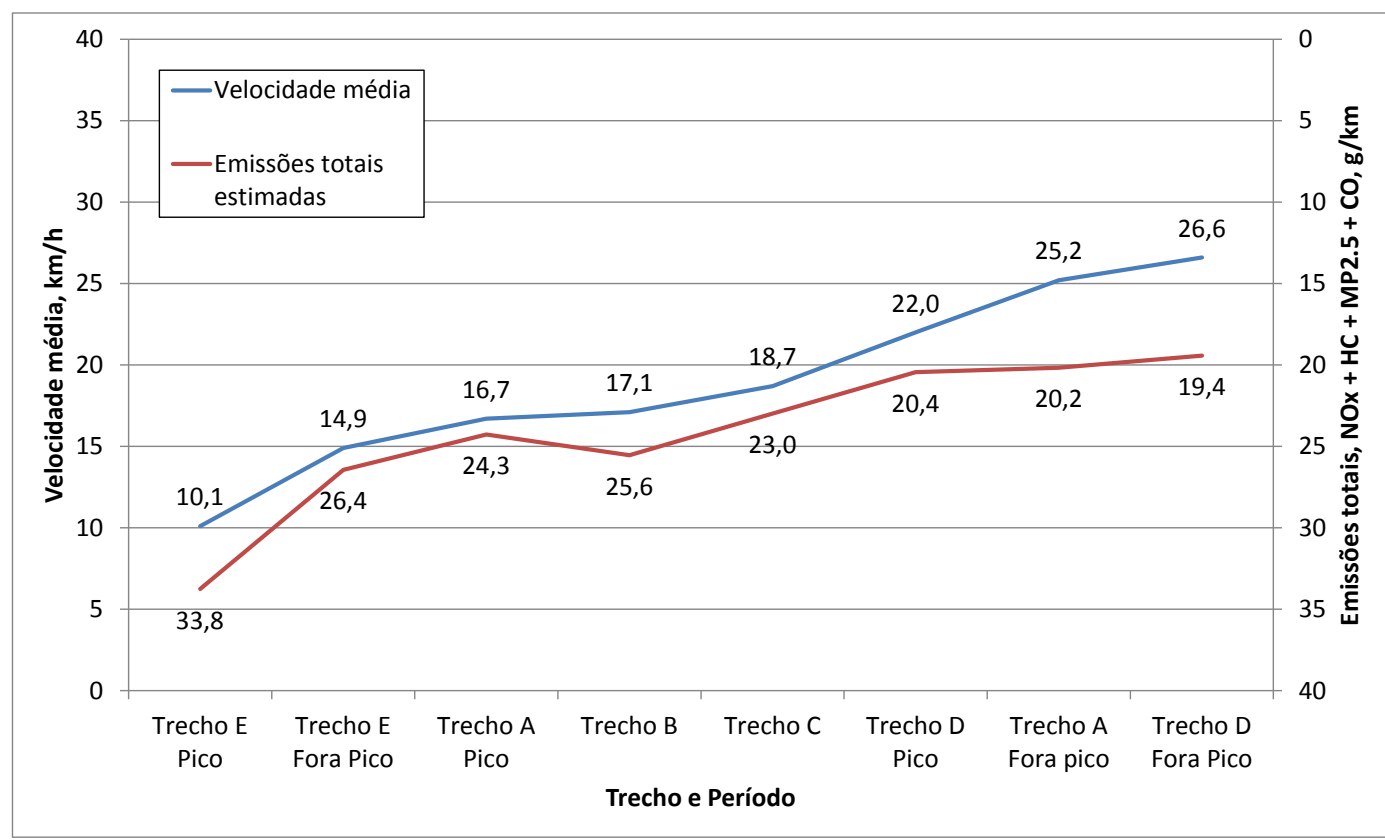

Figura 61 - Comparativo de velocidade média e estimativa de emissões totais para os ciclos de condução desenvolvidos por trecho e período.

A partir dos resultados das estimativas apresentadas nesse capítulo é possível verificar que, invariavelmente, os ciclos de condução com menores velocidades médias e maiores coeficientes de variação, com maior proporção de tempo parado e VSP iguais a zero, resultam em valores mais elevados de emissões de poluentes. 


\section{CONCLUSÃO}

O objetivo principal deste trabalho foi o de construir ciclos de condução que pudessem representar a operação de ônibus urbanos em diferentes tipos de vias e condições de operação, para a estimativa de emissões de poluentes. São raros os esforços semelhantes desenvolvidos no Brasil e o principal estudo realizado para o caso específico dos ônibus urbanos adotou um ciclo de condução que representa condições de operação muito particulares, por tratar-se de circulação em via exclusiva.

Os dados de variação de velocidade ao longo do tempo, necessários para a construção dos ciclos de condução, foram obtidos instrumentando-se um ônibus urbano em testes de durabilidade, que percorreu diversos tipos de vias em um trajeto pré-determinado.

O procedimento para a construção dos ciclos de condução seguiu a metodologia proposta por Lai et al. (2012), que se baseia na similaridade das distribuições de VSP - potência veicular específica - para selecionar microviagens que irão compor os ciclos.

Diversos ciclos de condução foram desenvolvidos, para o percurso completo (com base em aproximadamente 17.640 minutos de observações) e para trechos selecionados de vias, apresentando configurações e condições de tráfego distintas.

Durante o experimento foi possível comparar duas diferentes fontes de aquisição de dados de variação da velocidade: diretamente da central eletrônica do veículo (VCAN) ou através do receptor GPS (VGPS). Para os equipamentos utilizados neste estudo, não havendo interrupções do sinal de GPS, os resultados de velocidade e posteriormente da distribuição de VSP a partir da VGPS divergem pouco em relação aos calculados com base na VCAN, mais precisa.

Desta forma, na realização de experimentos onde se tem acesso aos dados armazenados na ECU do veículo, recomenda-se utilizar a VCAN por sua melhor precisão e menor susceptibilidade à falhas; entretanto, a VGPS pode levar a 
obtenção de resultados com precisão semelhante se o equipamento receptor GPS mantiver boa qualidade de sinal durante a execução das medições de velocidade.

A construção dos diversos ciclos de condução permitiu verificar que a utilização do método de Lai et al. resulta em ciclos com distribuições de VSP bastante semelhantes às que caracterizam a amostra de dados dos quais foram extraídos.

Entretanto, ao privilegiar a distribuição de VSP, o método não reproduziu outros parâmetros que caracterizam os ciclos, tais como velocidade média, duração das microviagens e proporção de tempo parado, cujos resultados foram sistematicamente maiores do que os observados na amostra de dados do qual foram extraídos os ciclos correspondentes. Porém, este fato pode ser relevado se o objetivo da construção do ciclo for estimar emissões, já que esta possui maior correlação com o VSP do que com as demais variáveis.

A construção dos ciclos também permitiu verificar que as condições de tráfego têm importante influência na operação de ônibus urbanos e nas emissões. Em três dos cinco trechos analisados, os resultados de velocidade média, duração das microviagens, proporção de tempo parado e, particularmente, a distribuição de VSP, foram claramente distintos para os períodos de pico e fora do pico.

Foi verificado que trechos e períodos com mais interrupções no deslocamento (por exemplo, maior variabilidade da velocidade e proporção de tempo parado) tendem a resultar em emissões de poluentes mais elevadas. Além disso, verificou-se que, em condições de operação semelhantes, a emissão de poluentes varia de forma inversamente proporcional à velocidade média.

Com isso, é possível verificar a influência da operação nas emissões de poluentes e, assim, sugerir medidas que permitam que os ônibus urbanos circulem com maiores velocidades médias e menor variabilidade da velocidade (como a implantação de corredores e faixas de circulação exclusiva). Além do benefício de melhorar a eficiência e a qualidade do serviço de transporte público, tais modificações podem resultar na diminuição das emissões de poluentes, trazendo benefícios adicionais à sociedade. 


\subsection{RECOMENDAÇÕES DE TRABALHOS FUTUROS}

Os resultados desta dissertação permitem identificar alguns temas que merecem atenção em pesquisas futuras, como os apresentados a seguir:

- do ponto de vista metodológico, é interessante considerar a proposição de métodos de seleção de microviagens que possam melhorar a semelhança entre os ciclos construídos e o conjunto completo de observações também quanto a outros parâmetros, além da distribuição de VSP, como a velocidade média e a proporção de tempo parado;

- para validar o método proposto, podem ser realizadas medições de emissões por ônibus urbanos em condições reais de operação; com esses dados, é possível verificar se as emissões estimadas a partir dos ciclos construídos aproxima-se das medidas em campo;

- quanto à aplicação do método, seria importante que experimento similar ao apresentado neste trabalho fosse conduzido com ônibus urbanos trafegando em faixas e corredores exclusivos, nos quais se espera condições de circulação mais favoráveis do ponto de vista das emissões; estes experimentos deveriam reproduzir também a operação de embarque e desembarque com mais fidelidade. 


\section{REFERÊNCIAS}

ASSOCIAÇÃO BRASILEIRA DE NORMAS TÉCNICAS (ABNT). NBR 15570: transporte - especificações técnicas para fabricação de veículos de características urbanas para transporte coletivo de passageiros. Rio de Janeiro, 2011. 62 p.

ANDREI, P. Real World Heavy-Duty Vehicle Emissions Modeling. Dissertação de Mestrado. Departamento de Engenharia Mecânica e Aeroespacial. Morgantown: The College of Engineering and Mineral Resources, West Virginia University, 2001.

AUSTIN, T.C.; DIGENOVA, F.J.; CARLSON, T.R.; JOY, R.W., GIANOLINI K.A. e LEE, J.M. Characterization of Driving Patterns and Emissions from Light-Duty Vehicles in California: The final report, Contract $n^{\circ}$ A932-185. Sacramento: California Air Resources Board, 1993.

ANDRÉ, M.; HICKMAN, A.; HASSEL, D.; JOURNARD, R. Driving Cycles for Emissions Measurements under European Conditions. SAE Technical Paper 950926. Warrendale: SAE Publications, 1995.

ANDRÉ, M. The ARTEMIS European Driving Cycles for Measuring Car Pollutant Emissions. Science of The Total Environment. №73. Elsevier, p.334-335, 2004.

BARTH, M.; AN, F.; NORBECK, J.; ROSS, M.; Modal Emissions Modeling: A physical approach. Transportation Research Record. № 1520. Washington D.C., p.81-88, 1996.

BRASIL. Ministério do Meio Ambiente - Secretaria de Mudanças Climáticas e Qualidade Ambiental. 1 Inventário nacional de emissões atmosféricas por veículos automotores rodoviários: Relatório final. Brasília, 2011.

CARLSON, T. R. e AUSTIN, T. C. Development of Speed Correction Cycles. Sacramento: Sierra Research Inc., 1997.

CLARK, N.; ERKKILÄ, K.; NYLUND, N.; RIDEOUT, G. Evaluation of Duty Cycles for Heavy-Duty Urban Vehicles. Final Report of IEA AMF Annex XXIX. Espoo: VTT Tiedotteita, 2007.

DAI, Z.; NIEMEIER, D.; EISINGER, D. Driving cycles: A new Cycle-Building Method that Better Represents Real World Emissions. Davis: Department of Civil \& Environmental Engineering, University of California, 2008. 
DIESELNET. Diesel Emissions Online. Disponível em: http://www.dieselnet.com. Acesso em 05 mar. 2012.

ESTADOS UNIDOS. Development of Emissions Rates for Heavy-Duty Vehicles in the Motor Vehicle Emissions Simulator (Draft MOVES2009). Washington D.C.: Environmental Protection Agency - Office of Transportation and Air Quality Assessment and Standards Division, 2009.

FRANCO, V., KOUSOULIDOU, M., MUNTEAN, M., NTZIACHRISTOS, L., HAUSBERGER, S., PANAGIOTA, D. Road vehicle emission factors development: A review. Atmospheric Environment, 70, p.84-97, 2013.

GOOGLE STREET VIEW. Serviço gratuito de pesquisa e visualização de mapas e imagens de satélite da Terra. Disponível em: http://maps.google.com.br, acesso em 15 de março de 2013.

INSTITUTO DE PESQUISAS TECNOLÓGICAS (IPT). Relatório técnico no 91.377205: Ensaios comparativos de ônibus urbanos. São Paulo, 2007.

JIMENEZ-PALACIOS, J.L. Understanding and Quantifying Motor Vehicle Emissions with Vehicle Specific Power and TILDAS Remote Sensing. Tese de doutorado. Departamento de Engenharia Mecânica. Cambridge: Massachusetts Institute of Technology, 1999.

LAI, J., YU, L., SONG, G., GUO, P., CHEN, X. Development of city-specific driving cycles for transit buses based on VSP distributions. $91^{\text {th }}$ Transportation Research Board Annual Meeting. Washington D.C., 2012.

LÓPEZ, M.L., JIMÉNEZ F., APARICIO, F., FLORES, N. On-road emissions from urban buses with SCR + urea and EGR + DPF systems using diesel and biodiesel. Transportation Research Part D, 14, p.1-5, 2009.

LIN, J., NIEMEIER, D.A. An Exploratory Analysis Comparing a Stochastic Driving Cycle to California's Regulatory Cycle. Atmospheric Environment, 36, p.57595770, 2002.

MAJEWSKI, W.A., KHAIR, M.K. Diesel Emissions and Their Control. Warrendale: SAE Publications, 2006.

NESAMANI, K.S., SUBRAMANIAN, K.P. Development of a driving cycle for intra-city buses in Chennai, India. Atmospheric Environment, 45, p.5469-5476, 2011. 
RACELOGIC. Vehicle CAN Bus Interface RLVBCAN02, Instruction Manual. Disponível em http://www.racelogic.co.uk, 2012. Acesso em 14 jan. 2013.

.VB2SX 20Hz GPS Data Logger User Guide. Disponível em http://www.racelogic.co.uk, 2012. Acesso em 14 jan. 2013.

SOCIETY OF AUTOMOTIVE ENGINEERS (SAE). SAE J2711, Recommended Practice for Measuring Fuel Economy and Emissions of Hybrid-electric and conventional Heavy-duty Vehicles. Warrendale: SAE Publications, 2002

TSOLAKIS, A., MEGARITIS, A. Catalytic Exhaust Gas Fuel Reforming for Diesel Engines: Effects of Water Addition on Hydrogen Production and Fuel Conversion Efficiency. International Journal of Hydrogen Energy, 29, p1404-1419, 2004.

ZHAI, H., FREY, H.C., ROUPHAIL, N.M. A Vehicle-Specific Power Approach to Speed- and Facility-Specific Emissions Estimates for Diesel Transit Buses. Environment Science Technology, 42, p.7985-7991, 2008. 